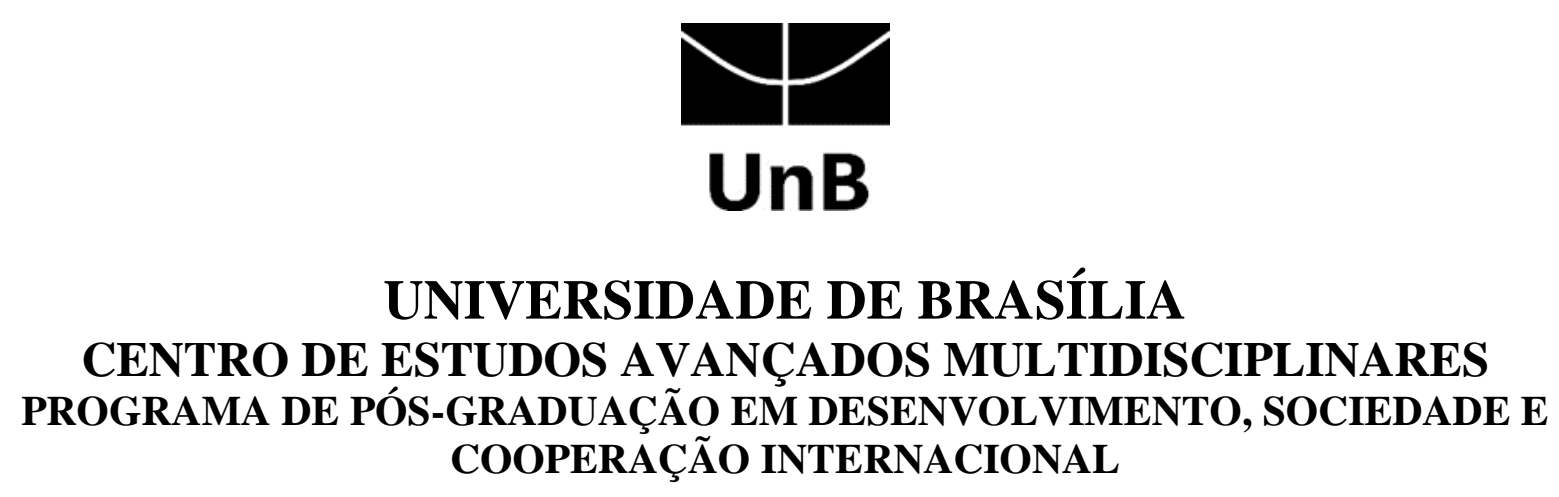

BRUNO HENRIQUE RODRIGUES DE MELO

DESENVOLVIMENTO E POLÍTICAS CULTURAIS DE BASE COMUNITÁRIA NA AMÉRICA DO SUL:

ESTUDO COMPARADO BRASIL-ARGENTINA

Brasília - DF

2016 
BRUNO HENRIQUE RODRIGUES DE MELO

\section{DESENVOLVIMENTO E POLÍTICAS CULTURAIS DE BASE COMUNITÁRIA NA AMÉRICA DO SUL: \\ ESTUDO COMPARADO BRASIL-ARGENTINA}

Dissertação apresentada ao Programa de Pós-Graduação em Desenvolvimento, Sociedade e Cooperação Internacional, do Centro Avançado de Estudos Multidisciplinares, da Universidade de Brasília, como requisito para obtenção do grau de Mestre.

Área de concentração: Desenvolvimento, Sociedade e Cooperação Internacional

Linha de pesquisa: Desenvolvimento e políticas públicas

Orientadora: Prof. ${ }^{a}$ Dr. ${ }^{\text {a }}$ Maria de Fátima Rodrigues Makiuchi

Brasília, DF

2016 


\section{FICHA CATALOGRÁFICA}

Elaborada automaticamente, com os dados fornecidos pelo autor

Ferramenta online: 〈http://www.bce.unb.br/ficha/index.php $>$

MM528d

Melo, Bruno Henrique Rodrigues de

Desenvolvimento e Políticas Culturais de Base

Comunitária na América do Sul: Estudo Comparado

Brasil-Argentina / Bruno Henrique Rodrigues de Melo;

orientador Maria de Fátima Rodrigues Makiuchi. --

Brasilia, 2016.

$152 \mathrm{p}$.

Dissertação (Mestrado - Mestrado em Desenvolvimento, Sociedade e Cooperação

Internacional) -- Universidade de Brasília, 2016.

1. Cultura. 2. Política Cultural. 3.

Desenvolvimento. 4. Políticas Públicas. 5.

Instrumentos de Gestão. I. Makiuchi, Maria de Fátima Rodrigues, orient. II. Título. 


\title{
DESENVOLVIMENTO E POLÍTICAS CULTURAIS DE BASE COMUNITÁRIA NA AMÉRICA DO SUL: ESTUDO COMPARADO BRASIL-ARGENTINA
}

Dissertação apresentada como requisito parcial para obtenção do grau de Mestre em Desenvolvimento, Sociedade e Cooperação Internacional.

Brasília, 31 de março de 2016.

\section{COMISSÃO EXAMINADORA}

Prof. ${ }^{a}$ Dr. ${ }^{a}$ Maria de Fátima Rodrigues Makiuchi

Orientadora - Universidade de Brasília

\author{
Prof. Dra. Lia Calabre
}

Examinadora Externa - Fundação Casa de Rui Barbosa

Prof. ${ }^{a}$ Dr. ${ }^{a}$ Magda de Lima Lúcio

Examinadora Interna - Universidade de Brasília

Prof. ${ }^{a}$ Dr. ${ }^{a}$ Doriana Daroit

Examinadora Suplente - Universidade de Brasília 
A

Daniele, Luís Henrique e Rafael, meus amores, pelo apoio incondicional nessa caminhada. 


\section{AGRADECIMENTOS}

Este é o fim de uma caminhada e o começo de uma nova etapa. Não poderia deixar de agradecer a quem de alguma forma me ajudou nesse percurso de aprendizado, cada um a sua maneira e na medida de suas possibilidades.

À minha esposa Daniele e meus filhos Luís Henrique e Rafael, meus anjos-da-guarda, maior estímulo da vida, por entenderem meu momento e me acompanharem nas agústias e nas vitórias durante todo o mestrado. Abdicaram da minha presença em tantas ocasiões, sempre com o apoio incondicional. À Dani, ainda, pela ajuda na revisão do texto.

Aos meus pais, irmãos e demais familiares que sempre me estimularam a crescer.

À Profa. Fátima Makiuchi, orientadora exemplar, pela paciência, cumplicidade e estímulo, e principalmente por acreditar em mim e na livre troca de ideias.

Ao Ministro Juca Ferreira, pela compreensão e estímulo, e a todos os colegas do Ministério da Cultura que me apoiaram nessa empreitada. Em especial, Ângela Inácio, Gabriel Portela e equipe do Gabinete.

A tantos amigos que ajudaram com trocas de ideias, revisões de texto e discussões estimulantes, em especial Marco Acco, Armando Almeida, Valéria Graziano, Alexandre Caixeta, Eduardo Coelho, Igor de Miranda, Elisabeth Silva, Cleide Vilela, Leandro Carvalho, Fred Maia, Marielle Ramires, Regina Lima, Fabiano dos Santos e Jéferson Assumção.

A todos os demais colegas e colaboradores dos Ministérios da Cultura do Brasil e da Argentina que apoiaram nas entrevistas e com dados para a pesquisa, em especial Alexandre Santini, Isabelle Albuquerque, Ivana Bentes, Cláudia Schulz, Giselle Dupin, Elaine Santos, Márcia Rollemberg, Cleômenes Batista, Diego Benhabib, Ezequiel Gerez, María del Valle Aguilar, Lidia Figueroa, Monica Guariglio.

E aos representantes da Asociación de Mujeres "La Colmena" e do Centro Social y Cultural "Patas Arriba", que gentilmente compartilharam comigo suas experiências com o programa Puntos de Cultura. 
"A democracia é o método de organização pelo qual a sociedade confere continuamente o sentido do desenvolvimento, os seus fins últimos."

(HERRLEIN JR., 2014: p. 89)

"And a good creative person is well trained. So he has first of all an enormous amount of knowledge in that field. Secondly, he tries to combine ideas, because he enjoys writing music or enjoys inventing. And finally, he has the judgment to say, 'This is good, I'll pursue this further'."

Jacob RABINOW, inventor do mecanismo de sintonia fina/Pat US3119273 A

(RABINOW apud CSIKZSENTMIHALYI, 1996: p. 50) 


\section{Resumo}

Esta dissertação apresenta estudo comparado sobre as políticas culturais de base comunitária no Brasil e na Argentina, a partir de uma reflexão sobre os desafios contemporâneos da relação entre cultura, desenvolvimento e cidadania, bem como de uma análise das trajetórias do programas "Cultura Viva" (Brasil) e "Puntos de Cultura" (Argentina). A pesquisa, de caráter interdisciplinar, aborda as especificidades da implementação de políticas públicas similares em contextos diferentes, considerando as influências dos distintos atores, arranjos institucionais e instrumentos de gestão, bem como as novas capacidades estatais necessárias para lidar com essa complexidade. O capítulo 1 apresenta ensaio teórico sobre os desafios contemporâneos envolvendo cultura, desenvolvimento e cidadania à luz dos debates da teoria social sobre a modernidade tardia e diferentes abordagens sobre desenvolvimento e pós-desenvolvimento. O capítulo 2 analisa as trajetórias dos referidos programas nos dois países, com ênfase nos instrumentos de gestão e os desafios da relação Estado - sociedade civil. O capítulo 3 apresenta uma análise comparada Brasil - Argentina, a partir da aplicação do Modelo de Análise Sintonia Fina (MSF), elaborado pelo autor a partir de reflexões sobre as abordagens de arranjos institucionais e capacidades estatais, da teoria do ator-rede e da Sociologia da Ação Pública. As conclusões apresentam os principais achados da pesquisa, à luz da análise comparada Brasil-Argentina, buscando apontar em que medida os elementos constitutivos das políticas culturais e os instrumentos de gestão utilizados contribuem para a construção de capacidades estatais para o desenvolvimento, apoiando-se nos referenciais teóricos e ferramentas de análise apresentados.

Palavras-chave: Políticas Culturais. Cidadania. Direitos Culturais. Desenvolvimento. Participação Social. Instrumentos de Gestão. Arranjos institucionais. Capacidades Estatais. Sociologia da Ação Pública. Brasil. Argentina. Cultura Viva. Pontos de Cultura.

\section{Abstract}

This dissertation presents a comparative study of community-based cultural policies in Brazil and Argentina, analysing the path followed by their respective programmes "Living Culture" (Cultura Viva, Brazil) and "Culture Points" (Puntos de Cultura, Argentina), founded on the analysis of contemporary issues and challenges over the relationship between culture, development, and citizenship. As an interdisciplinary research, it approaches the specificities of implementing similar public policies in distinct contexts, considering the influence of the various actors, institutional arrangements and management instruments, as well as observing the new state capacities that are needed to face this complexity. Chapter One is a theoretical essay over the contemporary challenges involving culture, development, and citizenship, in light of the social theory debates over late modernity and different approaches to development and post-development. Chapter Two analyses the respective programme paths in both countries, focusing on management instruments and the major issues over the relation between State and civil society. Chapter Three presents a Brazil - Argentina comparative analysis, applying the Fine Tuning Model (FTM) conceptual framework which was designed by this author, based on the study of different approaches such as institutional arrangements, state capacities, actor-network theory and Sociology of Public Action. The conclusions present the main findings of the research from a comparative perspective, attempting to indicate the extent to which the core elements of cultural policy and management instruments contribute to development and to the building of state capacities, based on the theories and tools of analysis that were studied.

Keywords: Cultural Policy. Citizenship. Cultural Rights. Development. Social Participation. Management Instruments. Institutional Arrangements. State Capacities. Sociology of Public Action. Brazil. Argentina. Living Culture. Culture Hotspots. 


\section{LISTA DE TABELAS}

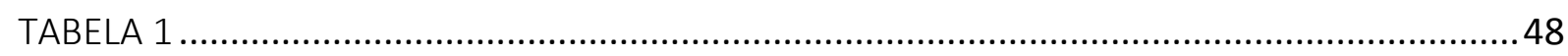

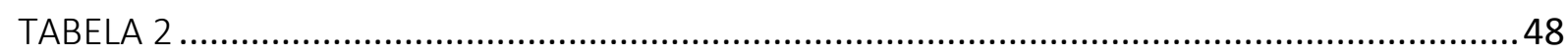

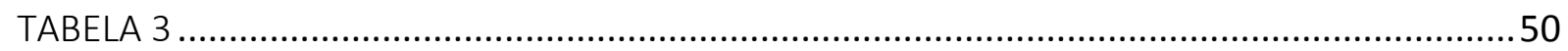

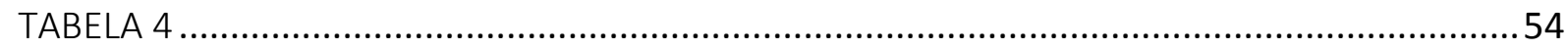

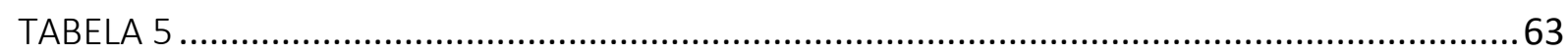

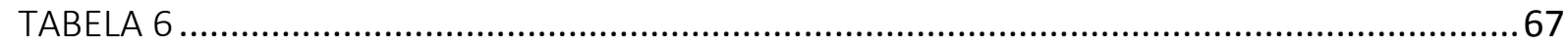

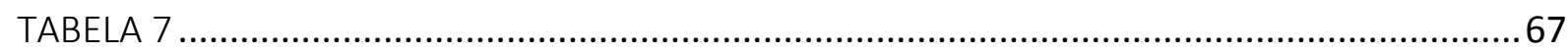

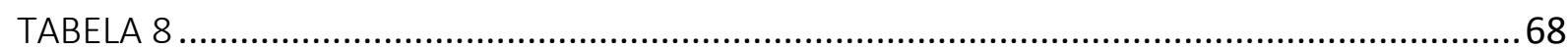

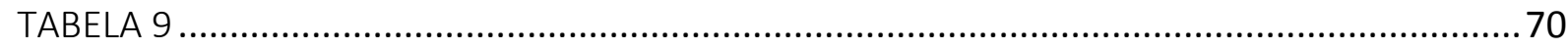

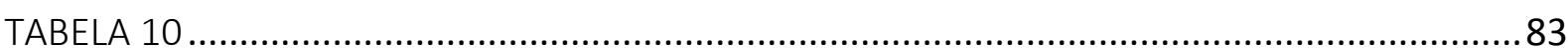

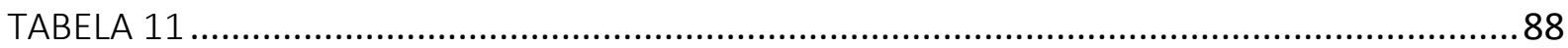

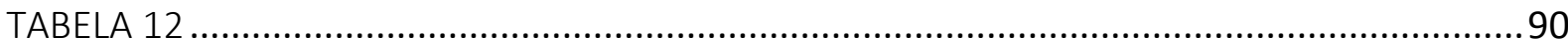

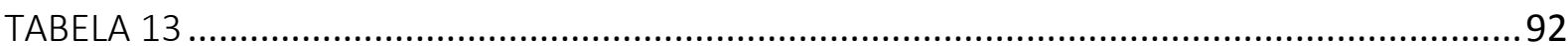




\section{LISTA DE FIGURAS}

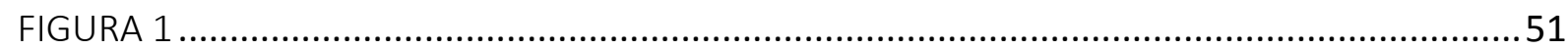

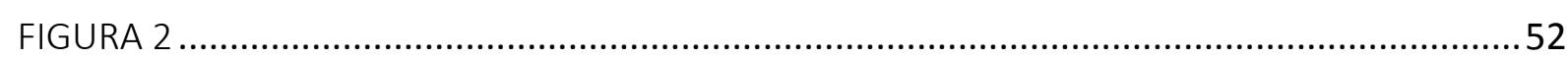

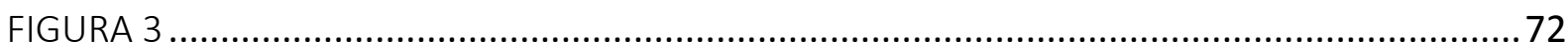

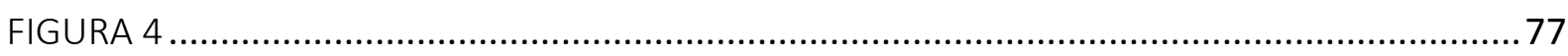

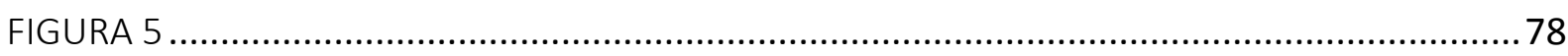

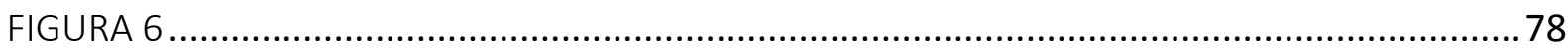

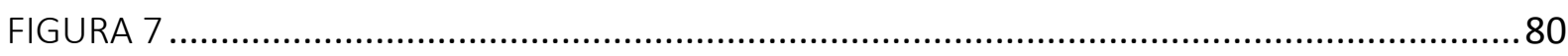

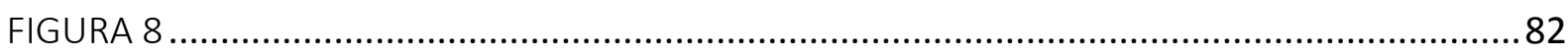

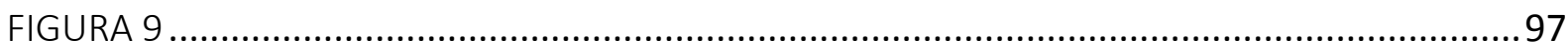

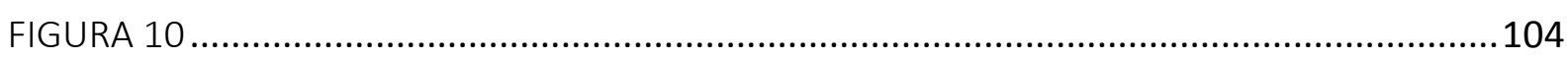

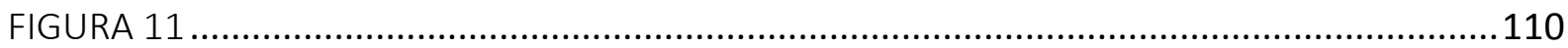




\section{| GLOSSÁRIO DE SIGLAS E ABREVIATURAS}

$\mathrm{Ar}$

$\mathrm{Br}$

CGU

$\mathrm{CNdPC}$

CNPC

FNC

GT

IN

INAI

IPEA

LGBT

MERCOSUL

MinC

MROSC

MSF

NEA

NOA

OEI

ONU

PCV

PNC

SCC

SCDC

SCN

SEGIB

SFC

SInCA

$\mathrm{SNC}$

SPPC

TCC
Argentina

Brasil

Controladoria Geral da União

Comissão Nacional dos Pontos de Cultura

Conselho Nacional de Política Cultural

Fundo Nacional de Cultura

Grupo de Trabalho

Instrução Normativa

Instituto Nacional de Asuntos Indígenas (Argentina)

Instituto de Pesquisa Econômica Aplicada

Lésbicas, Gays, Bissexuais e Travestis, Transexuais e Transgêneros

Mercado Comum do Sul

Ministério da Cultura

Marco Regulatório das Organizações da Sociedade Civil

Modelo "Sintonia Fina"

Nordeste Argentino

Noroeste Argentino

Organização dos Estados Ibero-Americanos para a Educação, a Ciência e a Cultura Organização das Nações Unidas

Programa Cultura Viva

Plano Nacional de Cultura

Secretaria de Cidadania Cultural

Secretaria de Cidadania e Diversidade Cultural

Secretaria de Cultura da Nação Argentina

Secretaria Geral Ibero-Americana

Sistema Federal de Cultura

Sistema de Información Cultural de la Argentina

Sistema Nacional de Cultura

Secretaria de Programas e Projetos Culturais

Termo de Compromisso Cultural 
UNASUL União de Nações Sul-Americanas

UNESCO Organização das Nações Unidas para a Educação, a Ciência e a Cultura 


\section{SUMÁRIO}

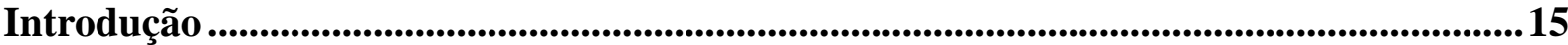

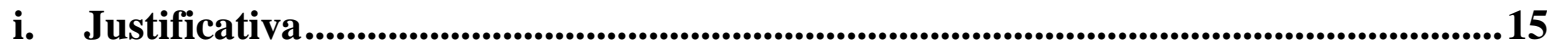

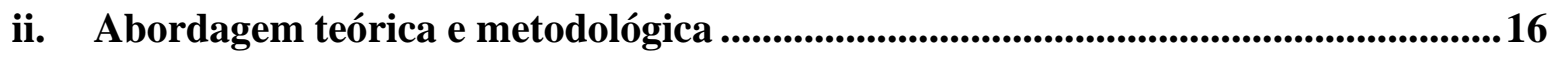

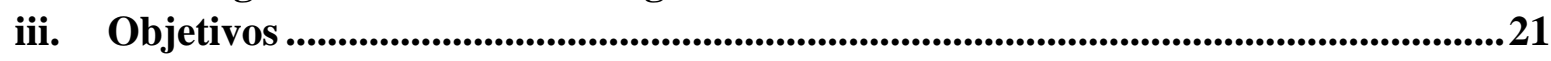

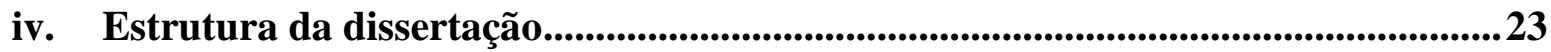

1. Cultura, Desenvolvimento e Cidadania: desafios contemporâneos ...................................24

1.1. DIREITOS CULTURAIS E CIDADANIA: ELEMENTOS FUNDAMENTAIS DA MODERNIDADE

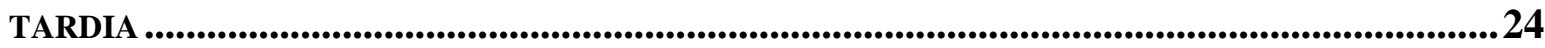

1.2. UM OLHAR TRANSVERSAL SOBRE O DESENVOLVIMENTO_......................................22

1.2.1. A Abordagem das capacidades humanas: desenvolvimento como liberdade ......29

1.2.2 O desenvolvimento na normativa internacional sobre Cultura ................................ 31

1.2.3. Desenvolvimento e pós-desenvolvimento na América do Sul ............................. 37

2. Políticas Culturais de base comunitária: Brasil e Argentina em perspectiva ............ 41

2.1. BRASIL E ARGENTINA: O ESTADO EM AÇÃO NAS POLÍTICAS CULTURAIS....................41

2.2. A Política Nacional de Cultura Viva no Brasil: GÊNESE E TRAJETória de

UM "MODELO"

2.2.1. O programa Cultura Viva: concepção e visão geral ............................................. 43

2.2.2 Evolução do programa: "afinando" e refinando os instrumentos [de gestão] ..........46

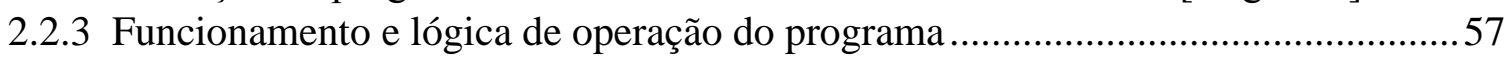

2.2.4 A gestão dos instrumentos: uma teia de desafios e adaptações.................................63

2.3. O Programa Puntos de Cultura na Argentina: AdAPtaÇão ou reinvenÇão? 74

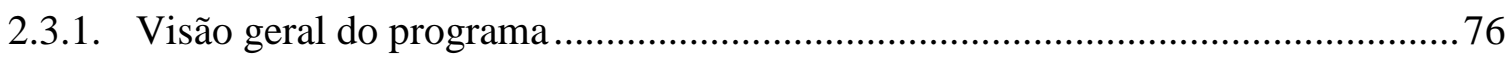

2.3.2. Sobre funcionamento e a lógica de operação do programa: ................................. 83

2.4 QUADRO COMPARATIVO BRASIL-ARGENTINA: UMA ABORDAGEM PRELIMINAR ......92

3. A ação pública cultural: uma análise da implementação dos programas Cultura

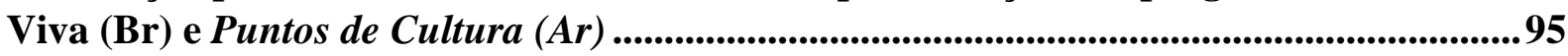

3.1. AS POLÍTICAS PÚBLICAS NA PRÁTICA: ATORES, ARRANJOS INSTITUCIONAIS E

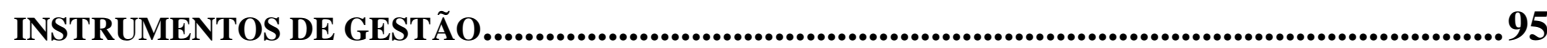

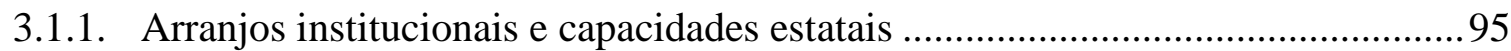

3.1.2. Instrumentos de gestão e a Sociologia da Ação Pública ...................................... 100

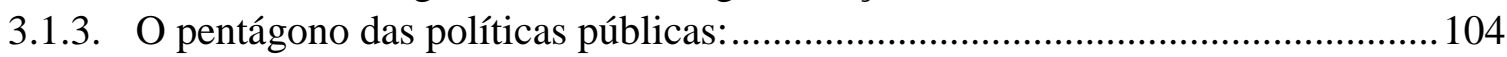

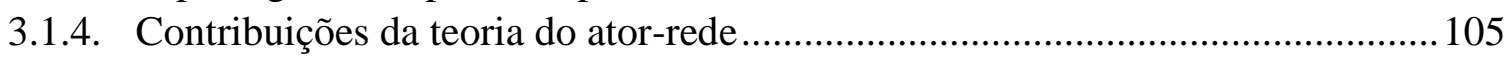

3.2. UMA PROPOSTA DE MODELO DE ANÁLISE DA AÇÃO PÚBLICA CULTURAL ...............107

3.2.1. Aproximações conceituais e complementaridade das abordagens ...................... 107

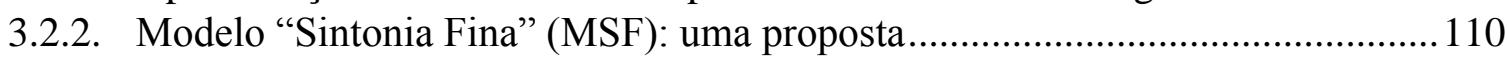

3.3. Análise comparada: Cultura Viva (Br) X Puntos de Cultura (Ar) .........115

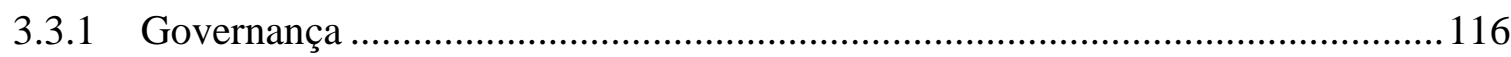

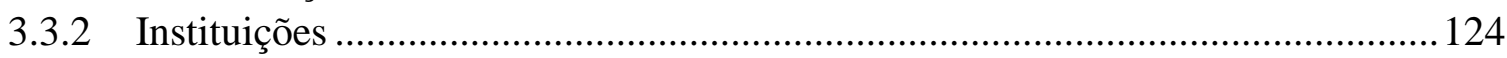

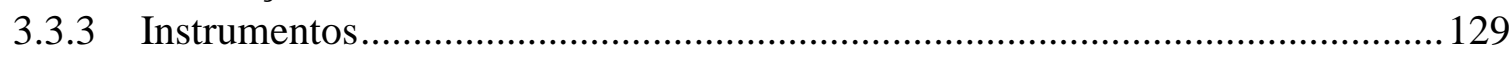

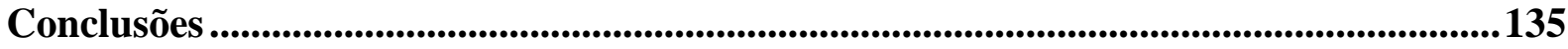

Referências bibliográficas ......................................................................................141 


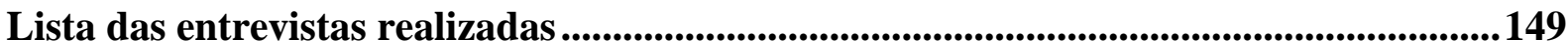

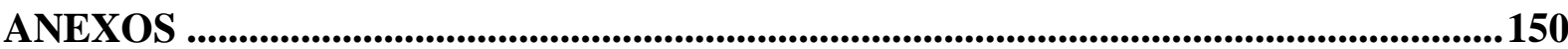

QUESTIONÁRIO PARA ENTREVISTAS COM GESTORES ......................................................151

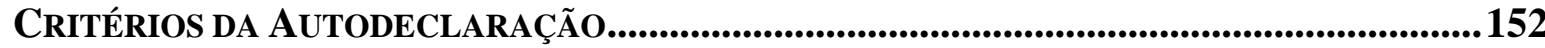




\section{INTRODUÇÃO}

\section{i. Justificativa}

A análise das políticas culturais de base comunitária em países sul-americanos pressupõe o aprofundamento de uma reflexão sobre o cenário das políticas públicas no continente, bem como a maneira pela qual os Estados enfrentam os desafios da promoção do desenvolvimento a partir da implementação de políticas culturais. É importante averiguar como a ação estatal contribui para esse processo e como se dá, na prática, a relação entre o Estado e a sociedade civil. Nesse contexto, torna-se imprescindível observar que características do mundo contemporâneo interferem nessa relação e quais seriam as novas capacidades estatais necessárias para lidar com essa complexidade, considerando os instrumentos de gestão à disposição do Estado.

A análise das trajetórias da Política Nacional de Cultura Viva (Brasil) e do Programa Puntos de Cultura (Argentina), proposta nesta pesquisa, permitirá refletir sobre alguns desses aspectos a partir de um estudo de caso comparado. São dois programas que partem da mesma inspiração e modelo conceitual, porém com estratégias diferenciadas e adaptadas à realidade de cada País. Um olhar mais detido sobre esses casos buscará identificar os elementos comuns e as especificidades locais no tocante à garantia de direitos culturais, cidadania e participação social, bem como na aplicação dos instrumentos presentes na ação pública.

No Brasil, o programa Cultura Viva tem crescentemente despertado a atenção da academia, em especial no campo dos estudos sobre políticas culturais. A variedade de experiências e a diversidade cultural dos Pontos de Cultura proporciona inúmeras reflexões sobre o próprio fazer cultural dos Pontos, numa perspectiva mais antropológica, bem como sobre suas redes de interação com o Estado e com a sociedade em geral, numa abordagem mais sociológica.

Do ponto de vista governamental, o programa Cultura Viva constituiu-se um verdadeiro laboratório de experiências, onde os limites (macro) de atuação do Estado foram e são a todo tempo confrontados com as necessidades singulares de cada Ponto de Cultura. Os estudos e sistematizações encomendados pelo Ministério da Cultura, especialmente ao IPEA e algumas universidades e institutos, concentram-se na avaliação da implementação do programa enquanto política pública, com foco na definição de estratégias para seu redesenho 
e adaptação de seus instrumentos de gestão. Outros estudos acadêmicos enfocam casos específicos de Pontos de Cultura e a contextualização das experiências dos Pontos nos campos simbólico, de garantia e ampliação de direitos, com especial foco no desvendar das ações do próprio programa e seus efeitos sobre outras políticas (juventude, cultura digital, territorialidade, diversidade cultural, políticas afirmativas, culturas indígenas, culturas afrodescendentes, etc.).

Nesse contexto, a despeito da crescente troca de experiências entre governos e redes de atores da sociedade civil na América do Sul sobre políticas culturais de base comunitária, há uma carência de estudos mais aprofundados sobre a relação entre políticas culturais, desenvolvimento e inclusão social na América do Sul. Assim, a partir do estudo comparado entre Brasil e Argentina, esta pesquisa pretende contribuir para essa reflexão, buscando definir parâmetros para melhor compreender os fatores que influenciam a promoção do desenvolvimento na América do Sul.

\section{ii. Abordagem teórica e metodológica}

Esta dissertação é fruto de longo esforço de reflexão e análise sobre as políticas culturais e sua relação com a cidadania e o desenvolvimento. O estudo comparado entre os programas Cultura Viva (Brasil) e Puntos de Cultura (Argentina) revelou as nuâncias de cada proposta e explorou uma via até então pouco explorada nesse tema, ao colocar lado a lado dois programas com características conceituais muito semelhantes, mas com mecanismos de operacionalização e instrumentos de gestão diferenciados.

A construção de um novo olhar sobre políticas públicas que ainda estão em fase de implementação exige um exercício crítico peculiar por parte do pesquisador. Há que se considerar as idealizações da política, os discursos e a prática, os resultados já alcançados e os não alcançados, as mudanças de percurso, as opções estratégicas, as críticas existentes e os desafios que se colocam para o Estado e para os beneficiários da política. Esse não é um exercício trivial. Requer uma análise abrangente do contexto em que se insere a política e, ao mesmo tempo, um olhar detido sobre algumas minúcias e nuâncias da implementação dos programas e projetos. Há que se dar atenção aos níveis macro e micro de análise, enfrentando os riscos inerentes de excessiva generalização ou demasiada especificidade, respectivamente.

Tendo em conta esses riscos e desafios, busquei construir um enfoque diferenciado em relação aos programas e políticas culturais de base comunitária na América do Sul, em 
especial no Brasil e na Argentina, que constituem o foco desta pesquisa. Dado o caráter multidisciplinar do programa de mestrado em Desenvolvimento, Sociedade e Cooperação Internacional, busquei adotar um enfoque metodológico interdisciplinar, utilizando abordagens e métodos de diferentes campos do conhecimento.

De maneira mais abrangente, a pesquisa partiu de uma análise de cunho teórico sobre duas questões essenciais:

i. as relações entre os indivíduos (ou a sociedade civil) e o Estado no contexto das políticas de cidadania cultural, à luz dos debates da teoria social sobre a modernidade tardia (BAUMAN 2010; HARVEY, 1992; SANTOS, 1999 e 2007; MELO; MAKIUCHI, 2014);

ii. a relação entre cultura e desenvolvimento, sob a perspectiva das teorias sobre desenvolvimento e pós-desenvolvimento (SEN, 2010; SANTOS, 2006; PINHEIRO, 2012; RADOMSKY, 2011; ESCOBAR, 2005).

O tema do desenvolvimento e sua relação com as políticas culturais foi observado pela análise de bibliografia e revisão teórica sobre desenvolvimento na América Latina, incluindo a normativa internacional sobre Cultura. Para explicitar a relação intrínseca entre cultura e desenvolvimento, foi necessária uma reflexão conceitual sobre cultura, direitos culturais e desenvolvimento, com vistas a destrinchar as conexões entre esses termos e localizá-las nas estratégias de política cultural que decorrem dessa abordagem, em especial no que se aplica ao Brasil e à Argentina.

Essa reflexão resultou no primeiro capítulo desta dissertação, na forma de um ensaio teórico, por se mostrar a forma mais adequada para tratar as questões propostas, e como salienta MENEGHETTI (2011, p.322):

[...] o ensaio caracteriza-se pela sua natureza reflexiva e interpretativa, diferente da forma classificatória da ciência. No centro do ensaio está a relação quantitativa versus qualitativa. Enquanto a ciência adquire maior autonomia, valorizando aspectos quantitativos para promover generalizações que façam com que um número cada vez maior de pessoas passe a compreender o mundo a partir da instituição de uma racionalidade baseada na calculabilidade, o ensaio valoriza aspectos relacionados às mudanças qualitativas que ocorrem nos objetos ou fenômenos analisados pelos ensaístas.

A segunda parte da pesquisa foi voltada à análise dos programas Cultura Viva (Brasil), e Puntos de Cultura (Argentina), no formato de estudo de caso comparado, com enfoque especial nos instrumentos de gestão das políticas. Foram utilizados referenciais das abordagens de arranjos institucionais e capacidades estatais (GOMIDE; PIRES, 2014; 2014a; 
GOMIDE et al, 2014) dos instrumentos de gestão e da sociologia da Ação Pública (MOISDON, 2006; LASCOUMES; LE GALÈS, 2007; 2012; LÚCIO et al, 2014), além de contribuições da teoria do ator-rede (LAW, 1992; LATOUR, 2012).

Cabe, neste ponto, uma advertência feita por PETERS (2011) sobre a utilidade da triangulação de teorias alternativas e a necessidade de equilíbrio entre teoria e método, sem que um seja refém do outro:

Theory is at once the best friend and the worst enemy of the comparative researcher. [...] Most research published in political science tends to find support for the theory or model being investigated, although in many ways negative findings would be more useful. [...] If we explore the same data with several alternative theories, or go into the field with alternative approaches in mind, we become more open to findings that do not confirm one or another approach. (ibidem, p. 36)

Vale ressaltar que procurei também desenvolver um olhar próprio, autoral, dessas abordagens, observando as diversas representações gráficas dos modelos. A partir desse exercício propus um modelo de análise da ação pública cultural - Modelo "Sintonia Fina" (MSF) - para subsidiar a análise comparada dos dois programas objeto desta pesquisa, com base no tripé governança - instituições - instrumentos. Apostei na consistência e coerência desse modelo - enquanto representação da realidade - a partir dos aspectos presentes nos demais modelos e lógicas de interpretação estudados. Os resultados desse exercício serão apresentados no capítulo 3.

A pesquisa foi conduzida, portanto, a partir da observação e interpretação de dados existentes, utilizando-se do estudo de caso comparado como suporte metodológico para a verificação das hipóteses. Os dados da pesquisa foram recolhidos por meio de análise documental e entrevistas semi-estruturadas e/ou parcialmente estruturadas (LAVILLE \& DIONNE, 1999: p. 188) ${ }^{1}$.

Foram realizadas 6 entrevistas em pesquisa de campo em Buenos Aires (Argentina), sendo 4 gestores do quadro de funcionários do programa Puntos de Cultura, no Ministério da Cultura argentino. Cinco dessas entrevistas foram registradas em áudio, formato .wav e .m4a, totalizando 278 minutos de gravação, das quais duas foram transcritas em língua espanhola.

\footnotetext{
${ }^{1}$ Segundo LAVILLE \& DIONNE (1999: p. 188), a entrevista semi-estruturada contém "série de perguntas abertas, feitas verbalmente em uma ordem prevista, mas na qual o entrevistador pode acrescentar perguntas de esclarecimento". Já a entrevista parcialmente estruturada contém questões abertas previamente preparadas, a partir de temas pré-definidos, "mas com plena liberdade quanto à retirada eventual de algumas perguntas, à ordem em que essas perguntas estão colocadas e ao acréscimo de perguntas improvisadas".
} 
Uma das entrevistas com representantes de um Punto de Cultura não foi registrada em áudio, somente em anotações, devido ao grande número de pessoas presentes no local.

No Brasil, devido ao farto material institucional e de pesquisa disponível sobre o programa Cultura Viva, realizei somente 3 entrevistas com gestores do programa no Ministério da Cultura, abstendo-me de entrevistar membros dos Pontos de Cultura. Duas entrevistas foram registradas em áudio, totalizando 91 minutos de gravação em formato .wav. A terceira entrevista está registrada em anotações. Devido a dificuldades operacionais e de tempo, optei também por não realizar a atividade extra que havia previsto no projeto de pesquisa, qual seja, a enquete com registro fotográfico.

Cabe observar que, em diversos textos e livros são relatados e constatados os logros do programa brasileiro no que se refere à potência de sua narrativa e ao alcance em termos de resgate simbólico da cultura brasileira, seja por meio do registro institucional dos resultados do programa (BRASIL, 2010a, 2010c, 2015; SEMINÁRIO INTERNACIONAL DO PROGRAMA CULTURA VIVA, 2010), seja pela descrição das práticas dos Pontos (IPEA, 2011), seja pela análise acadêmica ou empírica da ação dos pontos e sua intersecção com outras políticas (BARBOSA; CALABRE, 2011).

No entanto, na descrição do capítulo 2, foram enfatizados alguns problemas do programa Cultura Viva e o impacto positivo do programa Puntos de Cultura. Não é fruto do acaso. Foram escolhas conscientes. Mostrar os problemas do programa brasileiro - que nasceu primeiro -, é de alguma maneira lançar um olhar futuro sobre o programa argentino. A sistematização dos problemas e dos caminhos percorridos pelo Cultura Viva para adaptar seus instrumentos pode servir para compor uma espécie de "mapa de bordo" para orientar futuras escolhas.

Obviamente, deve-se levar em conta as diferenças de contexto e da cultura políticoadministrativa entre os dois países, mas o intuito desta pesquisa é buscar elementos comuns de análise sob a perspectiva dos instrumentos de gestão. A trajetória do programa brasileiro mostra uma curva de aprendizagem importante, onde os desafios foram se sobrepondo e exigindo mudanças na gestão do programa.

A base de dados principal para análise do programa brasileiro, do ponto de vista documental, foram livros e artigos acadêmicos, relatórios de pesquisa, relatórios técnicos, documentos institucionais e a "Linha do Tempo da Secretaria da Cidadania e da Diversidade 
Cultural" do Ministério da Cultura - disponível na internet ${ }^{2}$, que reúne a sistematização de Datas e Fatos, Marcos Legais, Eventos e Publicações relacionados ao programa Cultura Viva, durante seus dez primeiros anos de implantação (2004-2014). O site também permite acesso a informações sobre os editais de prêmios e bolsas lançados nesse período, além de documentos e portarias que versam sobre as instâncias de participação do programa.

No caso do programa argentino, as principais fontes de informação documental foram os materiais institucionais do Ministério da Cultura da Argentina, disponíveis na internet ${ }^{3}$, bem como outros documentos obtidos in loco durante a fase de pesquisa de campo.

\footnotetext{
${ }^{2}$ Fonte: http://semanaculturaviva.cultura.gov.br/linhadotempo/. Acesso em 21 jun. 2015.

${ }^{3}$ Fonte: http://puntosdecultura.cultura.gob.ar/docs/puntos. Acesso em 21 jun. 2015.
} 


\section{iii. Objetivos}

\section{Objeto:}

Difusão e implementação de políticas culturais de base comunitária na América do Sul.

\section{Problema de Pesquisa e Hipóteses}

\section{Questão central:}

Com vistas a contribuir para a compreensão de uma pergunta mais abrangente de meu interesse no campo de estudo das políticas públicas, ou seja, uma pergunta de fundo - "Como a política é implementada em contextos diferentes?" - propus a seguinte questão central para esta pesquisa:

- Como ocorre o processo de formulação e implementação de políticas nacionais de cultura e cidadania [de base comunitária] no Brasil e na Argentina, e o que explica a trajetória dessas políticas em cada País?

\section{Questões específicas:}

- O que representa a relação entre cultura e desenvolvimento nos países sul-americanos, e como essa relação tem sido abordada por meio de políticas públicas de cultura e cidadania? Estamos caminhando para o estabelecimento de um "modelo" sulamericano nessa área?

- Como a política pública se desloca para enfrentar os desafios do desenvolvimento e da modernidade contemporânea, no que diz respeito à garantia de direitos culturais, cidadania e participação social? Como isso se reflete na implementação do Programa Cultura Viva (Brasil) e do Programa Puntos de Cultura (Argentina)?

- Quais foram os instrumentos de gestão utilizados nesses programas, e como se relacionaram com os atores envolvidos na política? Qual a influência da utilização de determinados instrumentos de gestão sobre a trajetória e os resultados dessas políticas e programas? 


\section{Hipóteses:}

A) A implementação de políticas públicas de cultura e cidadania [de base comunitária], em países da América do Sul, apresenta especificidades próprias que estão relacionadas à macro visão estatal sobre desenvolvimento, garantia de direitos culturais, promoção da cidadania, participação e emancipação social.

B) O sucesso ou fracasso dessas políticas está intrinsicamente relacionado ao grau de adequação dos seus instrumentos de gestão aos novos desafios da relação entre Estado, sociedade e indivíduos na modernidade contemporânea.

\section{Objetivo-Geral da pesquisa:}

- Analisar a relação entre políticas culturais, desenvolvimento e inclusão social no Brasil e na Argentina, com vistas a identificar e classificar os fatores que influenciam a difusão e/ou replicação de políticas públicas similares em diferentes países sulamericanos.

\section{Objetivos específicos:}

- Identificar e analisar os principais desafios para a promoção de um desenvolvimento social inclusivo na América do Sul, vis à vis as políticas culturais implementadas na região. ${ }^{4}$

- Analisar, em perspectiva comparada, as trajetórias do Programa Cultura Viva (Brasil) e do Programa Puntos de Cultura (Argentina) no que diz respeito à garantia de direitos culturais, cidadania e participação social, situando-as no contexto sul-americano.

- Identificar e analisar os fatores relevantes para adequação dos instrumentos de gestão utilizados nessas políticas/programas aos novos desafios da relação entre Estado, sociedade e indivíduos na modernidade contemporânea.

\footnotetext{
${ }^{4}$ Obs: este objetivo foi considerado muito amplo pela banca de qualificação do mestrado, portanto seu escopo foi reduzido nesta dissertação, a partir do ensaio teórico feito no capítulo 1.
} 
iv. Estrutura da dissertação

A presente dissertação está estruturada em três capítulos, além da introdução e conclusão. A sequência argumentativa e discursiva inicia-se com uma análise dos desafios contemporâneos da relação entre cultura, desenvolvimento e cidadania, a partir os conceitos de direitos culturais, cidadania, participação social, com um olhar transversal sobre desenvolvimento e suas diversas abordagens, especialmente no contexto sul-americano.

O capítulo 2 contém a descrição das trajetórias do Programa Cultura Viva (Brasil) e do Programa Puntos de Cultura (Argentina), apresentando alguns elementos para comparação dos dois programas.

O terceiro capítulo contempla uma primeira seção com uma reflexão sobre as abordagens teórico-metodológicas dos arranjos institucionais e capacidades estatais, instrumentos de gestão e Sociologia da Ação Pública. Na segunda seção é apresentado o Modelo Sintonia Fina (MSF) de Análise da Ação Pública Cultural. Na terceira e última seção é feita uma análise comparada dos programas Cultura Viva (Br) e Puntos de Cultura (Ar), com base nos campos de análise do MSF.

A forma de apresentar o texto é, por vezes, uma conversa com o leitor. O texto foi preparado a partir da premissa de que o leitor não necessariamente conhece os programas estudados, bem como os modelos de análise utilizados. Partiu-se do pressuposto de que dúvidas surgem no meio do caminho, mas podem vir a ser respondidas ou abordadas em uma seção ou capítulo posterior. Sabe-se que ao leitor atento nada passa desapercebido, portanto fica desde já o alerta para que se tente enxergar o texto como uma narrativa que se entrelaça, costurando conceitos, constatações e análises, a partir dos referenciais teóricos e metodológicos aplicados. Além disso, o caráter interdisciplinar do estudo é enfatizado, buscando emprestados conceitos de áreas distintas e aplicando-os ao caso concreto. Tudo feito para o melhor entendimento da realidade, a partir do olhar deste pesquisador.

Sendo assim, encerro esta introdução com o desejo de poder capturar o leitor para o que é essencial, guiado por um raciocínio não-linear, mas consistente, que abraça diversos aspectos das políticas públicas culturais, aplicados aos casos concretos em estudo. 


\title{
1. Cultura, Desenvolvimento e Cidadania: Desafios CONTEMPORÂNEOS
}

\subsection{DIREITOS CULTURAIS E CIDADANIA: ELEMENTOS FUNDAMENTAIS DA MODERNIDADE TARDIA}

No campo da teoria social, esta pesquisa ancora-se, inicialmente, no debate sobre a modernidade tardia e os desafios que se colocam para as relações entre a sociedade civil e o Estado no contexto das políticas culturais. Em tempos de "modernidade líquida" (BAUMAN, 2001), caracterizada pela fluidez e o estado de constante mudança, de liquefação, de derretimento da sociedade, em seus conceitos e práticas cotidianas, a pesquisa busca apontar os desafios de se lidar com a pluralidade de narrativas e novos atores, em contraposição às metanarrativas, sugerindo reflexão mais aprofundada sobre os instrumentos de que o Estado dispõe (ou pode dispor) para lidar com essa complexidade. Realidade complexa onde tempo e espaço não são mais barreiras, onde os deslocamentos e a comunicação são instantâneos, enfim, em que novos desafios se colocam para a subjetividade, a individualidade e o mundo do trabalho (BAUMAN, 2001 apud MELO; MAKIUCHI, 2014).

O conceito de sociedade civil aqui adotado é o seguinte:

\begin{abstract}
A "sociedade civil" deve ser compreendida aqui como o amplo leque de associações voluntárias e movimentos que operam fora do mercado, do Estado e dos laços primários de parentesco e que especificamente se orientam para moldar a esfera pública, incluindo movimentos sociais, sindicatos, grupos de interesse, ONGs autônomas e organizações comunitárias (EVANS e HELLER, 2013 apud HERRLEIN JR., 2014: p. 91)
\end{abstract}

Parte-se da premissa de que as políticas culturais de base comunitária a serem analisadas representam uma superação da dicotomia alta cultura - cultura popular, que segundo Boaventura de Sousa Santos (1999) constitui o "núcleo central do ideário modernista". Essa superação traz consigo o desafio de lidar com novos atores que demandam cada vez mais voz, espaço e protagonismo na complexa teia da participação social. As novas formas de organização e de participação que daí advêm, entretanto, não deixam de refletir as nuâncias da micropolítica das relações de poder e do exercício da resistência [presentes no pensamento de Foucault], considerando a forte relação entre poder e conhecimento e entre poder e discursos [enquanto sistemas de conhecimento adotados em contextos particulares 
para o exercício do controle e do domínio sociais] (HARVEY, 1992 apud MELO; MAKIUCHI, 2014).

"O poder necessita do saber; o saber empresta legitimidade e eficácia (não necessariamente desconectadas) ao poder. Possuir saber é poder" (BAUMAN, 2010, p. 75)

Para LYOTARD apud HARVEY (1992, p. 51), o vínculo social é repleto de jogos de linguagem e o próprio sujeito social está envolvido na disseminação desses jogos, podendo recorrer a distintos códigos a depender do contexto. Nesse sentido, admitindo o conhecimento como principal força de produção, uma questão crucial é como identificar o lugar desse poder "disperso em nuvens de elementos narrativos" e em jogos de linguagem heterogêneos. As instituições seriam, para Lyotard, o local onde se observa uma aparente contradição entre a flexibilidade dos jogos de linguagem e a rigidez do discurso do poder, onde se define o que pode ser dito e como pode ser dito. Segundo LABREA E BARBOSA (2012, p. 2), os Pontos de Cultura, Pontões e gestores do Programa Cultura Viva, no Brasil, construíram uma narrativa sobre o programa, refletindo os lugares sociais e ideológicos de cada sujeito, bem como os interesses sobrepostos, os jogos políticos e a disputa pelo sentido.

Por outro lado, as iniciativas culturais de base comunitária, objeto desta pesquisa, constituem elementos de tensão entre as pressões hegemônicas do global e as contrahegemonias do local (SANTOS, 2006; MELO; MAKIUCHI, 2014). Ou seja, valores e comportamentos sociais e humanos formatados a partir de uma globalização hegemônica, como a homogeneização das identidades, a impermanência de vínculos sociais e humanos e a obsolescência do território/lugar, coexistem, no âmbito local, com a potência da liberdade de ser (diversidade), a necessidade de criar vínculos/redes e a territorialização (MELO; MAKIUCHI, 2014).

Ao focalizar políticas públicas voltadas para esse público, é necessária uma mudança de postura por parte das autoridades públicas, que signifique a passagem do papel de "legislador" - baseado em regras de procedimento e no conhecimento objetivo, ao papel de "intérprete" - que consiste em traduzir afirmações feitas em um contexto para outros, objetivando facilitar a comunicação e impedir distorções de significado (BAUMAN, 2010).

A ideia de interpretação pressupõe que a autoridade reside no autor ou no texto, e o papel do "intérprete" é extrair o significado:

O bom intérprete é aquele que lê o significado da forma adequada - e não há necessidade (ou assim se pode esperar) de alguém para atestar as regras que orientaram a leitura do significado e, deste modo, tornar a interpretação válida ou competente; alguém que peneire as boas interpretações, separando- 
as das ruins. A estratégia de interpretação [...] difere de todas as estratégias de legislação de um modo fundamental: ela abandona abertamente, ou deixa de lado como irrelevante para a tarefa em questão, a hipótese da universalidade da verdade, do juízo e do gosto; ela se recusa a estabelecer diferença entre comunidades que produzam significados; aceita os direitos de propriedade dessas comunidades, e estes como o único fundamento de que os significados comunalmente baseados possam necessitar. (BAUMAN, 2010, p. 266-267)

Há que se lembrar que a base e a sustentação para a implementação de ações voltadas para a garantia de direitos culturais e valorização da diversidade é a noção de que a cidadania cultural e o direito à cultura são pressupostos da pluralidade da criação cultural. O desafio maior é fazer da cultura o elemento central na experiência do sujeito enquanto cidadão, para garantir o acesso equitativo à cultura em todas as suas dimensões - criação, fruição, difusão, produção, consumo, participação e criação de laços de identidade. (IPEA, 2011, p. 51)

De maneira mais ampla e de forma complementar, considerando a evolução dos direitos civis, políticos e sociais elencados por T.H.Marshall (COUTINHO, 1999 e SANTOS, 1999), adotarei o seguinte conceito de cidadania:

Cidadania é a capacidade conquistada por alguns indivíduos, ou (no caso de uma democracia efetiva) por todos os indivíduos, de se apropriarem dos bens socialmente criados, de atualizarem todas as potencialidades de realização humana abertas pela vida social em cada contexto historicamente determinado. (COUTINHO, 1999, p. 42)

Essas são ideias que compõem um pano de fundo teórico para minha pesquisa. Entretanto, a visão de mundo apresentada por teóricos da modernidade tardia, líquida ou reflexiva, nas suas diversas variantes (HARVEY, 1992; BAUMAN, 2001; BAUMAN, 2011; BECK, 2010; BAUDRILLARD, 1991) não é suficiente para compreender os múltiplos aspectos da implementação de políticas culturais na América do Sul. É preciso recorrer também ao debate teórico sobre desenvolvimento, buscando identificar suas relações intrínsecas com a cultura, os direitos culturais e a cidadania. 


\subsection{UM OLHAR TRANSVERSAL SOBRE O DESENVOLVIMENTO}

Pensar a relação entre cultura, cidadania e desenvolvimento pressupõe uma análise do conceito de desenvolvimento a partir de referenciais amplos e de uma perspectiva interdisciplinar. Assim como a cultura, o desenvolvimento também deve ser encarado como um processo de caráter dinâmico e transversal, construído sob o olhar de diferentes disciplinas, de modo a abrigar as dimensões econômica, social, ambiental e cultural. Um conceito a partir desse olhar abrangente ultrapassa a visão do desenvolvimento associado apenas ao crescimento econômico e ao aumento da renda, incorporando todas as dimensões das relações humanas e da sua relação com o ambiente.

Essas relações são carregadas de significados simbólicos que transcendem a dimensão material e incorporam características relacionadas aos modos de pensar e de viver das diferentes comunidades do planeta. É nesse sentido que as políticas culturais em geral e, mais especificamente, os programas que enfatizam a relação entre cultura, cidadania e direitos culturais, podem contribuir para o desenvolvimento das comunidades e dos territórios.

Diante de tudo isso, sinto que ainda há um bom caminho a trilhar até que tenhamos muito claro o papel estratégico que tem a cultura para o desenvolvimento de um País, especialmente quando o queremos de todos.

Enxergamos cultura em toda a trama social. A cultura humana é tudo que resulta da ação humana, de suas interferências sobre o mundo; é tudo que torna visível o pensamento do homem sobre si mesmo e sobre o ambiente que o cerca. Todas as nossas práticas sociais são diferentes formas de concretização da cultura de que fazemos parte. (FERREIRA, 2010)

Nesse contexto, considerando a fluidez que caracteriza a sociedade contemporânea (BAUMAN, 2001) e os efeitos da globalização sobre a economia, as relações de trabalho, os padrões de consumo e de interação entre os indivíduos, o modelo de desenvolvimento adotado em um País necessariamente afeta - de forma direta ou indireta - outros países e regiões do globo. As recorrentes crises financeiras internacionais das últimas décadas trazem à tona a necessidade de uma reflexão mais aprofundada sobre os diferentes modelos de desenvolvimento adotados pelos países num contexto de crescente interdependência.

Superadas as velhas dicotomias da bipolaridade da Guerra Fria e das categorias hierarquizantes de "desenvolvidos" versus "subdesenvolvidos", diferentes países apresentam hoje grandes desigualdades e realidades conflitantes em seus próprios territórios, independentemente do seu status de desenvolvimento. Como enfrentar esses desafios? Que 
aspectos das políticas públicas deveriam ser ressaltados para esse enfrentamento? O que priorizar? E como?

A partir dessas considerações, este capítulo irá explorar o caráter transversal da cultura como elemento essencial do desenvolvimento. A relação entre cultura e desenvolvimento vem sendo abordada de maneira recorrente em diversas instâncias de discussão e decisórias, nos níveis nacional e internacional, bem como incorporada aos mais variados documentos oficiais emanados de cúpulas presidenciais e reuniões internacionais de autoridades culturais, como ONU, Unesco ${ }^{5}, \mathrm{SEGIB}^{6}, \mathrm{OEI}^{7}$, Mercosul e Unasul. Essas declarações refletem uma preocupação de vários governos nacionais com a definição de estratégias sustentáveis para enfrentamento dos desafios do crescimento econômico e do desenvolvimento humano sob uma perspectiva abrangente, responsável e duradoura. Ressaltam, ainda, uma preocupação no sentido inverso, ou seja, com o impacto do desenvolvimento sobre a(s) cultura(s).

Para compreender essa relação biunívoca, entretanto, faz-se necessária uma reflexão conceitual sobre cultura, direitos culturais e desenvolvimento, com vistas a destrinchar as conexões entre esses termos e localizá-las nas estratégias de política cultural que decorrem dessa abordagem, em especial no que se aplica ao Brasil e à Argentina. Utilizarei como ponto de partida o referencial teórico da abordagem das capacidades humanas ou abordagem do desenvolvimento como liberdade, de Amartya Sen (SEN, 2010; PINHEIRO, 2012), e os textos de cinco instrumentos internacionais firmados no âmbito da cultura: a) Declaração Universal sobre a Diversidade Cultural (2001); b) Agenda 21 da Cultura (2004); c) Convenção da Unesco sobre a Proteção e Promoção da Diversidade das Expressões Culturais (2005); d) Carta Cultural Ibero-Americana (2006); e e) Declaração de São Paulo sobre Cultura e Sustentabilidade (2012).

Cabe resgatar, inicialmente, a definição de cultura emanada da Conferência Mundial de Políticas Culturais de 1982:

Permanece atual a síntese que resultou da Conferência Mundial do México ${ }^{8}$ de 1982, ao definir a Cultura como sendo o conjunto de características espirituais e materiais, intelectuais e emocionais que definem um grupo social. [...] englobando modos de vida, os direitos fundamentais da pessoa, sistemas de valores, tradições e crenças, e o Desenvolvimento como um

\footnotetext{
${ }^{5}$ Unesco - Organização das Nações Unidas para a Educação, a Ciência e a Cultura.

${ }^{6}$ SEGIB - Secretaria Geral Ibero-Americana, órgão operativo das decisões emanadas das Cúpulas Ibero-Americanas.

${ }^{7}$ OEI - Organização dos Estados Ibero-Americanos para a Educação, a Ciência e a Cultura.

${ }^{8}$ Conferência Mundial sobre as Políticas Culturais (MONDIACULT, México, 1982).
} 
processo complexo, holístico e multidimensional, que vai além do crescimento econômico e integra todas as energias da comunidade [...] fundado no desejo de cada sociedade de expressar sua profunda identidade. [...] Celso Furtado vai além ao afirmar que, como os projetos de desenvolvimento devem ser definidos pela percepção dos fins e objetivos pretendidos pelos indivíduos e suas comunidades, a dimensão cultural deveria então prevalecer sobre as demais. (MACHADO, 2012: p. 78):

\subsubsection{A Abordagem das capacidades humanas: desenvolvimento como liberdade}

O conceito de desenvolvimento como liberdade, de Amartya Sen, é frequentemente evocado nas análises e abordagens da relação entre cultura e desenvolvimento (MACHADO, 2012; CALABRE, 2012). Para Sen (2010: p. 16), o desenvolvimento é "um processo de expansão das liberdades reais que as pessoas desfrutam”, sendo que o seu alcance está diretamente relacionado à eliminação das principais fontes de privação de liberdade: pobreza e tirania, carência de oportunidades econômicas e destituição social sistemática, negligência dos serviços públicos e intolerância ou interferência de Estados repressivos. As formas de privação incluem, independentemente do nível de riqueza de um País: fomes coletivas, subnutrição, serviços de saúde, educação funcional, saneamento básico, emprego remunerado, serviços públicos inadequados ou falta de acesso aos mesmos, assistência social, violação de liberdades, e negação de liberdades políticas e civis. Pode-se interpretar que, em grande medida, a eliminação das privações está relacionada à questão do acesso (aos serviços públicos, aos mercados, à educação, à infraestrutura, etc.) e à garantia dos direitos fundamentais dos indivíduos, incluindo direitos civis, políticos, sociais e culturais.

Ao afirmar que as liberdades constituem, ao mesmo tempo, os fins primordiais e os meios principais do desenvolvimento, Sen (2010) estabelece uma relação circular de feedbacks múltiplos, na qual maior liberdade gera mais desenvolvimento, e maior nível de desenvolvimento deve gerar mais liberdades, à medida em que as privações de liberdade são enfrentadas. Além disso, o autor defende que as liberdades políticas e econômicas são interrelacionadas, podendo fortalecer umas às outras. Assim, a eliminação da pobreza, por exemplo, pode gerar ascensão econômica de um grupo de indivíduos que, por sua vez, poderão acessar mercados de consumo e facilidades dos quais estavam anteriormente privados; por outro lado, o crescimento econômico pode gerar melhores condições para investimentos em programas sociais e melhoria dos serviços públicos voltados para as camadas mais pobres e, consequentemente, contribuir para a eliminação da pobreza. 
A liberdade assume, portanto, um caráter constitutivo (substantivo) e outro instrumental. As liberdades substantivas dos indivíduos envolvem, por exemplo, a capacidade de evitar a fome e a desnutrição, bem como a possibilidade real de ser alfabetizado e de participar dos processos políticos; desempenham, portanto, um papel constitutivo no conceito de desenvolvimento e avaliativo do processo de desenvolvimento. As liberdades instrumentais, como o próprio termo aponta, servem de instrumentos para que o indivíduo alcance maior grau de liberdade substantiva. (PINHEIRO, 2012)

Os cinco tipos de liberdade instrumental investigados por Amartya Sen (2010: p. 25) são: 1) liberdades políticas; 2) facilidades econômicas, 3) oportunidades sociais, 4) garantias de transparência e 5) segurança protetora. Nesse sentido irei pontuar, mais à frente, como a cultura contribui ou pode contribuir para a conquista dessas liberdades, a partir dos elementos comuns encontradas nos instrumentos internacionais elencados anteriormente.

Por último, vale ressaltar a relação intrínseca que Amartya Sen (2010) estabelece entre liberdade, participação social, democracia e desenvolvimento. Em síntese, por um lado, o exercício das liberdades políticas permite aos indivíduos que participem das decisões públicas, o que fortalece os processos democráticos e, consequentemente, permite melhor adequação das escolhas às necessidades dos indivíduos, escolhas essas baseadas em um conjunto de valores socialmente definidos. Por outro lado, um melhor nível de desenvolvimento permite a focalização das políticas e dos processos democráticos e nas reais necessidades da população, bem como possibilita o desenvolvimento das capacidades dos indivíduos e, consequentemente, impacta positivamente a qualidade da participação social e a eliminação das privações de liberdade. Vale ressaltar aqui que o conceito de capacidade está relacionado ao de oportunidade, ou seja, um indivíduo só é capaz de fazer ou ser algo (ou atingir uma realização) se a ele for dada a oportunidade de fazê-lo ou sê-lo (PINHEIRO, 2012: p. 16) - o que novamente nos remete à questão do acesso em sentido amplo.

Sobre a centralidade da noção de democracia no pensamento de Amartya Sen, vale citar:

Pela via do desenvolvimento com liberdade, o autor [Amartya Sen] incorpora, com profundidade ímpar no pensamento social contemporâneo, as diferentes perspectivas e modos de vida existentes nas sociedades na composição da multifacetada equação do desenvolvimento (ou, da perspectiva dos agentes, dos seus próprios desenvolvimentos), atribuindo, deste modo, uma centralidade inescapável à dimensão política, ou em termos mais precisos, à necessidade inescapável da democracia, tanto como meio [como a única plataforma social capaz de reverberar e equacionar em 
consensos - ainda que contingentes - as diversas vontades e anseios] e como finalidade do desenvolvimento - ou seja, enquanto um telos qualificante que ao tempo em que se realiza, contribui para aperfeiçoar os objetivos e os rumos do desenvolvimento. (ACCO, 2009: p. 214)

À luz dessa abordagem, partimos para a análise de alguns instrumentos internacionais que conclamam a cultura como elemento constitutivo do desenvolvimento e apontam os principais condicionantes para o pleno exercício dos direitos culturais.

\subsubsection{O desenvolvimento na normativa internacional sobre Cultura}

\section{Declaração Universal sobre a Diversidade Cultural (2001)}

A Declaração Universal sobre a Diversidade Cultural recupera os princípios da Declaração Universal de Direitos Humanos e reafirma que o exercício dos direitos culturais são condição para o pleno exercício dos direitos humanos e liberdades fundamentais, situando-os no contexto do processo de globalização. Trata-se de instrumento balizador dos direitos culturais e que lança as bases para a futura adoção de Convenção específica sobre a diversidade cultural no âmbito da Unesco. No que tange ao desenvolvimento, a declaração preconiza no seu artigo 3 que:

A diversidade cultural amplia as possibilidades de escolha que se oferecem a todos; é uma das fontes do desenvolvimento, entendido não somente em termos de crescimento econômico, mas também como meio de acesso a uma existência intelectual, afetiva, moral e espiritual satisfatória.

\section{Agenda 21 da Cultura (2004)}

A Agenda 21 da Cultura ${ }^{9}$ é um documento firmado por representantes de governos locais de diversas partes do mundo, preconizando "um compromisso das cidades e dos governos locais para o desenvolvimento cultural”. Reafirma os princípios da Declaração

\footnotetext{
${ }^{9}$ Agenda 21 da Cultura - Foi firmada em 8 maio de 2004, em Barcelona, no IV Fórum de Autoridades Locais de Porto Alegre para a Inclusão Social, no marco do Fórum Universal das Culturas, como "documento orientador das políticas públicas de cultura e como contribuição para o desenvolvimento cultural da humanidade".
} 
Universal sobre a Diversidade Cultural (2001), caracterizando a diversidade como principal patrimônio da humanidade e afirmando que a liberdade cultural dos indivíduos é condição essencial da democracia. Propõe compromissos e recomendações relacionados com a implementação de políticas culturais e adoção de medidas voltadas para a valorização da cultura na sua relação com o território e com os espaços urbanos. Destaca-se a seguinte menção específica ao desenvolvimento:

A afirmação das culturas, assim como o conjunto das políticas que foram postas em prática para o seu reconhecimento e viabilidade, constitui um fator essencial no desenvolvimento sustentável das cidades e territórios no plano humano, econômico, político e social. O carácter central das políticas públicas de cultura é uma exigência das sociedades no mundo contemporâneo. A qualidade do desenvolvimento local requer $o$ imbricamento entre as políticas culturais e as outras políticas públicas sociais, econômicas, educativas, ambientais e urbanísticas.

\section{Convenção da Unesco sobre a Proteção e Promoção da Diversidade das Expressões} Culturais (2005)

A Convenção da Unesco de 2005, comumente chamada de "Convenção da Diversidade", versa sobre os direitos e as obrigações dos seus Estados-Parte no que se refere à formulação e implementação de políticas culturais e à adoção de medidas para a proteção e a promoção da diversidade das expressões culturais, entendidas como "aquelas expressões que resultam da criatividade de indivíduos, grupos e sociedades e que possuem conteúdo cultural" (art. 4). Constitui um marco legal inovador do direito internacional, na medida que reconhece que "os bens e serviços culturais comunicam identidades, valores e significados e, por isso, não podem ser considerados meras mercadorias ou bens de consumo quaisquer", ou seja, "a cultura encontrou um lugar de destaque na agenda política a partir da preocupação com a necessidade de se humanizar a globalização" (UNESCO, sem data: p. 22-24)

Dentre seus objetivos, destacam-se três que se relacionam de maneira especial com abordagem das capacidades humanas de Amartya Sen:

Artigo 1 - Os objetivos da presente Convenção são:

[...] (b) criar condições para que as culturas floresçam e interajam livremente em benefício mútuo; [...]

(f) reafirmar a importância do vínculo entre cultura e desenvolvimento para todos os países, especialmente para países em desenvolvimento, e encorajar as ações empreendidas no plano nacional e internacional para que se reconheça o autêntico valor desse vínculo; 
(g) reconhecer a natureza específica das atividades, bens e serviços culturais enquanto portadores de identidades, valores e significados.

As medidas preconizadas pela Convenção incluem, entre outras: medidas regulatórias; criação de oportunidades às atividades, bens e serviços culturais (para sua criação, produção, difusão, distribuição e fruição); acesso efetivo aos meios de produção, difusão e distribuição, para as indústrias culturais e os setores informais; estímulo à criatividade, ao espírito empreendedor e à circulação. Ao estabelecer tanto medidas para a promoção quanto para a proteção das expressões culturais, a Convenção reconhece o valor da cultura enquanto promotor do desenvolvimento, ao mesmo tempo em que busca proteger as expressões culturais tradicionais (ou aquelas em risco de extinção) dos efeitos negativos do desenvolvimento desenfreado e de modelos de desenvolvimento predatórios.

A convenção dedica dois artigos específicos para explicitar a relação entre cultura e desenvolvimento: art. 13 - Integração da Cultura no Desenvolvimento Sustentável; e art. 14 - Cooperação para o Desenvolvimento. Nesses artigos, enfatiza a necessidade de integração da cultura nas políticas de desenvolvimento dos países e estimula a cooperação para o desenvolvimento sustentável e a redução da pobreza, com vistas a favorecer a emergência de um setor cultural dinâmico. $\mathrm{O}$ enfoque da cooperação tem uma vertente econômica de fortalecimento das indústrias culturais, especificamente em países em desenvolvimento, e outra de fortalecimento das capacidades estratégicas para formulação e implementação de políticas, com ênfase na transferência de tecnologias e conhecimentos.

Por último, a Convenção pressupõe e incentiva a participação ativa da sociedade civil na proteção e na promoção da diversidade das expressões culturais, inclusive nos esforços empreendidos pelos Estados-Partes.

\section{Carta Cultural Ibero-Americana (2006)}

A Carta Cultural Ibero-Americana recupera os princípios e instrumentos preconizados na Declaração sobre a Diversidade Cultural (2001) e na Convenção da Diversidade (2005), reconhecendo e valorizando os programas de desenvolvimento cultural e reafirmando os valores da democracia, a livre criação, a plena participação dos povos na cultura, bem como a necessidade de que isso ocorra num ambiente de liberdade e justiça. Afirma também que "o exercício e a fruição das manifestações e expressões culturais devem ser entendidos como 
direitos de caráter fundamental. A Carta considera que o exercício da cultura é uma dimensão da cidadania que contribui para a coesão e a inclusão social, gerando confiança e auto-estima.

O documento ainda destaca o valor estratégico da cultura na economia e sua contribuição para o desenvolvimento econômico, social e sustentável do espaço iberoamericano, mas aponta em primeiro lugar a necessidade de afirmação do valor central da cultura como base para o desenvolvimento integral do ser humano e a superação da pobreza e da desigualdade.

Dentre seus princípios, destacam-se os seguintes: Princípio de reconhecimento e de proteção dos direitos culturais, entendidos como direitos de caráter fundamental vinculados ao caráter integral dos direitos humanos, cujo exercício deve permitir a realização de suas capacidades criativas, o acesso, a participação e a fruição da cultura - tais direitos são a base da cidadania plena e tornam os indivíduos os protagonistas no campo cultural; Princípio de complementaridade, que ressalta a relação complementar entre o econômico, o social e o cultural; Princípio de contribuição para o desenvolvimento sustentável, a coesão e a inclusão social.

Como âmbitos de aplicação, a Carta Cultural elenca as seguintes relações com o campo da cultura: cultura e direitos humanos; culturas tradicionais, indígenas, de afrodescendentes e de populações migrantes; criação artística e literária; indústrias culturais e criativas; direitos de autor; patrimônio cultural; educação; ambiente; ciência e tecnologia; comunicação; economia solidária; e turismo. Este amplo espectro realça o caráter transversal da cultura e suas inúmeras possibilidades de contribuir para a redução ou eliminação de diversas privações de liberdade. $\mathrm{O}$ estímulo à criatividade, a garantia do direito à educação básica, o fomento ao livro e à leitura, a valorização das culturas tradicionais, o acesso aos bens e serviços culturais e aos meios de produção cultural, são todos exemplos de eliminação das privações e expansão das liberdades, refletindo os condicionantes do desenvolvimento preconizados por Amartya Sen.

\section{Declaração de São Paulo sobre Cultura e Sustentabilidade ${ }^{10}$ (2012).}

\footnotetext{
${ }^{10}$ A Declaração de São Paulo sobre Cultura e Sustentabilidade foi assinada em 14 de abril de 2012, no âmbito da Reunião de Altas Autoridades Sul-Americanas sobre Cultura e Sustentabilidade, pelos Ministros, Secretários de Estado e demais autoridades da Cultura dos seguintes países: Argentina, Bolívia, Brasil, Chile, Equador, Paraguai, Peru e Uruguai. O documento foi posteriormente reconhecido pela Reunião de Ministros do Mercosul e pelos Presidentes dos Estados Partes e
} 
A Declaração de São Paulo sobre Cultura e Sustentabilidade (2012) foi assinada no âmbito das atividades preparatórias para a Conferência Rio+20, em um contexto de forte crise financeira internacional. Ancorada nos princípios elencados por todos os instrumentos analisados acima, a Declaração enfatiza no seu preâmbulo a "transversalidade e o papel da cultura na construção de uma resposta aos desafios da sustentabilidade e do desenvolvimento humano com equidade e inclusão social", reconhecendo a diversidade cultural como condição para o desenvolvimento sustentável "em benefício das gerações atuais e futuras".

A novidade na Declaração é que incorpora ao seu texto algumas características próprias dos países sul-americanos, como a promoção do conceito do "Bem Viver":

Promover o conceito do "Bem Viver" (Sumak Kawsay, na língua quéchua; Sumaq Qamaña, na língua aymará; e Tekó Porã, na língua guarani; entre outras) como perspectiva enriquecedora da sustentabilidade. Esta nova forma de ética cidadã, concebida a partir da articulação organizada, sustentável e dinâmica dos sistemas econômico, político, social, cultural e ambiental, tem como objetivo garantir a reprodução da vida com um horizonte intergeracional. (Art. 2)

Passa-se a reconhecer também o componente ambiental da diversidade cultural dos povos sul-americanos. A herança cultural dos povos originários abrange conhecimentos tradicionais e modos de viver próprios e maneiras peculiares de interagir com o ecossistema e com seu patrimônio material e imaterial. Dessa forma, amplia-se o conceito de desenvolvimento e defende-se a cultura como quarto pilar do desenvolvimento, "reconhecendo-a como dimensão articuladora e geradora de equilíbrio entre os três pilares até o momento reconhecidos: o econômico, o social e o ambiental.

\section{Em resumo:}

A perspectiva cultural do desenvolvimento nos obriga a adotar um olhar transversal sobre o tema, agregando as dimensões econômica, social, ambiental e cultural do desenvolvimento. A partir da abordagem das capacidades humanas, de Amartya Sen (2010), foi possível identificar nos instrumentos internacionais vigentes na área da cultura alguns elementos essenciais para o desenvolvimento das liberdades substantivas e instrumentais, que constituem o fim e os meios do desenvolvimento. No que tange às cinco categorias de

Associados do bloco. No âmbito da Unesco, o conteúdo da Declaração foi acolhido como subsídio para o processo de discussão e formulação dos Objetivos do Desenvolvimento Sustentável (ODS) e da Agenda de Desenvolvimento Pós-2015 da ONU. 
liberdades instrumentais elencadas por Amartya Sen, pode-se concluir que existem os seguintes traços comuns:

1) liberdades políticas - os vários instrumentos enfatizam a plena realização dos direitos humanos e direitos culturais, bem como a proteção e a promoção da diversidade das expressões culturais, como condição para o pleno exercício da cidadania, a participação social e liberdade criativa, num ambiente democrático;

2) facilidades econômicas - o reconhecimento da dimensão econômica da cultura pressupõe o acesso aos meios de produção, difusão e distribuição de bens e serviços culturais como pré-condição para o pleno exercício da criação e da fruição. Adicionalmente, a cultura apresenta-se como importante ferramenta de geração de renda e que, portanto, movimenta a economia. O financiamento da cultura torna-se, portanto, elemento fundamental nesse processo. Tornam-se igualmente necessárias medidas de proteção da diversidade das expressões culturais, considerando, por exemplo, os efeitos negativos da globalização ou privações de liberdades aos povos e comunidades tradicionais, advindas de modelos de desenvolvimento predatório das capacidades individuais;

3) oportunidades sociais - a cultura pode contribuir para a redução das desigualdades, o combate à violência e a redução da pobreza, constituindo-se portanto em fator com alto potencial de desenvolvimento de liberdades e eliminação de privações. Enfatiza-se o caráter transversal da cultura e sua relação com a educação, o turismo, o meio ambiente e a economia solidária, entre outras áreas. Elucida-se, ainda, a relação entre o desenvolvimento cultural e o desenvolvimento urbano, considerando as múltiplas interfaces entre os indivíduos e o ambiente das cidades, como a proteção do patrimônio, o acesso à infraestrutura cultural e aos meios de produção, distribuição e fruição locais.

4) garantias de transparência - essas garantias estão fundamentalmente ligadas ao compromisso dos direitos culturais com a liberdade de expressão, de pensamento e de criação. A criatividade só é possível de ser exercida em um ambiente de plena transparência, onde tais direitos fundamentais são assegurados;

5) segurança protetora - para proporcionar uma rede de segurança social, os instrumentos internacionais analisados defendem uma atuação decisiva do Estado enquanto formulador e implementador de políticas culturais inclusivas, garantindo o respeito às minorias de exercerem seus direitos culturais, bem como a proteção dos conhecimentos tradicionais como forma de garantir a manutenção do bem estar para gerações presentes e 
futuras.

Esses são apenas alguns dos elementos essenciais que estão presentes nos documentos analisados, mas que demonstram uma relação complementar entre os instrumentos, nos quais o desenvolvimento aparece como elemento comum que vai adquirindo novas características no decorrer do tempo e de acordo com o contexto histórico, político e econômico de sua época. Analisar esse processo era o propósito desta reflexão.

\subsubsection{Desenvolvimento e pós-desenvolvimento na América do Sul}

É preciso atentar, entretanto, que em suas distintas elaborações teóricas, o discurso do desenvolvimento evoca traços que são próprios do pensamento da cultura ocidental. Mas há autores - como José de Souza Silva e Arturo Escobar - que, convencidos da percepção etnocêntrica de Ocidente relacionada à ideia de desenvolvimento, propõem uma desconstrução da ideia de desenvolvimento, para uma "descolonização" do pensamento eurocêntrico hegemônico (DE SOUZA SILVA apud MARTÍNEZ e DE ANGELIS, 2013).

Rompendo com velhos paradigmas, a ânsia do desenvolvimento desenha agora caminhos plurais e heterogêneos com diferentes matizes. No Brasil, é quase lugar comum entre especialistas a obra de Amartya Sen, que quase adquire um véu aurático e de ponto de mutação sobre o tema renovando a esperança redentora do desenvolvimento - agora "como liberdade". Além deste, são especialmente incorporados ao debate a perspectiva sobre capital social, a crítica do desenvolvimento igualado a crescimento (propagado pela noção de desenvolvimento sustentável) e os novos olhares sobre as instituições como centrais para a mudança social. [...] Menos discutidos pela ciência social brasileira, entretanto, são os pontos de vista elaborados pela antropologia do desenvolvimento e pelas perspectivas pós-estruturalista e pós-colonial sobre o assunto, quando nos anos de 1990, o diálogo crítico permitiu o aparecimento da perspectiva denominada de pósdesenvolvimento. (RADOMSKY, 2011: p. 150)

Como advertem Martínez e Angelis (2013), um modelo de desenvolvimento baseado nas especificidades culturais poderia provocar uma revisão epistemológica e um olhar de ruptura conceitual do enfoque de direitos e, em última instância, relativizar e questionar o saber institucionalizado e a percepção do desenvolvimento como meta última de toda a sociedade e a presunção de universalidade dos valores que estão presentes no modelo ocidental de desenvolvimento. 
No entanto, com todas as vicissitudes e os desgastes, a ideia de desenvolvimento (e todos os derivados que geralmente aparecem ligados ao termo "desenvolvido": sub, semi, pós) não perde força imaginativa e poder conceitual, mesmo em meio à ruína que um olhar crítico poderia depurar. Artifício ideológico, implicação de um poder discursivo ou esperança de superação de problemas como a pobreza e a desigualdade, deve-se destacar sua resiliência diante das tentativas de desconstrução. (RADOMSKY, 2011: p. 149)

Segundo RADOMSKY (2011), o pós-desenvolvimento não é um programa unitário e homogêneo de pensamento, mas o que aproxima seus autores é a crítica do modelo de desenvolvimento planejado a partir de meados do século XX. Citando Gilbert Rist e Arturo Escobar como principais representantes desse movimento intelectual, Radomsky (2011) chama a atenção para as diferenças do pensamento dos dois autores. Segundo ele, o pensamento de Rist vai na direção a uma crítica histórica focada na ruína do desenvolvimento a partir das expressões de seus próprios porta-vozes. Nesse sentido, o ponto de partida conceitual no entendimento de Rist seria o seguinte:

"Desenvolvimento" consiste de um conjunto de práticas, às vezes aparecendo em conflito uma com outra, que requer - para a reprodução da sociedade - a transformação geral e a destruição do ambiente natural e das relações sociais. Seu objetivo é aumentar a produção de mercadorias (bens e serviços) direcionadas, pelo mecanismo da troca, para demanda efetiva. (RIST, 2008 apud RADOMSKY, 2011: p. 154)

Radomsky (2011) complementa que, para Escobar, a reflexão sobre o desenvolvimento estaria mais alinhada à crítica da modernidade, ou mais especificamente a busca por alternativas à modernidade. Por outro lado, os críticos do pós-desenvolvimento chamam a atenção para o risco de romantização e confiança excessiva que os intelectuais teriam depositado em movimentos sociais - compreendidos como "espaços em que relações efetivamente democráticas e antiautoritárias imperam" -, culpando Estados, organismos e agências de desenvolvimento e vinculando sua esperança na capacidade da sociedade civil e dos movimentos sociais de agirem como "libertadores da máquina autoritária" (STOREY, 2000 apud RADOMSKY, 2011: p. 155).

Uma outra corrente, com repercussão crescente na América do Sul, especialmente o Equador, refere-se à noção de buén vivir (bem-viver, em português, ou sumak kawsay em quéchua) como a representação do que o desenvolvimento deve(ria) ser (WALSH, 2010; ESCOBAR, 2010 apud RADOMSKY, 2011: p. 158). 
$\mathrm{Na}$ realidade, Walsh mostra que viver bem é antes de tudo um projeto coletivo, daí o direcionamento que transmuta [quando apropriado politicamente] os atuais esforços das organizações e agências internacionais em torno do desenvolvimento humano, ou das formas ainda insistentes na dimensão material do desenvolvimento pensado como expansão tecnológica, de capital e de infraestruturas. Coletivo por princípio, interroga igualmente os aparelhos que querem criar liberdades econômicas, capacidades, oportunidade individuais e acesso a mercados como é o enaltecido projeto (liberal?) de Amartya Sen (2000). (RADOMSKY, 2011: p. 158)

Já Boaventura de Souza SANTOS (2006) propõe que isso seja pensado em termos de superação da modernidade ocidental a partir de uma análise da globalização como uma zona de confrontação entre projetos hegemônicos e contra-hegemônicos, onde o "Sul" emerge como protagonista de uma globalização contra-hegemônica. Como a globalização transporta valores culturais, torna-se importante discutir como produzir formas alternativas de ser, novas relações sociais e novas possibilidades de resistência. Em última instância, a preocupação é como fazer emergir as vozes subalternas na valorização de tradições locais e na inversão das relações de poder.

Propongo [...] como orientación epistemológica política y cultural, que nos desfamiliaricemos del Norte imperial y que aprendamos con el Sur. Mas advierto que el Sur es en sí, un procduto del imperio y por eso aprender con el Sur requiere igualmente una desfamiliarización en relación al Sur imperial, es decir en relación a todo lo que en el Sur es resultado de la relación capitalista colonial. Así solo se aprende del Sur en la medida que éste se concibe como resistencia a la dominación del Norte y que se busca en él lo que no ha sido totalmente desfigurado o destruído por tal dominación. En otras palabras, solo se aprende del Sur en la medida que se contribuya a su eliminación como producto del imperio. (SANTOS, 2006: p. 44 apud MELO; MAKIUCHI, 2014: p. 73)

Para HERRLEIN JR. (2014), entretanto, há relação entre o conceito de "desenvolvimento como liberdade", de Amartya Sen, e o conceito de "desenvolvimento endógeno", cunhado por Celso Furtado (1984 apud HERRLEIN JR., 2014). O caráter endógeno do processo de desenvolvimento corresponde à faculdade das comunidades humanas de "ordenar o processo acumulativo em função de prioridades por ela mesma definidas" (HERRLEIN JR., 2014, p. 88).

Existe uma correspondência entre o "desenvolvimento como liberdade" e o "desenvolvimento endógeno", embora o primeiro conceito coloque a ênfase no indivíduo social e moral, enquanto o segundo, na coletividade histórica. Ambos os conceitos (pres)supõem deliberação. Enquanto Furtado (1984) enfatiza a criatividade e a invenção no desenvolvimento, atributos que se 
fundamentam nas capacidades culturais dos indivíduos que compõem o povo ou as elites, Sen (2000) enfatiza a liberdade individual e a construção democrática da medida social do desenvolvimento, o que recai na noção de endogeneidade. (HERRLEIN JR., 2014: p. 88)

Como se pode perceber, o conceito de desenvolvimento tem sido objeto de larga discussão e reflexão acadêmica, a partir de visões críticas que apontam para a definição de alternativas aos modelos de desenvolvimento tradicionalmente preconizados pelas agências internacionais e absorvidos pelos governos de diversos países. Não obstante, é importante observar as diferentes nuâncias desse conceito e sua possível interface com a cultura e as políticas culturais. Portanto, esta pesquisa não adotou um conceito único de desenvolvimento, mas apenas se valeu das diferentes visões com vistas a situar as políticas culturais do Brasil e da Argentina nesse contexto, sempre que possível localizando e resgatando outros conceitos presentes, como cidadania, direitos culturais, democracia, liberdade e participação.

Desta forma, o intuito aqui não é esgotar a discussão sobre desenvolvimento, mas apenas contextualizar as políticas culturais voltadas para a garantia dos direitos culturais e da cidadania, de forma a subsidiar o estudo comparado dos programas Cultura Viva ( $\mathrm{Br})$ e Puntos de Cultura (Ar) a partir do próximo capítulo.

Essa reflexão será feita considerando as três dimensões da cultura presentes no conceito adotado pelo governo brasileiro a partir de 2003, conforme destacado nas palavras do Ministro da Cultura, Juca FERREIRA:

Diante desta compreensão passamos a operar uma política cultural unindo três de suas dimensões mais fundamentais.

Inicialmente, a cultura em sua dimensão simbólica. A arte e a cultura intimamente conectadas com a interpretação que fazemos do mundo. Afinal, é no campo da cultura que se qualifica as relações sociais. É ela quem "dá liga”à cidadania. É através dela que nos identificamos como partes de uma mesma nação. [...]

Depois, a dimensão cidadã. A cultura como fator de inserção social, com um direito fundamental, como uma necessidade humana básica, essencial, tão importante quanto a alimentação, a moradia, a educação e a saúde. Algo sem o que o ser humano não se realiza.

E, por fim, a cultura como matéria prima de um dos processos mais dinâmicos da economia, sua dimensão econômica, algo em franca expansão em todo o planeta e já, hoje em dia, responsável por uma parcela considerável de nosso PIB, superando em muito vários setores tradicionalmente dinâmicos do mundo dos negócios. (FERREIRA, 2010) 


\section{Políticas Culturais de base comunitária: Brasil E} ARgENTINA EM PERSPECTIVA

\subsection{BRASIL E ARGENTINA: O ESTADO EM AÇÃO NAS POLÍTICAS CULTURAIS}

As propostas de estudo sistematizado das políticas públicas de cultura na América do Sul são recentes. No Brasil, as políticas culturais começaram a se desenvolver a partir da década de 1930, tendo como objeto formas culturais específicas, consideradas como boas formas de expressão humana tratadas como universalizáveis, ou valorizadas na sua singularidade, enquanto expressão de certas comunidades e indivíduos. Podem ser consideradas uma sinergia de ideias, valores, normas, instrumentos de ação, operações, atores sociais, dispositivos institucionais, orçamentos, instituições, etc. Mas a política é, sobretudo, uma construção, um processo. (IPEA, 2011: pp. 26-27).

A partir dos anos 2000, a economia mundial apresenta novas complexidades, pressionada pela alta tecnologia, pelo deslocamento da noção de valor e pela busca de maior acesso ao conhecimento e à capacitação - motivos que impulsionam os governos a encarar a cultura e os cidadãos como o que o ex-Ministro da Cultura Gilberto Gil chamava de "ponto de partida e de chegada do crescimento e da distribuição de riqueza” (BRASIL, 2006: prefácio).

Concomitantemente, observa-se na América do Sul a ascensão de governos com forte influência ideológica de esquerda que, no campo da cultura, passaram a promover um gradual reforço do papel do Estado na formulação e implementação de políticas públicas de cultura. $\mathrm{O}$ discurso interno e as discussões nos fóruns de debate regionais ${ }^{11}$ incorporaram também a noção de que a sociedade civil e os setores culturais devem ser protagonistas, pois são eles que produzem a diversidade de expressões culturais e os conhecimentos e formas de viver que constituem a dinâmica cultural.

Os direitos culturais devem ser entendidos como direitos de caráter fundamental, segundo os princípios de universalidade, indivisibilidade e interdependência. Seu exercício desenvolve-se no âmbito do caráter integral dos direitos humanos, de forma tal que esse mesmo exercício permite e facilita, a todos os indivíduos e grupos, a realização de suas capacidades criativas, assim como o acesso, a participação e a fruição da cultura. Estes direitos são a base da plena cidadania e tornam os indivíduos, no conjunto

\footnotetext{
${ }^{11}$ Dentre os principais fóruns regionais nesse âmbito, destacam-se: a Reunião de Ministros da Cultura do Mercosul (RMC), realizada semestralmente na programação oficial das presidências Pro Tempore do Mercosul: e a Conferência Ibero-Americana de Ministros da Cultura, realizada anualmente pela Organização dos Estados Ibero-Americanos para a Educação, Ciência e Cultura (OEI), em seguimento às Cúpulas Ibero-Americanas de Chefes de Estado e de Governo.
} 
social, os protagonistas dos afazeres no campo da cultura. (Carta Cultural Ibero-Americana, 2006: Princípios)

No Brasil, a partir de 2003, surge uma gama de políticas e programas culturais que privilegiam o acesso à cultura e aos meios de produção cultural como um dos elementos norteadores da política nacional de cultura. Além disso, o Ministério da Cultura (MinC) passa a defender que o Estado tem grande papel de promover meios e equipamentos para universalizar a todos os brasileiros o acesso a uma cidadania plena, sendo ao mesmo tempo gestor da política cultural do País e ator garantidor de direitos culturais. Um dos programas mais emblemáticos desse esforço é o Programa Nacional de Cultura, Educação e Cidadania (Programa Cultura Viva), que congrega a rede nacional de Pontos de Cultura. Criado em 2004, o programa consolida-se como Política Nacional de Cultura Viva, instituída pela Lei n $^{\circ}$ 13.018 de julho de 2014 - a "Lei Cultura Viva”. (BRASIL 2005; 2006; 2010a; 2010b; 2015 ).

Na Argentina, também a partir de 2003, a política cultural passa a fazer parte de um projeto político nacional "amplo, democrático e inclusivo" de recuperação dos diretos sociais e culturais, onde as organizações sociais de base popular e comunitária têm papel fundamental. Nesse sentido, a então Secretaria de Cultura da Nação Argentina cria em 2011 o programa "Puntos de Cultura", no âmbito de sua Subsecretaria de Políticas Socioculturais. (ARGENTINA, 2012)

O programa argentino é explicitamente inspirado no programa brasileiro, com base em memorando de entendimento ${ }^{12}$ firmado com o MinC. Ao mesmo tempo em que incorpora especificidades da Argentina, o programa insere-se num esforço maior de consolidação de "uma política latino-americana de reconstrução do tecido social, de revalorização da identidade e de expressão popular através da cultura" (ibidem: p. 13)

\footnotetext{
${ }^{12}$ Memorando de Entendimento entre o Ministério da Cultura da República Federativa do Brasil e a Secretaria de Cultura da República Argentina, firmado em 15 de novembro de 2011, no âmbito de visita oficial da Ministra da Cultura do Brasil a Buenos Aires, onde "As Partes se propõem a intercambiar informações e cooperar na área de cidadania e diversidade cultural, especialmente no âmbito do Programa Cultura Viva, do MinC, que contempla a ação conhecida como 'Pontos de Cultura', e do Programa denominado Puntos de Cultura, da Secretaria de Cultura argentina". As ações elencadas no instrumento - com vigência de três anos (renovável), incluem cooperação, intercâmbio técnico e capacitação de recursos humanos para a "efetivação e instrumentalização do Programa argentino". Disponível na internet, em: http://v2012.cultura.gob.ar/archivos/noticias docs/Memorandum de Entendimiento.pdf
} 


\subsection{A Política Nacional de Cultura Viva No Brasil: GÊNESE E TRAJETÓRIA DE UM "MODELO"}

\subsubsection{O programa Cultura Viva: concepção e visão geral}

O Programa Nacional de Cultura, Educação e Cidadania - Cultura Viva, que congrega a rede nacional de Pontos de Cultura, foi criado em 2004 e institucionalizado como política federal em 2014, pela Lei $n^{\circ}$ 13.018/2014 - a "Lei Cultura Viva", que institui a Política Nacional de Cultura Viva. Sua implementação está a cargo do Ministério da Cultura, por meio da Secretaria da Cidadania e da Diversidade Cultural. Um dos pressupostos do programa é que o Estado tem papel importante a cumprir no estímulo e financiamento da produção de conteúdos culturais, com forte ênfase no resgate e proteção das culturas orais e do patrimônio cultural imaterial. Reforçando o fomento à utilização de novas tecnologias como base para a produção de conteúdos e expressão da diversidade cultural brasileira, o programa enfatiza ainda a importância da mobilização social e da participação cidadã, assim como do estímulo à criatividade e à produção cultural já existente. (MELO; MAKIUCHI, 2014)

Como forma inicial de definir o escopo do programa, adotarei a concepção utilizada nos próprios documentos oficiais do Ministério da Cultura do Brasil, quando do início da implementação do programa:

O programa Cultura Viva é concebido como uma rede orgânica de criação e gestão cultural, mediado pelos Pontos de Cultura, sua principal ação. A implantação do programa prevê um processo contínuo e dinâmico, e seu desenvolvimento é semelhante ao de um organismo vivo, que se articula com atores preexistentes. Em lugar de determinar (ou impor) ações e condutas locais, o programa estimula a criatividade, potencializando desejos e criando um ambiente propício para o resgate da cidadania pelo reconhecimento da importância da cultura produzida em cada localidade. (BRASIL, 2005: p. 18)

As práticas dos Pontos de Cultura são as mais variadas possíveis, mas podem ser agrupadas em algumas categorias (não-excludentes), como: desenvolvimento comunitário, cultura popular, educação, cultura digital e integração produtiva (IPEA, 2011). Suas ações vão desde o trabalho das raizeiras e a fabricação de remédios caseiros, até atividades ligadas à cultura popular, à cultura de periferia, à economia solidária, ao software livre, à produção da cultura independente e ao artesanato, "a partir de lógicas, dinâmicas e escalas muito diferentes e ideologicamente opostas à indústria cultural” (ibidem: p. 46). 
Nesse sentido, a política pública é voltada para segmentos da população de certa forma excluídos da participação na dinâmica da relação Estado-Sociedade. São segmentos para os quais o Estado brasileiro não tem tradição de destinar programas, entre eles os povos, grupos, comunidades e populações em situação de vulnerabilidade social com acesso limitado aos meios de produção e fruição cultural, ou com ameaça a sua identidade cultural ou pleno reconhecimento de seus direitos humanos, sociais e culturais.

[...] o Ponto de Cultura é “uma espécie de 'do-in' antropológico, massageando pontos vitais, mas momentaneamente desprezados ou adormecidos, do corpo cultural do País (...) "é o espaço da experimentação de rumos novos. O espaço da abertura para a criatividade popular e para as novas linguagens. $\mathrm{O}$ espaço de disponibilidade para a aventura e a ousadia. O espaço da memória e da invenção". (BRASIL, 2010a: p. 15)

Desde os documentos de criação do programa, o reconhecimento de um Ponto de Cultura representa mais que o mero apoio estatal ao fomento a determinada atividade cultural. Ao reconhecer uma iniciativa ou grupo cultural como Ponto de Cultura, busca-se reconhecêlos como os próprios sujeitos da cultura e, portanto, sujeitos da ação cultural. O programa pretende ser a "síntese da gestão compartilhada entre governo e sociedade". (BRASIL, 2005 apud MELO; MAKIUCHI, 2014: p. 8) ${ }^{13}$

"Aqui se faz cultura" pode ser um dos lemas dos Pontos de Cultura, que, ao serem reconhecidos como sujeitos, também reconhecem os outros, intensificando a troca entre si. O papel do Ministério da Cultura é agregar recursos e novas capacidades a projetos e instalações já existentes, oferecendo equipamentos que amplifiquem as possibilidades do fazer artístico e recursos para uma ação contínua junto às comunidades. (BRASIL, 2010a: p. 10)

O conceito de cultura que embasa o programa é aquele utilizado pelo Ministério da Cultura - MinC a partir de 2003, de caráter abrangente e considerando suas três dimensões: simbólica, cidadã e econômica. No campo simbólico, para o MinC, cultura representa as possibilidades de criação simbólica expressas em modos de vida, motivações, crenças religiosas, valores, práticas, rituais e identidades. A dimensão cidadã ressalta a cultura como um direito básico do cidadão, o que reflete a necessidade de políticas culturais voltadas para a garantia do acesso universal aos bens e serviços culturais, à memória e ao patrimônio artístico

${ }^{13} \mathrm{O}$ discurso do MinC incorpora a noção de que a sociedade civil e os setores culturais devem ser protagonistas, pois são eles que produzem a diversidade de expressões culturais e os conhecimentos e formas de viver que constituem a dinâmica cultural. Além disso, defende que o Estado tem grande papel de promover meios e equipamentos para universalizar a todos os brasileiros o acesso a uma cidadania plena, sendo ao mesmo tempo gestor da política cultural do País e ator garantidor de direitos culturais. (Fonte: MINC, documentos institucionais diversos). 
e histórico. No campo econômico, por sua vez, a cultura apresenta-se como parte constitutiva de um novo cenário de desenvolvimento econômico socialmente justo e sustentável, constituindo importante fonte de oportunidades de geração de ocupações produtivas e de renda. (BRASIL, 2006)

Uma das principais características do programa Cultura Viva é a multiplicidade de atores, com uma rede de mais de 4500 Pontos de Cultura, que articulam, desenvolvem atividades, produzem arte e dialogam com seus territórios (GT CULTURA VIVA, 2012). Trata-se de uma rede heterogênea, onde cada Ponto de Cultura também articula e se conecta a outras redes, podendo se configurar inclusive como um "Pontão de Cultura", que aglutina outros Pontos de Cultura.

Na concepção do programa, a constituição de uma rede de Pontos de Cultura visa a fortalecer especialmente a troca de informações entre os Pontos e a potencialização da ação de cada Ponto e da rede como um todo. Essas duas ênfases estão consubstanciadas nas diversas iniciativas de interação entre os Pontos (intercâmbios, colaboração online, eventos, debates, etc.), bem como no financiamento de aquisição de equipamentos e kits digitais (câmeras, computadores, hardware e software de gravação de áudio e vídeo), com o objetivo de “ampliar e garantir o acesso aos meios de fruição, produção e difusão cultural”. (MELO; MAKIUCHI, 2014)

O Ponto de Cultura sedimenta o Programa Cultura Viva e articula todas as demais ações. Ele é a referência de uma rede horizontal de articulação, recepção e disseminação de iniciativas e vontades criadoras. Uma pequena marca, um sinal, um ponto sem gradação hierárquica, um ponto de apoio, uma alavanca para um novo processo social e cultural. Como um mediador na relação entre Estado e sociedade, e dentro da rede, o Ponto de Cultura agrega agentes culturais que articulam e impulsionam um conjunto de ações em suas comunidades, e destas entre si. (BRASIL, 2010a: p. 14)

Na prática, o Cultura Viva é constituído de múltiplas redes, predominantemente temáticas, reunindo "coisas muito diversas, estruturas diferenciadas, relações inesperadas [...] e lógicas políticas múltiplas, direções e objetivos diferenciados" (GT CULTURA VIVA, 2012: p. 52). O programa dialoga com uma ideia de política pública que busca vitalizar os movimentos sociais no campo da cultura, "democratizando Estado e Sociedade" (ibidem: p. 54).

A cultura digital é considerada ferramenta privilegiada para comunicação entre os Pontos da rede e, ao mesmo tempo, confunde-se com a própria noção de rede preconizada pelo programa Cultura Viva, construindo "potencialmente relações políticas e sociais mais 
abertas, democráticas e horizontais" (LYRA, V.M.G. et alii in: GT CULTURA VIVA, 2012: p.52). O domínio do ciberespaço representa, para os Pontos de Cultura, uma fonte de poder social (HARVEY, 1992).

2.2.2 Evolução do programa: "afinando" e refinando os instrumentos [de gestão]

No início de sua implementação, o programa Cultura Viva amparava-se em base legal regulamentada pelas portarias do Ministério da Cultura $\mathrm{n}^{\circ} 156$, de 06 de julho de 2004; e $\mathrm{n}^{\circ}$ 82, de 18 de maio de 2005. Sob essas bases, o instrumento de parceria entre o Estado e a Sociedade no programa foi tradicionalmente a celebração de convênios. A lógica de conveniamento com os Pontos de Cultura sedimenta-se na realização de seleções públicas, ou seja, a adesão à rede de Pontos caracteriza-se como voluntária e a partir de chamamento público, por edital (BRASIL, 2010a).

$\mathrm{Na}$ primeira fase do programa, celebraram-se convênios diretos entre o MinC e os Pontos de Cultura, com duração de três anos, prevendo repasses anuais de $\mathrm{R} \$ 60.000,00$ aos Pontos, a partir de planos de trabalho pré-aprovados, totalizando $\mathrm{R} \$ 180.000,00$ para cada Ponto de Cultura.

A partir de 2007, diante da incompatibilidade entre o limitado aparato estatal (gestores, gestão e recursos financeiros) e a crescente demanda por novos editais, o programa muda sua sistemática para descentralizar a seleção, implantação e acompanhamento dos Pontos de Cultura. Destaque-se, ainda, a criação do programa Mais Cultura, que direciona uma parte significativa do orçamento do MinC para ações nas periferias dos centros urbanos e dos territórios de cidadania, ampliando também o escopo do programa Cultura Viva e o orçamento destinado aos Pontos de Cultura, inclusive a partir do Fundo Nacional de Cultura (PATURY, 2011; BARBOSA DA SILVA; 2011).

Nessa segunda fase, o Ministério da Cultura opta por descentralizar recursos para estados e municípios, que passam [estes] a ser os proponentes de convênios junto ao MinC e repassar os recursos aos Pontos, via editais regionalizados. Governos estaduais e Prefeituras municipais passam, portanto, a participar e lançar editais regionalizados para o conveniamento de novos Pontos. Institui-se também uma nova modalidade de Ponto, o "Pontão de Cultura", que passa a ser uma espécie de articulador de redes, intermediando o recebimento de recursos provenientes do governo em benefício dos Pontos. 
Com a diversificação das iniciativas de fomento e a expansão das parcerias do programa, o MinC atingiu em 2014 a marca de 4.502 Pontos de Cultura em funcionamento, ou seja, que até o final daquele ano já haviam recebido ou ainda estavam recebendo recursos provenientes do programa Cultura Viva. Cerca de 1.000 outros pontos firmaram planos de trabalho durante o ano de 2014, via redes estaduais e municipais, o que totalizaria 5.502 Pontos em funcionamento. No entanto, com a aprovação da Lei Cultura Viva em julho de 2014, os editais para o fomento aos pontos foram suspensos até a regulamentação da lei, em abril de 2015.

Cabe aqui uma nota sobre a dificuldade de se obter dados precisos sobre o número de Pontos de Cultura em atividade, bem como sobre o montante investido para o período consolidado desde 2004 até os dias atuais. Há uma profusão de números divulgados em documentos oficiais e notícias sobre o programa, sempre com enfoques diferentes, considerando esse ou aquele edital, essa ou aquela rede ou determinada localidade. Além disso, não há um sítio único na internet que concentre os dados oficiais do programa de maneira organizada, fruto das inúmeras mudanças de layout do site do MinC ao longo dos anos. Apesar do grande esforço de organização da gestão do programa na fase pós-redesenho, ainda persistem duplicidades, lacunas e inconsistências nas informações que estão disponíveis ao público em geral.

Feito esse parênteses, reproduzo abaixo os dados que se apresentaram mais completos, considerando todas as fontes acessíveis. Apenas uma pequena divergência foi encontrada no tocante ao período 2004-2012, onde alguns documentos oficiais apontam 3.662 Pontos fomentados, onde a tabela abaixo computa 3.618 Pontos. A título de descrição geral, entretanto, incongruências à parte, os números aqui expostos permitem ao leitor ter uma boa noção do tamanho do programa e das peculiaridades advindas dos diferentes modelos de fomento e de articulação em rede. Registre-se, ainda, que a meta estipulada no Plano Nacional de Cultura - PNC é atingir a casa dos "15.000 Pontos de Cultura em funcionamento [até o ano 2020], compartilhados entre o Governo Federal, as Unidades da Federação (UFs) e os municípios integrantes do Sistema Nacional de Cultura (SNC)" (PNC, Meta 23). 
TABELA 1

\begin{tabular}{|c|c|c|c|c|c|}
\hline Indicador & 2010 & 2011 & 2012 & 2013 & 2014 \\
\hline Quantidade total de Pontos de Cultura em funcionamento* & 3.452 & 3.663 & 3.675 & 4.080 & 4502 \\
\hline
\end{tabular}

Fonte: SCDC/MinC

http://pnc.culturadigital.br/metas/page/3/ Acesso em 20/03/2016

TABELA 2

\section{Plano Nacional de Cultura (PNC) - Meta 23 - Situação até 2014}

\begin{tabular}{|l|c|c|c|c|c|}
\hline Ação da Iniciativa & 2010 & 2011 & 2012 & 2013 & 2014 \\
\hline Pontão de Bens & 17 & 19 & 24 & 24 & 24 \\
\hline Pontão Direto & 126 & 126 & 126 & 126 & 126 \\
\hline Ponto de Leitura & 10 & 10 & 10 & 10 & 10 \\
\hline Ponto Direto & 601 & 601 & 601 & 601 & 601 \\
\hline Ponto Indigena & 30 & 76 & 76 & 76 & 76 \\
\hline Rede Estadual - Ponto & 1.955 & 2.115 & 2.115 & 2.515 & 2.609 \\
\hline Rede Estadual - Pontå。 & 2 & 2 & 2 & 14 & 14 \\
\hline Rede Intermunicipal - Ponto & 56 & 56 & 56 & 56 & 56 \\
\hline Rede Intermunicipal - Pontão & 1 & 1 & 1 & 1 & 1 \\
\hline Rede Municipal - Ponto & 598 & 598 & 598 & 723 & 974 \\
\hline Rede Municipal - Pontå̊ & 9 & 9 & 9 & 9 & 11 \\
\hline Total zaral & 3.405 & 3.613 & 3.618 & 4.155 & 4.502 \\
\hline
\end{tabular}

Fonte: SCDC/MinC

http:l/pnc.culturadigital.br/metas/page/3/ Acesso em 20/03/2016

Os dados acima ${ }^{14}$ mostram que as redes estadual e municipal contabilizam o maior número de Pontos de Cultura, correspondendo a $58 \%$ e $22 \%$ do total geral, respectivamente, em 2014. Isso demonstra um ganho de escala significativo a partir da mudança de estratégia do conveniamento direto para as parcerias com estados e municípios. Essa constatação

\footnotetext{
14 - Pontão de Bens: entidades conveniadas com o IPHAN com objetivo de preserver tradições culturais salvaguardadas, registradas e/ou inventariadas enquanto patrimônio immaterial brasileiro. - Pontão Direto: articulam os Pontos de Cultura, difundem açóes e trabalham para integração da rede, sendo conveniados diretamente com o MinC.

- Ponto Direto: conveniados diretamente com o minC.

- Ponto de Rede (estadual, municipal e intermunicipal): entidades selecionadas em editais realizados pelos estados ou municípios, que mantém convênios com o MinC para implantação de Redes de Pontos de Cultura.

- Ponto Indígena: entidades selecionadas por meio de edital para implantação de Pontos de Cultura Indígenas. Ação realizada em parceria entre MinC e FUNAI.
} 
corrobora a opinião de alguns analistas sobre a importância do fortalecimento da cooperação federativa para o alcance da meta estabelecida no Plano Nacional de Cultura (BARBOSA E SILVA e LABREA, 2014). A alternativa da certificação de Pontos por meio da autodeclaração - a ser discutida mais adiante - também poderá auxiliar o alcance da meta.

Quanto à distribuição regional, os Pontos e Pontões estão distribuídos nas 27 unidades da federação, incluindo o Distrito Federal. Conforme dados do Relatório de Gestão 2012 da SCDC, a distribuição dos Pontos e Pontões de Cultura nos estados brasileiros foi a seguinte, considerando o acumulado do período de 2004 a 2012: 
TABELA 3

Pontos e Pontões de Cultura

Distribuição por Unidade da Federação - Acumulado 2004-2012 ${ }^{15}$

\begin{tabular}{ccccc}
\hline UF & $\begin{array}{c}N^{\circ} \text { de } \\
\text { PONTOS }\end{array}$ & $\begin{array}{c}N^{\circ} \text { de } \\
\text { PONTÕES }\end{array}$ & TOTAL & PESO (\%) \\
\hline AC & 26 & 2 & 28 & $0,76 \%$ \\
AL & 72 & 4 & 76 & $2,07 \%$ \\
AM & 44 & - & 44 & $1,20 \%$ \\
AP & 17 & 1 & 18 & $0,49 \%$ \\
BA & 373 & 3 & 376 & $10,26 \%$ \\
CE & 240 & 10 & 250 & $6,83 \%$ \\
DF & 64 & 28 & 92 & $2,51 \%$ \\
ES & 33 & 3 & 36 & $0,98 \%$ \\
GO & 83 & 3 & 86 & $2,35 \%$ \\
MA & 74 & - & 74 & $2,02 \%$ \\
MG & 192 & 6 & 198 & $5,41 \%$ \\
MS & 60 & 2 & 62 & $1,69 \%$ \\
MT & 47 & 3 & 50 & $1,37 \%$ \\
PA & 75 & 2 & 77 & $2,10 \%$ \\
PB & 66 & 3 & 69 & $1,88 \%$ \\
PE & 161 & 8 & 169 & $4,61 \%$ \\
PI & 111 & 3 & 114 & $3,11 \%$ \\
PR & 116 & 3 & 119 & $3,25 \%$ \\
RJ & 441 & 21 & 462 & $12,61 \%$ \\
RN & 67 & 1 & 68 & $1,86 \%$ \\
RO & 33 & 1 & 34 & $0,93 \%$ \\
RR & 19 & 1 & 20 & $0,55 \%$ \\
RS & 261 & 6 & 267 & $7,29 \%$ \\
SC & 88 & 3 & 91 & $2,48 \%$ \\
SE & 38 & 1 & 39 & $1,06 \%$ \\
SP & 665 & 40 & 705 & $19,25 \%$ \\
TO & 39 & - & 39 & $1,06 \%$ \\
Total & 3.505 & 158 & 3.663 & $100 \%$ \\
\hline
\end{tabular}

Fonte: SCDC/MinC apud BRASIL (2013b: pp. 9-10)

Elaboração do autor.

\footnotetext{
${ }^{15}$ Os dados desta tabela referentes ao número de Pontos e Pontões foram constam do relatório de acompanhamento da CGU (BRASIL, 2013b), com base no Relatório de Gestão da SCDC de 2012. O total (3.663) difere do apresentado nas tabelas anteriores para o ano 2012, que era de 3.618. Dada a dificuldades de obtenção de dados mais atualizados organizados de forma semelhante, desconsideramos essa pequena diferença, por entender que não prejudica a visualização geral da distribuição dos Pontos no território nacional no período acumulado - objetivo primordial da tabela.
} 
Conforme se pode observar, apenas nove estados (Bahia, Ceará, Minas Gerais, Pernambuco, Piauí, Paraná, Rio de Janeiro, Rio Grande do Sul e São Paulo) haviam ultrapassado a marca dos 100 Pontos e Pontões até 2012. Juntos, esses estados contabilizavam mais de 72,6\% do total de Pontos e Pontões. Se considerados apenas os números de Pontões, entretanto, destacam-se Ceará, DF, Rio de Janeiro e São Paulo. Quanto à distribuição por regiões do País, os números mostram praticamente uma equivalência entre as regiões nordeste e sudeste, contabilizando respectivamente $34 \%$ e $38 \%$ do total - o que demonstra o resultado de um esforço mais geral de desconcentração regional dos recursos destinados ao apoio e fomento à cultura no País. ${ }^{16}$

FIGURA 1

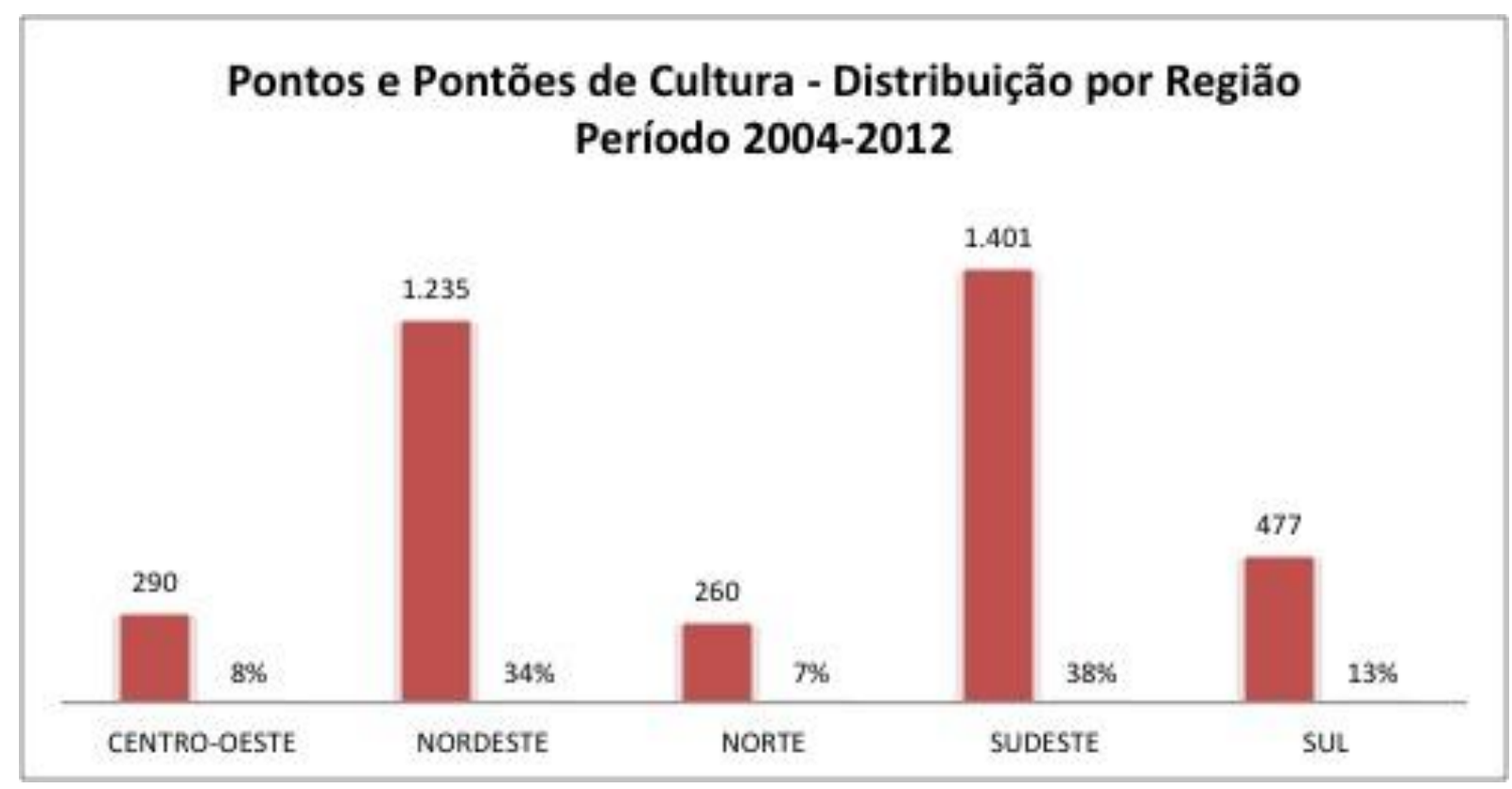

Fonte: SCDC/MinC (BRASIL, 2013b)

Elaboração do autor.

\footnotetext{
${ }^{16}$ A concentracão de recursos de apoio e fomento à cultura nas regiões Sul e Sudeste é um dos problemas crônicos no histórico da política cultural brasileira. O esforço de democratização do acesso ao fomento e de redistribuição dos investimentos destinados à cultura foi uma política deliberada, desde 2003, com vistas a combater desigualdades históricas e sua reprodução nos mecanismos de renúncia fiscal pela Lei Rouanet (BRASIL, 2010b). Além disso, a própria essência do programa Cultura Viva e o conceito de Pontos de Cultura favorecem a valorização dos "fazedores de cultura" nos rincões do Brasil profundo, em especial no nordeste, onde as raízes da cultura brasileira estão fincadas, e onde se faz cultura desde sempre, muito antes da chegada do apoio estatal.
} 
Conforme se verifica no gráfico abaixo, o número de Pontos em funcionamento ficou praticamente estagnado entre 2010 e 2012, voltando a crescer em apenas em 2013 e 2014:

FIGURA 2

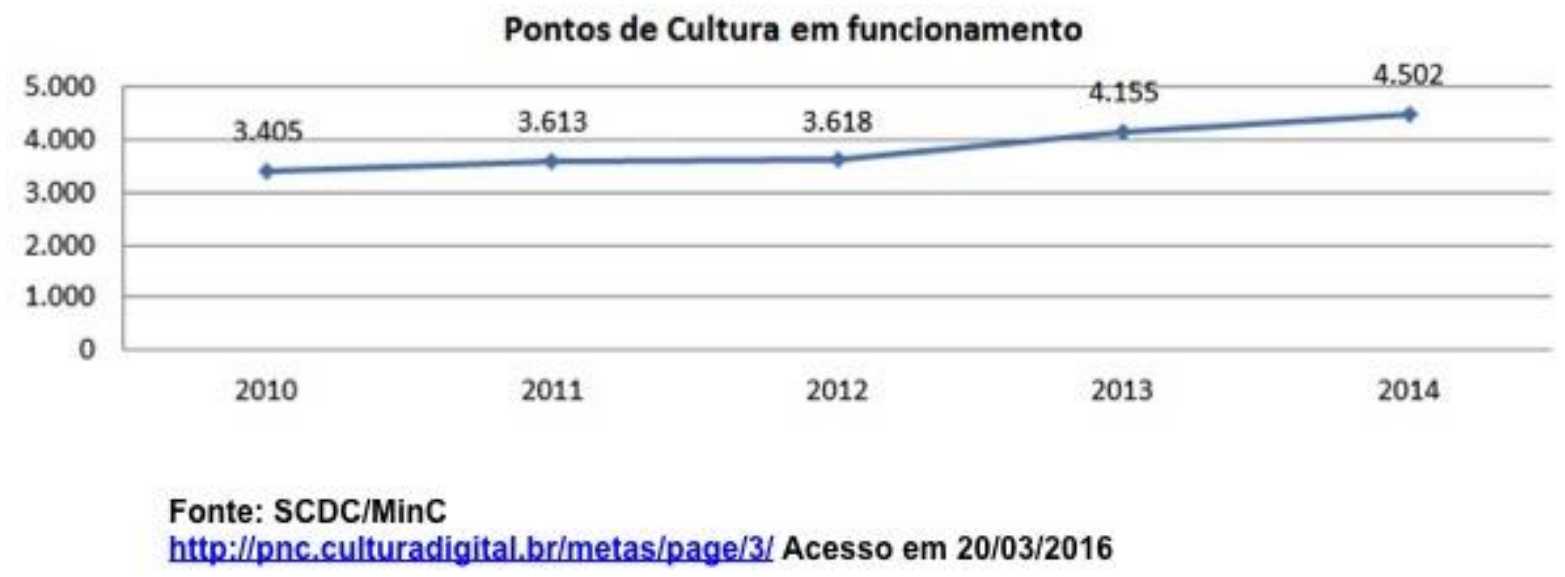

Destaque-se que, em 2010, o Ministério da Cultura firma parceria com o Instituto de Pesquisa Econômica Aplicada (IPEA), com vistas à realização de estudos e pesquisas sobre temas concernentes às políticas públicas de cultura. $\mathrm{O}$ resultante Acordo de Cooperação $\mathrm{n}^{\circ}$ 32/2010 viabilizou não apenas atividades para subsidiar, institucionalizar e aprimorar as ações de continuidade do Programa Cultura Viva, como também resultou na criação de um grupo de trabalho (posteriormente instituído pela Portaria MinC n. ${ }^{\circ}$ 45, de 19/04/2012), para discutir e elaborar o redesenho do Programa Cultura Viva.

Após o redesenho do programa, em 2012, diante da multiplicidade de atores e instrumentos envolvidos, o MinC se volta para a qualificação e ampliação dos instrumentos de fomento utilizados - como bolsas, prêmios, contratos e convênios -, buscando o aperfeiçoamento da gestão institucional do programa e a constituição de um novo marco regulatório, que se consubstancia com a aprovação da Lei Cultura Viva. (ROLLEMBERG, 2014)

Com vistas a melhor compreender a evolução do programa Cultura Viva e as ênfases dadas pelo MinC ao programa, vale recorrer aqui, em caráter de síntese, à sistematização de 
ROLLEMBERG (2014) ${ }^{17}$ sobre as diferentes etapas do programa, considerando seus principais objetivos durante o período 2004-2014:

${ }^{17}$ Márcia Rollemberg foi Secretária da Cidadania Cultural (SCC/MinC) e posteriormente Secretária de Cidadania e Diversidade Cultural (SCDC/MinC), entre outubro de 2011 e dezembro de 2014, durante as gestões das Ministras da Cultura Ana de Hollanda e Marta Suplicy no Ministério da Cultura. Foi sucedida por Ivana Bentes, que assumiu a SCDC na segunda gestão do Ministro Juca Ferreira no MinC, a partir de janeiro de 2015. 
TABELA 4

Etapas do Programa Cultura Viva - PCV

\begin{tabular}{|c|c|c|c|c|}
\hline PERÍODO & $\begin{array}{c}\text { 1a ETAPA } \\
2004-2006\end{array}$ & $\begin{array}{c}\text { 2a ETAPA } \\
2007-2010\end{array}$ & $\begin{array}{c}\text { 3a ETAPA } \\
2011-2012\end{array}$ & $\begin{array}{c}\text { 4a ETAPA } \\
\text { 2013-2014 }\end{array}$ \\
\hline FOCO & $\begin{array}{l}\text { FORMULAÇÃO E } \\
\text { IMPLEMENTAÇÃO }\end{array}$ & $\begin{array}{l}\text { EXPANSÃO } \\
\text { FEDERATIVA }\end{array}$ & $\begin{array}{l}\text { REESTRUTURAÇÃO E } \\
\text { FORTALECIMENTO } \\
\text { DA GESTÃO }\end{array}$ & $\begin{array}{l}\text { CONSOLIDAÇÃO DO PCV } \\
\text { COMO POLÍTICA DE BASE } \\
\text { COMUNITÁRIA DO GOVERNO }\end{array}$ \\
\hline $\begin{array}{l}\text { OBJETI- } \\
\text { VOS }\end{array}$ & $\begin{array}{l}\text { - Promoção da } \\
\text { produção, da } \\
\text { pesquisa, do } \\
\text { registro e da } \\
\text { difusão das } \\
\text { expressões } \\
\text { culturais dos } \\
\text { grupos e } \\
\text { entidades } \\
\text { responsáveis } \\
\text { pelos modos de } \\
\text { ser, pensar e fazer } \\
\text { cultural no País, } \\
\text { potencializando as } \\
\text { iniciativas } \\
\text { existentes nas } \\
\text { comunidades; } \\
\text { Criação de uma } \\
\text { nova forma de } \\
\text { atuação do MinC, } \\
\text { considerando a } \\
\text { participação social } \\
\text { e a gestão } \\
\text { compartilhada. } \\
\text { - Definição de focos } \\
\text { específicos para } \\
\text { os mecanismos de } \\
\text { aporte de } \\
\text { recursos além da } \\
\text { Lei Rouanet } \\
\text { (renúncia fiscal); } \\
\text { Execução direta } \\
\text { do MinC com a } \\
\text { sociedade civil. } \\
\text { Mobilização e } \\
\text { articulação, da } \\
\text { Rede com } \\
\text { comticipação social } \\
\text { compartilhada; }\end{array}$ & 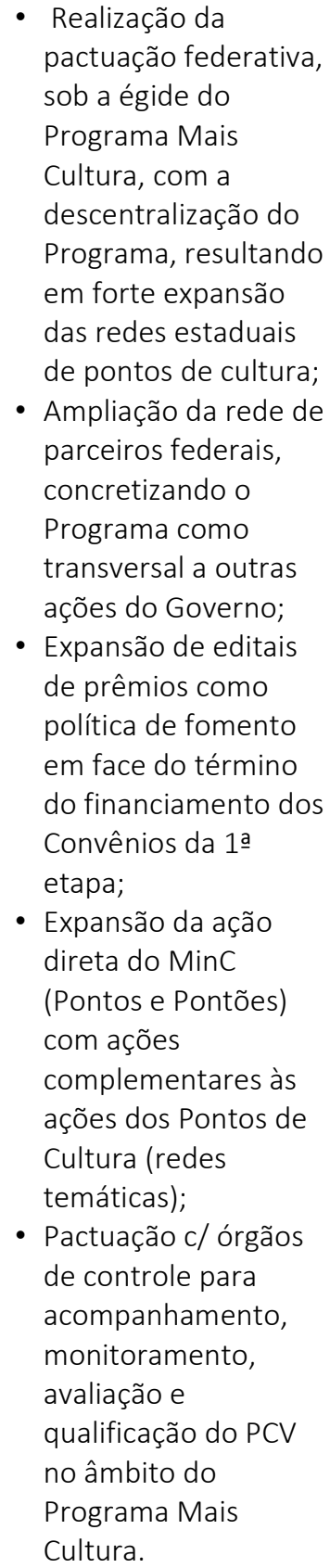 & $\begin{array}{l}\text { - Planejamento } \\
\text { de ações } \\
\text { prioritárias e de } \\
\text { saneamento de } \\
\text { problemas para } \\
\text { qualificar a } \\
\text { gestão e honrar } \\
\text { os } \\
\text { compromissos } \\
\text { assumidos; } \\
\text { Diagnóstico e } \\
\text { redesenho do } \\
\text { PCV, } \\
\text { considerando a } \\
\text { junção dos } \\
\text { Programas } \\
\text { Cultura Viva e } \\
\text { Brasil Plural. } \\
\text { Definição da } \\
\text { diversidade } \\
\text { como matriz na } \\
\text { promoção da } \\
\text { cidadania } \\
\text { cultural, com } \\
\text { início da } \\
\text { articulação da } \\
\text { Rede Cultura } \\
\text { Viva com outras } \\
\text { redes } \\
\text { convergentes. } \\
\text { dos } \\
\text { compromissos } \\
\text { orçamentários e } \\
\text { financeiros. } \\
\text { pampliação da } \\
\text { órgãos de } \\
\text { controle } \\
\text { Manutenção } \\
\text { parceria com } \\
\text { doão e }\end{array}$ & 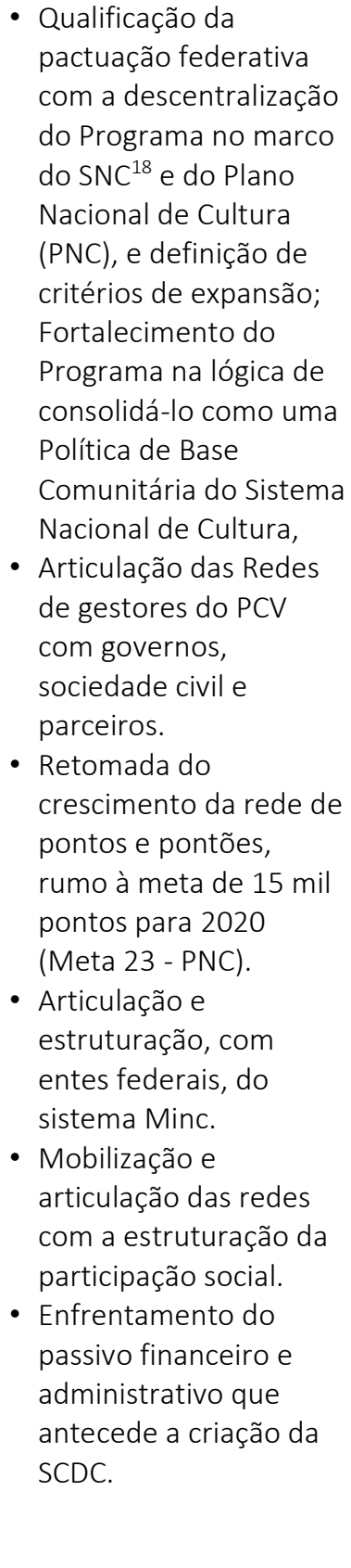 \\
\hline
\end{tabular}

Fonte: ROLLEMBERG (2014: p. 2) ${ }^{19}$

${ }^{18}$ SNC - Sistema Nacional de Cultura

${ }^{19}$ A sistematização aqui reproduzida foi elaborada por Rollemberg (2014) e, portanto, espelha a visão da então Secretária da SCDC/MinC sobre a evolução do programa. Não obstante, em que pese a possibilidade de um viés oficial à narrativa dessa evolução, o quadro apresentado busca ilustrar de forma resumida as diferentes ênfases do programa Cultura Viva durante seus 10 primeiros anos de 
Cabe ressaltar que, em 2011, ao mesmo tempo em que o programa passava por uma revisão, a partir das conclusões de avaliação conduzida pelo IPEA no ano anterior (BARBOSA DA SILVA e ARAÚJO, 2010), enfrentava crises internas na sua gestão e financiamento. É nesse contexto que o Projeto de Lei n. 757/2011 é apresentado na Câmara dos Deputados, para criação da Política Nacional de Cultura Viva. Após tramitar por 3 anos, o PL é finalmente aprovado em junho de 2014, e sancionado em julho do mesmo ano, passando a vigorar na forma da Lei no 13.018 - batizada de "Lei Cultura Viva".

São objetivos da Política Nacional de Cultura Viva (Lei no 13.018/2014, com grifos deste autor):

I - garantir o pleno exercício dos direitos culturais aos cidadãos brasileiros, dispondo-lhes os meios e insumos necessários para produzir, gerir e difundir iniciativas culturais;

II - estimular o protagonismo social na elaboração e na gestão das políticas públicas;

III - promover uma gestão pública compartilhada e participativa, amparada em mecanismos democráticos de diálogo com a sociedade civil;

IV - consolidar os princípios da participação social nas políticas culturais;

V - garantir o respeito à cultura como direito de cidadania e à diversidade cultural como expressão simbólica e como atividade econômica;

VI - estimular iniciativas culturais já existentes, por meio do apoio financeiro da União, dos Estados, do Distrito Federal e dos Municípios;

VII - promover o acesso aos meios de fruição, produção e difusão culturais;

VIII - potencializar, com educação, iniciativas culturais, visando à construção de novos valores de cooperação e solidariedade, e ampliar instrumentos de educação;

IX - estimular a exploração, uso e apropriação dos códigos, linguagens artísticas e espaços públicos e privados disponibilizados para a ação cultural.

implementação. Nesse sentido, o uso dos adjetivos "qualificação" e "fortalecimento", na coluna referente à 4a etapa, deve ser relativizado - uma vez que é utilizado pela própria gestora do programa. Não aprofundaremos aqui a discussão sobre a pertinência ou não desses termos, visto que neste ponto o intuito é apenas de facilitar a compreensão da evolução das diversas etapas do programa. 
Apesar de aprovada em 2014, a Lei Cultura Viva - que institui a Política Nacional de Cultura Viva - só passa a vigorar plenamente em 2015, a partir de sua regulamentação pela Instrução Normativa (IN) $N^{0} 01$, de 07 de abril de 2015. O processo de construção da IN foi colaborativo, contando com a participação de representantes do governo e da sociedade civil, notadamente do Ministério da Cultura e dos Pontos de Cultura, respectivamente.

A nova etapa do Cultura Viva inaugurada em 2015, já sob a égide de uma Política Nacional - e não meramente de um programa - incorpora novos conceitos e instrumentos, além de uma dinâmica diferenciada. O mote da SCDC passa a ser a intensificação de uma "cultura de rede", com maior aproximação com os movimentos socioculturais, investindo na expansão da rede de Pontos de Cultura a partir da possibilidade da "autodeclaração", onde os Pontos passam a ser reconhecidos pelo MinC independentemente de terem ou não uma relação contratual com o Estado. (BENTES, 2015)

Estamos falando de movimentos que surgem pós-redistribuição de renda,
que não demandam simplesmente recursos, mas políticas de sustentação e
ativação de narrativas, "commons" e bens simbólicos, entendendo que a
transferência de renda apenas [por si só] não acaba com as desigualdades. O
desafio é dar suporte e criar políticas para essas redes socioculturais que se
reinventaram após a conquista mínima de direitos. [...]
[...] Entendemos a cultura de rede como um processo de construção conjunta
de redes de cultura (redes de Povos de Terreiro, redes de mídia livre, redes
do funk, redes de produtores e agentes culturais, etc.). Arranjos e articulação
em redes são uma nova capa de construção do campo expandido da cultura,
capaz de rivalizar com a indústria cultural e de fazer as disputas narrativas. É
dentro dessa política, na Secretaria que faz a articulação da Cidadania com a
Diversidade (SCDC do MinC), que vemos emergir um novo desenho, para
além dessa "fragmentação de círculos e pontos, a cultura de redes como
estruturante de uma nova política cultural indutora de uma nova base social,
que parte da cultura. (BENTES, 2015: p. 2; 4)

No plano administrativo, há que se apontar duas inovações da Lei Cultura Viva, cuja operação é detalhada na IN 01/2015: a instituição de um Cadastro Nacional de Pontos e Pontões e a instituição do Termo de Compromisso Cultural (TCC). O primeiro tem o intuito de ser um cadastro permanente de instituições elegíveis para parcerias, incluindo os Pontos de Cultura autodeclarados. O segundo apresenta-se como um novo regime jurídico de parceria entre governo e sociedade, de caráter simplificado e adaptado às características das entidades culturais, com teto definido para repasses de recursos.

A IN 01/2015 estabelece, no seu Art. $21 \S 6^{\circ}$, os seguintes tetos para os repasses a 
Pontos e Pontões de Cultura via TCC:

I - para Pontos de Cultura: valor total do repasse de até R $\$ 360.000,00[\ldots]$ e valor da parcela anual de até $\mathrm{R} \$ 120.000,00[\ldots]$; e

II - para Pontões de Cultura: valor total do repasse de até R\$ 2.400.000,00 [...] e valor da parcela anual de até $\mathrm{R} \$ 800.000,00[\ldots]$.

\subsubsection{Funcionamento e lógica de operação do programa20}

Com o intuito de facilitar a posterior comparação com o programa argentino Puntos de Cultura - a ser analisado na seção seguinte deste capítulo, passaremos agora a uma descrição sucinta de algumas características básicas do funcionamento e da lógica de operação do programa Cultura Viva.

\section{Requisitos}

Os requisitos para participação no programa Cultura Viva foram sendo modificados ao longo do tempo, porém sua base está na existência prévia de atividade cultural desenvolvida por entidade, grupo ou coletivo de qualquer natureza. Quanto aos requisitos para conveniamento dos Pontos de Cultura com o Governo, seja com o Ministério da Cultura ou com entes estaduais ou municipais - especialmente nas etapas do programa até 2014 - cabe ressaltar que os Pontos tinham que preencher todos os requisitos formais necessários ao estabelecimento de um Convênio, regido pelas normas e regras associadas à celebração de parcerias entre entidades privadas sem fins lucrativos e órgãos governamentais. $\mathrm{O}$ ônus de apresentar documentação adequada e Plano de Trabalho devidamente preenchido e pactuado, bem como de outros documentos eventualmente exigidos nos editais de chamamento público, nesse caso, recai sobre o Ponto de Cultura, estabelecido como Pessoa Jurídica.

Conforme a concepção inicial do programa, algumas modalidades de ações do Cultura Viva abrigavam a possibilidade de engajamento de Pessoas Física, sem a necessidade de constituição de Pessoa Jurídica, como por exemplo a ação Griô, por meio de recebimento de bolsas outorgadas por meio de entidades que firmavam parceria com o MinC.

O mecanismo da Autodeclaração, instituído a partir da Lei Cultura Viva, possibilita o reconhecimento como Ponto de Cultura a partir da simples adesão ao Cadastro Nacional de

\footnotetext{
${ }^{20}$ A informações sobre o funcionamento do programa aqui expostas foram sistematizadas a partir dos dados constantes em documentos oficiais do Ministério da Cultura (BRASIL, 2005; BRASIL, 2010a; BRASIL 2015), bem como em informações na internet - site do MinC (http://www.cultura.gov.br/cultura-viva1 e site da Semana Cultura Viva - Cultura Viva 10 Anos http://semanaculturaviva.cultura.gov.br/linhadotempo/index.html )
} 
Pontos e Pontões de Cultura, com posterior certificação por comissão paritária (composta por representantes do governo e da sociedade). O processo seletivo é simplificado, aberto permanentemente e em fluxo contínuo, desde que preenchidos os seguintes requisitos ${ }^{21}$ :

I - Ser pessoa jurídica de direito privado sem fins lucrativos, ou coletivo cultural sem constituição jurídica, de natureza ou finalidade cultural, que desenvolva e articule atividades culturais em suas comunidades;

II - Comprove, no mínimo, 1 (um) ano de existência e desenvolvimento de atividade culturais, através de fotos, material gráfico de eventos, publicações impressas e em meios eletrônicos e outros materiais comprobatórios;

III - Que tenha o apoio, por meio de cartas de reconhecimento, de no mínimo 2 (dois) Pontos de Cultura, instituições públicas, privadas, coletivos culturais ou comunidades, com ou sem constituição jurídica, relacionados à arte, cultura, educação ou desenvolvimento comunitário. As cartas devem ser assinadas e digitalizadas. Serão aceitas somente assinaturas manuscritas em papel ou impressões digitais em caso de pessoas não alfabetizadas. Não serão aceitas assinaturas digitais.

IV - Preencha as informações de Cadastro na Plataforma Rede Cultura Viva e aceite os Termos de Uso e o Termo de Adesão à Política Nacional de Cultura Viva.

\section{Difusão e publicização dos editais (convocatórias)}

A adesão à rede de Pontos de Cultura é voluntária, independentemente do formato do instrumento de adesão. Até meados de 2015, a única forma de adesão era por editais ou chamadas públicas voltadas para o acesso a algum tipo de fomento ou apoio financeiro do Estado. Os editais promovidos pelo Ministério da Cultura são de caráter aberto e de alcance nacional. Nos casos de parcerias com estados e/ou municípios, são firmados convênios entre o ministério e os entes federados, os quais realizam seleções públicas locais.

Além de utilizar os canais tradicionais de divulgação, o ministério também realiza oficinas regionais e estaduais de orientação direcionadas aos potenciais interessados em participar dos editais, bem como coloca sua equipe à disposição para atendimentos diversos e plantões para esclarecimento de dúvidas.

Com a instituição do mecanismo de Autodeclaração, a partir da Lei Cultura Viva, o MinC lança em outubro de 2015 a Plataforma Rede Cultura Viva ${ }^{22}$. A plataforma permite tanto a difusão quanto a captação de informações sobre os Pontos de Cultura e as entidades e coletivos culturais que desejam incorporar-se ao programa pelo mecanismo da

\footnotetext{
${ }^{21}$ Fonte: http://culturaviva.gov.br/saiba-mais/\#quais-os-criterios. Acesso em 03 mar. 2016.

${ }^{22}$ Para acessar a Plataforma Rede Cultura Viva: http://culturaviva.gov.br/rede/. Para informações sobre o lançamento http://pnc.culturadigital.br/2015/10/06/ministro-juca-ferreira-lanca-plataforma-darede-cultura-vival. Acesso em 02 mar. 2016.
} 
autodeclaração. A partir das informações fornecidas pelos próprios Pontos, pretende-se constituir um novo mapa dos Pontos por meio da plataforma (ABERTURA, 2016).

\section{Critérios de elegibilidade}

De forma geral, nas primeiras etapas do programa Cultura Viva, buscou-se incorporar uma amplitude de propostas que refletissem a diversidade de manifestações culturais brasileiras, incorporando referencias simbólicas e linguagens artísticas no processo de construção da cidadania, potencializando energias sociais e culturais e fomentando a ativação uma rede horizontal de "transformação, de invenção, de fazer e refazer" (BRASIL, 2010a: p. 11).

Nesse sentido, considerando o espectro conceitual abrangente do programa, a natureza da atividade de cada Ponto de Cultura importa menos do que sua perspectiva de desenvolver trabalho em rede, de conectar-se, de intercambiar saberes e práticas. O programa observa, ainda, como critério de priorização, o grau de aderência das atividades do Ponto (ou candidato a Ponto) com o desenvolvimento da autonomia, do protagonismo e do empoderamento social dos grupos culturais e indivíduos nas comunidades onde se inserem.

Em princípio, como não há modelo único para o Ponto de Cultura, são elegíveis quaisquer iniciativas ligadas à cultura de base comunitária, indígenas, quilombolas, de matriz africana, economia solidária, produção cultural urbana e das periferias, cultura digital ou cultura popular, abrangendo todos os tipos de linguagem artística e cultural, em todo o território nacional. O público-alvo prioritário contempla todas as faixas etárias, porém há uma maior incidência sobre adolescentes e jovens adultos que protagonizam ações culturais em suas comunidades. Outra faixa de priorização é de populações de baixa renda e habitantes de áreas com oferta precária de serviços públicos, bem como agentes culturais, artistas produtores e educadores que desenvolvem ações de combate à exclusão social e cultural. (BRASIL, 2010a)

No formato inicial do programa, como a forma de relação com o Estado é o convênio, o atendimento às exigências documentais e de natureza jurídica das organizações torna-se, inevitavelmente, um dos critérios de elegibilidade obrigatórios do programa.

Com o instituto da Lei Cultura Viva, as próprias definições do que são Pontos e Pontões de Cultura já pré-definem alguns requisitos, como a natureza ou finalidade cultural 
ou educativa, articulação de atividades culturais nas comunidades e potencial de mobilização. A grande novidade da Lei, entretanto, nesse quesito, é a possibilidade de adesão de "grupos ou coletivos sem constituição jurídica, de natureza ou finalidade cultural". No caso dos Pontões, o principal critério de elegibilidade é a vocação para ativação, articulação e mobilização de redes regionais, identitárias e temáticas de Pontos. Conforme explicitado no artigo $4^{\circ}$ da Lei 13.018, que institui a Política Nacional de Cultura Viva, entende-se por Pontos e Pontões:

I - pontos de cultura: entidades jurídicas de direito privado sem fins lucrativos, grupos ou coletivos sem constituição jurídica, de natureza ou finalidade cultural, que desenvolvam e articulem atividades culturais em suas comunidades;

II - pontões de cultura: entidades com constituição jurídica, de natureza/finalidade cultural e/ou educativa, que desenvolvam, acompanhem e articulem atividades culturais, em parceria com as redes regionais, identitárias e temáticas de pontos de cultura e outras redes temáticas, que se destinam à mobilização, à troca de experiências, ao desenvolvimento de ações conjuntas com governos locais e à articulação entre os diferentes pontos de cultura que poderão se agrupar em nível estadual e/ou regional ou por áreas temáticas de interesse comum, visando à capacitação, ao mapeamento e a ações conjuntas;

\section{Instrumentos de apoio ao Processo de Seleção}

Como já mencionado, o convênio é adotado inicialmente como principal instrumento de parceria entre o Ministério da Cultura e os Pontos de Cultura; numa segunda fase, quando se observa a multiplicidade de atores envolvidos, o Ministério opta por descentralizar recursos para estados e municípios, que passam [estes] a ser os proponentes de convênios junto ao MinC e repassar os recursos aos Pontos, via editais regionalizados.

Numa terceira fase, um modelo híbrido é adotado, onde surge a figura do Pontão de Cultura. Na sua concepção, o Pontão é apresentado como uma espécie de articulador junto aos demais Pontos, inclusive para intermediar o recebimento de recursos provenientes do governo em benefício dos Pontos. Ou seja, convênios e editais passam a ser adotados de forma diferenciada, com atores e beneficiários de natureza diversa. Não há elementos, entretanto, para afirmar se esse papel de articulação foi plenamente alcançado. 
Por último, após o redesenho do programa Cultura Viva, em 2012, o MinC se volta para a qualificação e ampliação dos instrumentos de fomento utilizados- como bolsas, prêmios, contratos e convênios (ROLLEMBERG, 2014)

Com a aprovação da Lei Cultura Viva, em 2014, institui-se o Cadastro Nacional de Pontos e Pontões de Cultura - consubstanciado na Plataforma Rede Cultura Viva (Autodeclaração) - e o Termo de Compromisso Cultural, instrumentos que pretendem dar um caráter de simplificação à certificação dos Pontos e maior fluidez na relação dos Pontos com o Estado. Cabe ressaltar, entretanto, que o Cadastro Nacional foi concebido no sentido de organizar os bancos de dados do programa, não necessariamente limitando o acesso a recursos.

Art. $4^{\circ}$ A Política Nacional de Cultura Viva compreende os seguintes instrumentos: [...]

III - Cadastro Nacional de Pontos e Pontões de Cultura: integrado pelos grupos, coletivos e pessoas jurídicas de direito privado sem fins lucrativos que desenvolvam ações culturais e que possuam certificação simplificada concedida pelo Ministério da Cultura. [...]

Art $9^{\circ}$ A União, por meio do Ministério da Cultura e dos entes federados parceiros, é autorizada a transferir de forma direta os recursos às entidades culturais integrantes do Cadastro Nacional de Pontos e Pontões [...].

$\S 1^{\circ}$ A transferência dos recursos [...] ficará condicionada ao cumprimento de Termo de Compromisso Cultural, que deverá conter a identificação e a delimitação das ações a serem financiadas, as metas, o cronograma de execução físico-financeira e a previsão de início e término da execução das ações ou das fases programadas. [...] (Lei n. 13.018/2014)

Cabe sublinhar, ainda, a coexistência de vários formatos de instrumentos de seleção pública, como: editais nacionais e estaduais para constituição das redes de Pontos e/ou Pontões, associados ao Sistema Nacional de Cultura; editais nacionais de premiação de experiências; e editais de boas práticas de gestão em município. (BRASIL, 2015)

\section{Etapas do Programa}

No primeiro formato do programa, que se constituiu na seleção por editais para celebração de convênio direto com o MinC - entre 2004 e 2007 - suas etapas assimilavam-se às fases do próprio processo de conveniamento, ou seja: inscrição de propostas; seleção pública de propostas; apresentação de documentação e aprovação do Plano de Trabalho; assinatura do convênio; implementação (sob monitoramento do MinC); e prestação de contas.

Nesse modelo, um Ponto de Cultura só passava a ser chamado como tal quando recebia a chancela formal do Ministério da Cultura, por meio da assinatura de Termo de 
Convênio, com duração de três anos. A etapa de implementação apresentava, portanto, um desafio em si, dada a necessidade de acompanhamento das atividades e monitoramento do cumprimento do Plano de Trabalho.

Como apontam BARBOSA DA SILVA e LABREA (2014), o ano de 2007 marcou o início de uma crise no programa, com a finalização dos primeiros convênios e problemas decorrentes do atraso na liberação de recursos, contingenciamento e a não aprovação dos relatórios de prestação de contas de vários Pontos. Uma das saídas para dar continuidade aos trabalhos já iniciados foi adotar a modalidade de prêmios, ao invés de convênios (ibidem). Nessa nova modalidade, as etapas encerram-se na outorga do prêmio, uma vez que não há necessidade de cumprimento de plano de trabalho específico e, portanto, de monitoramento e prestação de contas.

Em paralelo, o programa incorporou as ações do programa Mais Cultura e buscou ganhar escala, passando a adotar a lógica federativa e introduzindo os repasses de recursos via convênio para Estados e Municípios, os quais passaram a fazer seleções públicas para conveniamento com os Pontos de Cultura nos territórios. Com a introdução dessa lógica de ação, o programa ultrapassa o montante de 3 mil pontos fomentados e mais de 3,6 mil pactuados até o ano 2012 (BARBOSA DA SILVA e LABREA, 2014: p. 7) .

Nesse modelo, as etapas se distinguem quanto aos atores envolvidos, ou seja: na relação entre ministério e entes federativos; e na relação entre estados/municípios e os Pontos. O instrumento utilizado em ambos os casos também é o convênio - o MinC firma convênio um determinado ente federativo e este faz o processo seletivo, firmando em seguida convênios com os Pontos selecionados. As atividades de monitoramento são compartilhadas, bem como a análise de prestação de contas.

Com a introdução do mecanismo da autodeclaração, a partir de 2015-2016, introduz-se uma nova etapa, que é a da "Certificação Simplificada" como Ponto ou Pontão de Cultura. Trata-se de um processo seletivo simplificado, a partir de um cadastro aberto na plataforma Rede Cultura Viva, seguido de avaliação por comissão paritária composta por membros do governo e da sociedade civil, com base nos critérios já explicitados acima no item "requisitos".

O início desse processo, entretanto, não deixa de ter suas complexidades (informação verbal $)^{23}$, especialmente pela necessidade de uma nova pactuação de objetivos e expectativas em relação ao papel que os novos Pontos certificados passam a exercer na rede nacional do

\footnotetext{
${ }^{23}$ Entrevista VIII [março 2016].
} 
Pontos de Cultura, diante da ausência do fomento como elemento estruturante do programa. Como esses novos Pontos recebem a chancela do MinC sem necessariamente receber apoio direto com recursos financeiros, a etapa da certificação torna-se central no processo de reconhecimento. A partir da experiência-piloto realizada em março de 2016, observou-se que a etapa anterior - de preenchimento do cadastro na plataforma - merece atenção especial, com vistas a melhorar a qualidade da informação disponibilizada para a comissão de certificação (informação verbal) $)^{24}$.

Por fim, vale destacar a existência de algumas etapas processuais importantes, como visitas técnicas de acompanhamento de convênios, reuniões in loco com representantes de Pontos e membros das comunidades, além das visitas e atividades relacionadas à prestação de contas (BRASIL, 2015). Nota-se, entretanto, que não há um padrão determinado para essas atividades, o que dificulta uma análise mais detida sobre o real impacto das mesmas no âmbito do programa. Como apontam Barbosa da Silva e Labrea (2014: p. 103) sobre os problemas e desafios enfrentados pelo programa, há duas visões complementares a serem consideradas:

Em uma perspectiva instrumental, mais ligada à relação de meios e fins, típicas da administração, dir-se-ia que o programa convive com dificuldades em selecionar formas organizacionais e alocar recursos de maneira racional e segundo critérios explícitos. [...]

Em outra perspectiva mais compreensiva, mais ligada aos processos de mobilização social, ao encantamento coletivo e à produção de significados alternativos no campo das políticas, se diria que o programa é completamente exitoso e que gerou uma rede imensa de atores mobilizados para produzir cultura e promover a diversidade cultural.

2.2.4 A gestão dos instrumentos: uma teia de desafios e adaptações

Os instrumentos e ferramentas inerentes ao programa Cultura Viva, desde sua concepção inicial, podem ser agrupados conforme o quadro a seguir :

TABELA 5

Instrumentos e ferramentas do Programa Cultura Viva

\begin{tabular}{|c|c|}
\hline Conceito & Aplicação no Programa Cultura Viva \\
\hline $\begin{array}{l}\text { Dispositivos técnicos - jurídicos } \\
\text { ou tecnológicos -, documentos, }\end{array}$ & $\begin{array}{l}\text { Editais de prêmios, bolsas e conveniamentos que foram sendo } \\
\text { desenhados e implementados a partir de necessidades práticas e das }\end{array}$ \\
\hline
\end{tabular}

${ }^{24}$ Entrevista VIII [março 2016]. 
cartilhas, procedimentos, etc.

que permitem traduzir

princípios de ação e ações

coordenadas entre atores de

diferentes tipos. experiências da SCDC e do MinC como um todo.

Redes virtuais e presenciais formadas por pontos, pontões, grupos informais, ações transversais, Estado e outros atores da sociedade civil.

Avaliações, visitas, relatórios, sistemas de monitoramento e acompanhamento.

Fonte: Adaptação de quadro elaborado pelo IPEA apud BARBOSA DA SILVA e LABREA (2014: p. 98).

Outros instrumentos são introduzidos a partir da Lei Cultura Viva, como a Plataforma Rede Cultura Viva - que incorpora o Cadastro Nacional dos Pontos de Cultura, e o Termo de Compromisso Cultural (TCC) - que se constitui como uma alternativa ao convênio tradicional, com prestação de contas simplificada. Na visão do MinC (BRASIL, 2015: p. 2), a aprovação do TCC no âmbito de uma lei específica de cultura, com regulamentação feita pelo próprio ministério com a participação dos Pontos, representa o atendimento de "uma demanda histórica de mudança na cultura jurídica do Estado brasileiro".

A introdução desses instrumentos cumpre dois papéis essenciais e complementares. O cadastro - através da plataforma criada - permite a efetivação da autodeclaração pelo autoreconhecimento dos Pontos enquanto sujeitos do fazer cultural. Apesar de não ser uma questão nova para o programa, conforme admitem os próprios gestores da SCDC (ABERTURA, 2016), o auto-reconhecimento fortalece a "identidade discursiva" que os Pontos criaram desde o início do programa. Nesse sentido, pode contribuir para amalgamar a rede de Pontos a partir do reconhecimento dos próprios pares, independente do recebimento de fomento pelo Estado.

O papel do Termo de Compromisso Cultural, por sua vez, é reconhecer as especificidades e fragilidades administrativas dos "fazedores de cultura" enquanto beneficiários de políticas públicas de fomento. Ou seja, o instrumento da política passa a adaptar-se à realidade do setor, e não o contrário - como vinha ocorrendo no caso do convênio.

A complementaridade desse dois instrumentos está na otimização de recursos financeiros, administrativos e humanos. O TCC cobre uma lacuna histórica de adequação administrativa, eliminando entraves burocráticos ao mecanismo de fomento, ao passo em que a Plataforma Rede Cultura Viva apresenta-se como um instrumento dinâmico que dá condições para a autodeclaração, possibilitando incorporar à rede outros atores que a ela se ligam pelo fazer cultural, e não pelo fomento (ibidem). 
Interessante notar, ainda, que o programa Cultura Viva se vale de editais de apoio ao intercâmbio para viabilizar a participação de Pontos em eventos nacionais e internacionais, tanto no âmbito do MinC como do Fundo Ibercultura Viva, cuja coordenação técnica é da SCDC. São instrumentos adicionais, mas que ainda se baseiam na ideia de fomento.

Do ponto de vista da participação social e da representação, além da Comissão Nacional dos Pontos de Cultura (CNdPC) - presente no seu esquema original, o programa desenvolveu uma estrutura de governança baseada em instrumentos de gestão compartilhada da política, com a formação de comitês técnicos ${ }^{25}$, grupos de trabalho (GTs) temáticos ${ }^{26}$ e a participação nos colegiados setoriais que compõem o $\mathrm{CNPC}^{27}$ - Conselho Nacional de Política Cultural (BRASIL, 2010 e 2015; ROLLEMBERG, 2014).

Ademais, tem se intensificado mais recentemente a articulação com movimentos socioculturais, assim como a ativação de circuitos e redes independentes (BRASIL, 2015; BENTES, 2015):

Essa experiência da cultura a partir dos movimentos socioculturais surge como possibilidades de uma renovação radical das políticas públicas. Não é apenas uma mudança da política para a cultura, mas uma mudança da própria cultura política. São muitas iniciativas com potencial para serem instituídas, e o Brasil surge como laboratório desses projetos culturais. Podemos destacar, entre outros, economia e cultura do funk e do hip hop, movimentos que produzem novas identidades e sentimento de pertencimento, de comunidade (rolezinho, bonezaço, midialivristas, ambientalistas, etc.), grupos e redes que criam mundos e atividades produtivas: DJs, donos de equipamentos de som, donos de vans, organizadores de bailes, seguranças e rappers, funkeiros, produtores de conteúdos e mídias, pontos de cultura rurais (violeiros, jongueiros, artesãos), produtores e agentes culturais e das mais diferentes linguagens urbanas e comunitaristas, vindas das artes, mas também dos povos de terreiro, grupos indígenas, de matriz africana, da tradição oral, etc. (BENTES, 2015: p. 2)

\section{Ações complementares}

\footnotetext{
${ }^{25}$ Ex.: Comitê Técnico de Cultura LGBT - Lésbicas, Gays, Bissexuais, Travestis, Transexuais e Transgêneros.

${ }^{26}$ Ex.: GT Indígena, GT Povos e Comunidades de Matriz Africana, GT Acessibilidade Cultural, GT

Teia, GT Cultura Viva.

${ }^{27}$ O CNPC é um órgão colegiado integrante da estrutura do Ministério da Cultura. Tem como finalidade propor a formulação de políticas públicas de cultura, promovendo a articulação e o debate dos diferentes níveis de governo e sociedade civil organizada. Possui 17 Colegiados Setoriais, cada um composto por 15 membros da sociedade civil e 5 do poder público, nas seguintes áreas: Arquitetura e Urbanismo; Arquivos; Arte Digital; Artes Visuais; Artesanato; Circo; Culturas Afro-Brasileiras;

Culturas dos Povos Indígenas; Culturas populares; Dança; Design; Literatura; Livro e Leitura; Moda; Música; Patrimônio Imaterial; Patrimonio Material; e teatro.

Fonte: http://cultura.gov.br/votacultura/sobre-o-cnpc/. Acesso em 22 mar. 2016.
} 
O Ponto de Cultura é a ação prioritária do Programa Cultura Viva. Entretanto, o modelo não é único, existem variações como os Pontos de Leitura, Pontinhos de Cultura ${ }^{28}$, Pontos de Memória e os Pontos de Bens Registrados como Patrimônio Imaterial. Essas categorias foram criadas a partir de 2007 e constituem linhas de fomento específicas, por meio de prêmios e editais próprios. (BRASIL, 2013a)

Além do Ponto de Cultura e dos Pontões, o programa agregou ao longo do tempo outras ações que atuaram de maneira complementar ao fomento direto: Pontos de Rede (integração com estados e municípios); Agente Cultura Viva (protagonismo juvenil); Tuxaua Cultura Viva (rede de articuladores); Escola Viva (integração dos Pontos com as escolas); Bolsa Agente Escola Viva (protagonismo estudantil); Economia Viva (prêmio, rede de economia colaborativa e sustentável); Griôs (educadores da tradição oral); Cultura Digital (software livre e trabalho colaborativo); Ponto de Mídia Livre (prêmio, iniciativas de comunicação livre e compartilhada); Prêmio Cultura Viva (mapeamento cultural); Interações Estéticas (prêmio, residências artísticas em Pontos de Cultura); Circuito Cultura Viva (rodas de conversa e debates); e a Teia da Diversidade (encontro nacional dos Pontos de Cultura); assim como caravanas, circuitos culturais, encontros, eventos colaborativos, fóruns, debates e reuniões com grupos, coletivos e redes de "fazedores de cultura", e editais conjuntos com outras secretarias e entidades vinculadas do Sistema MinC. (CULTURA VIVA, 2005; BRASIL, 2010; 2015)

Não cabe aqui detalhar cada uma dessas ações, mas apenas salientar que se baseiam em sua maioria nos mecanismos de fomento por chamamento público existentes (editais e prêmios, em especial), como iniciativas de regularidade intermitente, a depender dos recursos orçamentários disponíveis. Tais ações estão também conectadas a outras políticas e programas implementados pelo Ministério da Cultura e parceiros externos, como outros órgãos federais.

No período de 2004 a 2014, cerca de 2.500 iniciativas foram contempladas com prêmios em áreas correlatas ao programa Cultura Viva, conforme mostra o quadro abaixo:

\footnotetext{
${ }^{28}$ Pontinhos de Cultura promovem atividades lúdicas, culturais e educacionais voltadas para crianças.
} 
TABELA 6

Prêmios no âmbito do Programa Cultura Viva (Período 2004-2014)

\begin{tabular}{|c|c|c|c|c|}
\hline PRÊMIO & Ano & $\begin{array}{c}\text { Número de } \\
\text { iniciativas } \\
\text { premiadas }\end{array}$ & $\begin{array}{c}\text { Secretaria } \\
\text { Responsável }\end{array}$ & Parcerias \\
\hline 1 - Prêmio ASASI & 2008 & 63 & SPPC & \\
\hline 2 - Prêmio Ludicidade / Pontinhos de Cultura 2008 & 2008 & 200 & SPPC & \\
\hline 3 - Prêmio Interações Estéticas - Residências Artísticas em Pontos & 2008 & 96 & FUNARTE & SPPC \\
\hline 4 - Prêmio Cultura e Saúde 2008 & 2008 & 42 & SPPC & \\
\hline 5 - Prêmio Tuxáua Cultura Viva 2009 & 2009 & 80 & SCC & \\
\hline 6 - Prêmio Pontos de Valor & 2009 & 50 & SCC & \\
\hline 7 - Prêmio Estórias de Pontos de Cultura & 2009 & 25 & SCC & \\
\hline 8 - Prêmio Interações Estéticas - Residências Artísticas em Pontos & 2009 & 71 & SCC, FUNARTE & \\
\hline 9 - Prêmio de Apoio a Pequenos Eventos Culturais & 2009 & 156 & SPPC & \\
\hline 10 - Prêmio Pontos de Mídia Livre & 2009 & 72 & SPPC, SAI & \\
\hline 11 - Prêmio Interações Estéticas - Residências Artísticas em Pontos & 2010 & 137 & FUNARTE, SCC & SCC \\
\hline 12 - Prêmio Cultura Hip Hop 2010 - Edição Preto Ghóez & 2010 & 135 & SID, SCC & Instituto \\
\hline 13 - Prêmio Economia Viva & 2010 & 12 & ScC & \\
\hline 14 - Prêmio Tuxáua Cultura Viva 2010 & 2010 & 45 & SCC & \\
\hline 15 - Prêmio Pontos de Mídia Livre & 2010 & 70 & SCC & \\
\hline 16 - Prêmio Cultura Digital 2010 - Esporos de Pesquisa e & 2010 & 40 & SCC & \\
\hline 17 - Prêmio Pontinhos de Cultura 2010 & 2010 & 300 & SCC & \\
\hline 18 - II Prêmio Cultura e Saúde 2010 & 2010 & 120 & SCC & \\
\hline 19 - 2a Edição do Prêmio ASAS Cultura Viva 2010 & 2010 & 30 & SCC & \\
\hline 20 - Prêmio Agente Jovem de Cultura: Diálogos e Ações & 2011 & 500 & SCC & SNJ, MS, \\
\hline 21 - Prêmio Arte e Cultura Inclusiva 2011 - Edição Albertina Brasil - & 2011 & 30 & SCC & \\
\hline 22 - Prêmio Rede Cultura Viva Afro-Brasileira 2014 & 2014 & 60 & FCP & SCDC \\
\hline 23 - Prêmio Hip Hop 2014 - II Edição & 2014 & 170 & FUNARTE & SCDC \\
\hline Total & & 2.504 & & \\
\hline
\end{tabular}

Elaboração do autor. Fonte: MinC

http://semanaculturaviva.cultura.gov.br/linhadotempo/editais premios.htm

Adicionalmente, foram concedidas 1079 bolsas em ações de intercâmbio e resgate da memória e tradição oral, sendo mais de $80 \%$ no âmbito da Ação Griô:

TABELA 7

Bolsas outorgadas no âmbito do Cultura Viva (Período 2004-2014)

\begin{tabular}{|c|c|c|c|}
\hline PRÊMIO & Ano & $\begin{array}{l}\text { Número de bolsas } \\
\text { concedidas }\end{array}$ & $\begin{array}{l}\text { Secretaria } \\
\text { Responsável }\end{array}$ \\
\hline $\begin{array}{l}1 \text { - Edital Bolsa Interações Estéticas - Residências Artísticas em } \\
\text { Pontos de Cultura } 2012\end{array}$ & 2012 & 50 & FUNARTE, SCDC \\
\hline 2 - Bolsa de Intercâmbio Cultura Ponto a Ponto 2009 & 2009 & 33 & SCC \\
\hline 3 - Bolsas de Intercâmbio Cultura Ponto-a-Ponto & 2008 & 100 & SPPC \\
\hline 4 - Bolsa de Incentivo Griô 2008 & 2008 & 650 & SPPC \\
\hline 5 - Bolsa de Incentivo Griô 2006 & 2006 & 246 & SPPC \\
\hline Total & & 1079 & \\
\hline
\end{tabular}

A partir de 2015, com a entrada em vigor da Lei Cultura Viva e a mudança da equipe dirigente do MinC, o escopo do programa é alargado, com a introdução do mecanismo da 
autodeclaração e o crescente incentivo ao fortalecimento da cultura de rede (BENTES, 2015), e a reaproximação com os movimentos de mídia livre e de cultura urbana das periferias. Neste sentido, apesar da suspensão temporária dos editais de fomento aos Pontos de Cultura para adaptação aos moldes da nova Lei e sua regulamentação, a SCDC lança editais destinados ao público dos Pontos, buscando ainda ativar novos campos de participação e gestão compartilhada (BRASIL, 2015). A tabela abaixo ilustra essas novas ênfases:

TABELA 8

Editais lançados pelo MinC em 2015, com alcance para Pontos/Pontões de Cultura já constituídos ou em potencial:

\begin{tabular}{|c|c|c|c|c|}
\hline Edital/Prêmio & $\begin{array}{l}\text { Iniciativas } \\
\text { premiadas }\end{array}$ & $\begin{array}{c}\text { Prêmio por } \\
\text { iniciativa ( } R \$)\end{array}$ & $\begin{array}{c}\text { Características / Público } \\
\text { Alvo }\end{array}$ & Requisitos \\
\hline \multirow[t]{2}{*}{$\begin{array}{l}\text { Edital } \quad \text { Cultura de } \\
\text { Redes } \\
\text { Local) }\end{array}$} & 20 & $50.000,00$ & $\begin{array}{l}\text { Entidades Culturais (com } \\
\text { CNPJ) }\end{array}$ & $\begin{array}{l}\text { Mínimo } 01 \text { ano de articulação } \\
\text { contínua e } 02 \text { anos de atuação } \\
\text { comprovada na área cultural }\end{array}$ \\
\hline & 20 & $50.000,00$ & $\begin{array}{l}\text { Coletivos Culturais (sem } \\
\text { CNPJ) }\end{array}$ & $\begin{array}{l}\text { Mínimo } 01 \text { ano de articulação } \\
\text { contínua e } 02 \text { anos de atuação } \\
\text { comprovada na área cultural }\end{array}$ \\
\hline \multirow[t]{2}{*}{$\begin{array}{l}\text { Edital Cultura de } \\
\text { Redes (Categoria } \\
\text { Nacional/Regional) }\end{array}$} & 10 & $200.000,00$ & $\begin{array}{l}\text { Projeto de caráter } \\
\text { nacional, articulando } \\
\text { redes com no mínimo } 05 \\
\text { estados da federação }\end{array}$ & $\begin{array}{l}\text { Mínimo de } 01 \text { ano de articulação } \\
\text { regular e contínua prévia ao edital }\end{array}$ \\
\hline & 10 & $100.000,00$ & $\begin{array}{l}\text { Projeto de caráter } \\
\text { regional }\end{array}$ & $\begin{array}{l}\text { Mínimo de } 01 \text { ano de articulaçãoo } \\
\text { regular e contínua prévia ao edital }\end{array}$ \\
\hline $\begin{array}{l}\text { Edital de } \\
\text { Fortalecimento das } \\
\text { Redes Municipais de } \\
\text { Pontos de Cultura }\end{array}$ & $\begin{array}{r}3 \\
15 \\
5 \\
2 \\
1\end{array}$ & $\begin{array}{c}90.000,00 \\
120.000,00 \\
180.000,00 \\
250.000,00 \\
400.000,00\end{array}$ & $\begin{array}{l}\text { Projetos que guardem } \\
\text { consonância com as } \\
\text { diretrizes e critérios do } \\
\text { Plano de Trabalho Anual } \\
\text { do FNC29 }\end{array}$ & $\begin{array}{l}\text { Atender às exigências do FNC } \\
\text { Ter Sistema Municipal de Cultura já } \\
\text { instituído por lei municipal (60 } \\
\text { municípios pré-classificados) }\end{array}$ \\
\hline $\begin{array}{l}\text { Prêmio Pontos de } \\
\text { Cultura Indígenas }\end{array}$ & 70 & $40.000,00$ & $\begin{array}{l}\text { Atividades já realizadas ou } \\
\text { em realização por povos } \\
\text { indígenas }\end{array}$ & Não se aplica \\
\hline \multirow[t]{3}{*}{$\begin{array}{l}\text { Prêmio Pontos de } \\
\text { Mídia Livre }\end{array}$} & 10 & $100.000,00$ & $\begin{array}{l}\text { Entidades culturais (com } \\
\text { CNPJ), com iniciativas já } \\
\text { realizadas ou em } \\
\text { andamento, de alcance } \\
\text { nacional }\end{array}$ & $\begin{array}{l}\text { Alcance das ações em no mínimo } 3 \\
\text { regiões do País, incluindo o local de } \\
\text { origem da entidade }\end{array}$ \\
\hline & 25 & $40.000,00$ & $\begin{array}{l}\text { Coletivos culturais (sem } \\
\text { CNPJ), com iniciativas já } \\
\text { realizadas ou em } \\
\text { andamento, de alcance } \\
\text { estadual }\end{array}$ & $\begin{array}{l}\text { Alcance das ações nos limites do } \\
\text { estado de origem do coletivo }\end{array}$ \\
\hline & 45 & $40.000,00$ & $\begin{array}{l}\text { Coletivos culturais (sem } \\
\text { CNPJ), com iniciativas já } \\
\text { realizadas ou em } \\
\text { andamento, de alcance } \\
\text { local/municipal }\end{array}$ & $\begin{array}{l}\text { Alcance das ações nos limites do } \\
\text { município de origem do coletivo }\end{array}$ \\
\hline
\end{tabular}

Elaboração do autor. Fonte: Ministério da Cultura. ${ }^{30}$

${ }^{29} \mathrm{FNC}$ - Fundo Nacional de Cultura

${ }^{30}$ Editais disponíveis em http://www.cultura.gov.br/1026. Acesso em 20 mar. 2016. 
Ademais, tendo em vista a visibilidade internacional do programa e a formação de uma Rede Latino-Americana de Pontos de Cultura e iniciativas similares, vale citar a participação da SCDC/MinC em instâncias intergovernamentais regionais e globais, como a Comissão da Diversidade Cultural do Mercosul Cultural, o programa Ibercultura Viva e a Convenção da UNESCO sobre a Proteção e Promoção da Diversidade das Expressões Culturais. Nas instâncias internacionais com participação da sociedade civil, destacam-se algumas ações de intercâmbio de experiências e circulação internacional dos Pontos, bem como a participação brasileira nas duas edições do Congresso Latino-americano de Cultura Viva Comunitária, numa ampla articulação fomentada pela SCDC. (BRASIL, 2015)

\section{Outros aspectos relevantes do programa}

Não há como descrever o Cultura Viva, entretanto, sem mencionar os três pilares conceituais do programa: autonomia, protagonismo e empoderamento. São os valores fundantes, a razão de ser do programa.

Parte-se do princípio de que o Ponto de Cultura deve sempre respeitar a dinâmica própria local, concebendo "a autonomia como prática, como processo de modificação das relações de poder e como exercício de liberdade", constituindo a própria realização dos atos de participação e afirmação social (BRASIL, 2010: p. 20). O protagonismo se apresenta na medida em que os Pontos são entendidos como sujeitos de suas práticas (ibidem: p. 21). O empoderamento social nos Pontos é entendido como um processo, instrumento de transformação das relações econômicas e de poder (ibidem: p. 22).

Esses conceitos só podem ser entendidos no programa quando se considera que o contexto de formulação da política cultural brasileira é marcado pela valorização da diversidade cultural e pela compreensão de que a cidadania cultural e o direito à cultura são pressupostos da pluralidade da criação cultural, donde a necessidade de ampliação do direito à cultura (IPEA, 2011).

Em um projeto de construção da cidadania cultural, os agentes mediadores de cultura assumem papel relevante para o desenvolvimento da ação cultural. Estas mediações são realizadas em diferentes níveis e instâncias do espaço público, seja entre o Estado e a sociedade civil, seja no próprio universo da sociedade civil [...]. Há diversos agentes mediadores destas relações e os pontos de cultura representam aí um importante sujeito político, contribuindo para ampliação e garantia da cidadania cultural. (ibidem: p. 51)

Outros valores, como a própria diversidade, o comunitarismo e a colaboração emergem da experiência prática dos Pontos (BRASIL, 2015). Ao mesmo tempo, surgem 
novos desafios de atenção às redes socioculturais emergentes, tanto no campo dos direitos quanto no campo econômico (BENTES, 2015: p. 4):

Estamos falando de um movimento social das culturas que não demanda postos de trabalho ou de uma relação patrão/empregado, como na fábrica fordista e na reivindicação de uma juventude mais conservadora. Precisam, para se constituir como movimento e campo, de acesso a direitos e a benefícios sociais. Precisam acessar os "commons", bens comuns: internet, acesso a repertórios, moradia, sede, acesso ao sistema de saúde e seguridade. (BENTES, 2015: p. 4)

\section{Desafios enfrentados pelo programa}

O programa Cultura Viva encantou o Brasil por suas proposições, entretanto dificuldades administrativas e de gestão levaram à necessidade de deslanchar um processo de redesenho do programa em 2012, em meio a uma crise persistente gerada pela ampliação do número de Pontos e Pontões sem preparo adequado do terreno (BARBOSA DA SILVA e LABREA, 2014). Nesse sentido, foi feito um rigoroso mapeamento de problemas pela equipe do IPEA responsável pela condução do processo junto ao GT Cultura Viva, criado especificamente para discutir o redesenho a partir dos desafios enfrentados pelos Pontos.

Sendo assim, no intuito de não entediar o leitor com uma longa descrição da problemática enfrentada pelos Pontos e pelos gestores do programa, replicarei abaixo um quadro-resumo elaborado pelo IPEA, com a sistematização dos principais problemas do Cultura Viva à época. É certo que, nos três anos que se sucederam, algumas ações já foram tomadas para dirimir questões, inclusive com a aprovação da Lei Cultura Viva e sua regulamentação. Mas tal sistematização nos auxiliará mais à frente, no próximo capítulo, na análise comparativa Brasil-Argentina e na reflexão sobre os instrumentos de gestão e a estrutura de governança do programa.

\section{TABELA 9}

\section{Programa Cultura Viva e seus problemas}

\begin{tabular}{|c|l|}
\hline Componente & \multicolumn{1}{c|}{ Descrição do problema } \\
\hline \multirow{3}{*}{ Marco jurídico } & $-\quad \begin{array}{l}\text { Reflexão sobre a conveniência de institucionalizar o Cultura Viva por meio de uma } \\
\text { lei, na expectativa de torná-lo uma política pública de Estado - estabilizando-o. } \\
\text { Enfrentar o problema dos significados do Projeto de Lei Cultura Viva, que propõe } \\
\text { atualmente o desenho de uma política nacional, e não apenas a institucionalização } \\
\text { do Programa conforme a proposta original. } \\
\text { Relatórios da CGU apontam falhas no processo de gestão e prestação de contas e } \\
\text { gargalo nos fluxos burocráticos. }\end{array}$ \\
\hline Reç̧amentários e & $\begin{array}{l}\text { Atrasos sistemáticos nos repasses de recursos; contingenciamento orçamentário/ } \\
\text { financeiro. }\end{array}$ \\
\hline
\end{tabular}




\begin{tabular}{|c|c|}
\hline Componente & Descrição do problema \\
\hline financeiros & $\begin{array}{l}\text { - } \quad \text { Dificuldade em aprovação de relatório de prestação de contas. } \\
\text { - } \quad \text { Defasagem de registro nos sistemas SICONV e SALICWeb. }\end{array}$ \\
\hline Recursos humanos & $\begin{array}{l}\text { - } \quad \text { Fragilidades quanto à estrutura interna burocrática de fluxo e de pessoal para o } \\
\text { acompanhamento dos editais e convênios. } \\
\text { - Número insuficiente de recursos humanos - funcionário estável - e alta } \\
\text { rotatividade. }\end{array}$ \\
\hline Convênios & $\begin{array}{l}\text { - Inexperiência quanto aos procedimentos burocráticos decorrentes das obrigações } \\
\text { constantes dos editais. } \\
\text { - } \quad \text { Ausência de diagnóstico quanto à real demanda da sociedade por recursos. } \\
\text { - } \quad \text { Ausência de sistema e ciente e contínuo de monitoramento, acompanhamento e } \\
\text { avaliação dos planos de trabalho de convênios diretos e com entes parceiros. } \\
\text { - } \quad \text { Necessidade de vincular as políticas descentralizadas a sistema de monitoramento } \\
\text { do programa. }\end{array}$ \\
\hline Editais de prêmios & $\begin{array}{l}\text { - Instruções precárias quanto aos procedimentos burocráticos decorrentes das } \\
\text { obrigações constantes dos editais. } \\
\text { - } \quad \text { Utilização do prêmio em substituição aos convênios - prêmios híbridos e em parte } \\
\text { restritos aos pontos. }\end{array}$ \\
\hline Editais de bolsas & $\begin{array}{l}\text { - Instrução precária quanto aos procedimentos burocráticos decorrentes das } \\
\text { obrigações constantes dos editais. }\end{array}$ \\
\hline $\begin{array}{l}\text { Sustentabilidade do } \\
\text { Programa Cultura } \\
\text { Viva }\end{array}$ & $\begin{array}{l}\text { - } \quad \text { Estrutura burocrática inadequada e insuficiente para garantir um fluxo operacional } \\
\text { ao Cultura Viva. } \\
\text { - } \\
\text { Estrutura burocrática inadequada, provocando operacionalidade de ciente, } \\
\text { inabilitando organizações da sociedade civil. }\end{array}$ \\
\hline Redes & $\begin{array}{ll}- & \text { Indefinição sobre quem integra as redes. } \\
\text { - } & \text { Quais os papéis de cada ator que as integra. } \\
\text { - } & \text { Definição de plano de comunicação. } \\
\text { - } & \text { Instrumentos de coordenação de atividades. } \\
\text { - } & \text { Necessidade de construir relações de confiança e reconhecimento mútuo entre os } \\
& \text { atores. }\end{array}$ \\
\hline
\end{tabular}

Fonte: IPEA apud BARBOSA DA SILVA e LABREA (2014: p. 106).

\section{Linha do Tempo do programa ${ }^{31}$}

Da mesma forma, com vistas a permitir uma análise mais apurada do programa e a identificação de pontos de inflexão no mesmo, elaborei uma linha do tempo com os principais acontecimentos e marcos jurídico-administrativos que ocorreram no período 2004-2016, direta ou indiretamente relacionados ao Cultura Viva ou aos Pontos de Cultura.

Com a apresentação dessa linha do tempo, encerrarei a descrição geral do programa Cultura Viva, partindo para um sobrevôo ao programa Puntos de Cultura, da Argentina, a ser abordado na seção 2.2 .

\footnotetext{
${ }^{31}$ Elaboração do autor. Fonte dos dados: http://semanaculturaviva.cultura.gov.br/linhadotempo/ . Acesso em 14 jan. 2016.
} 


\section{FIGURA 3}

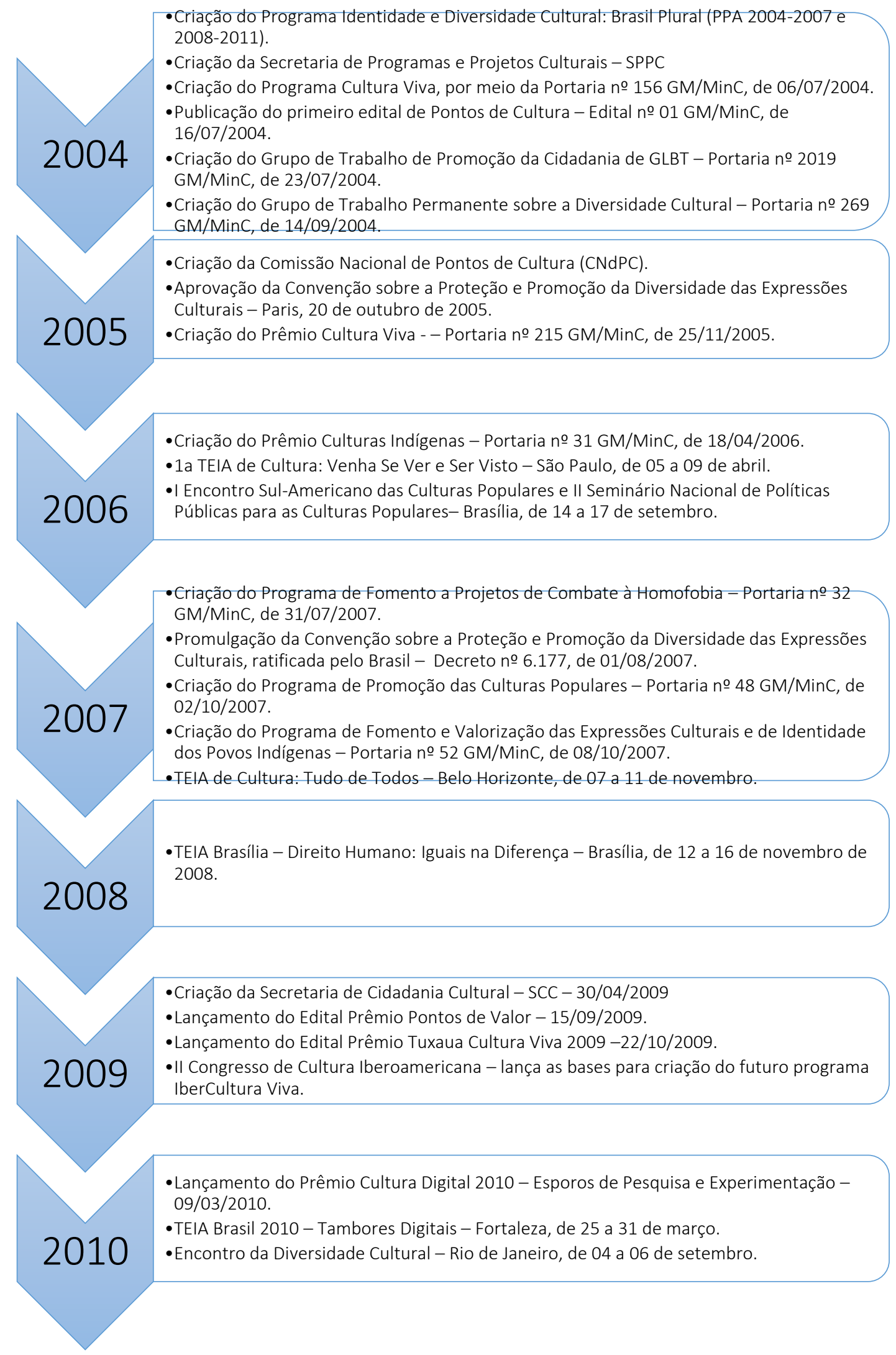




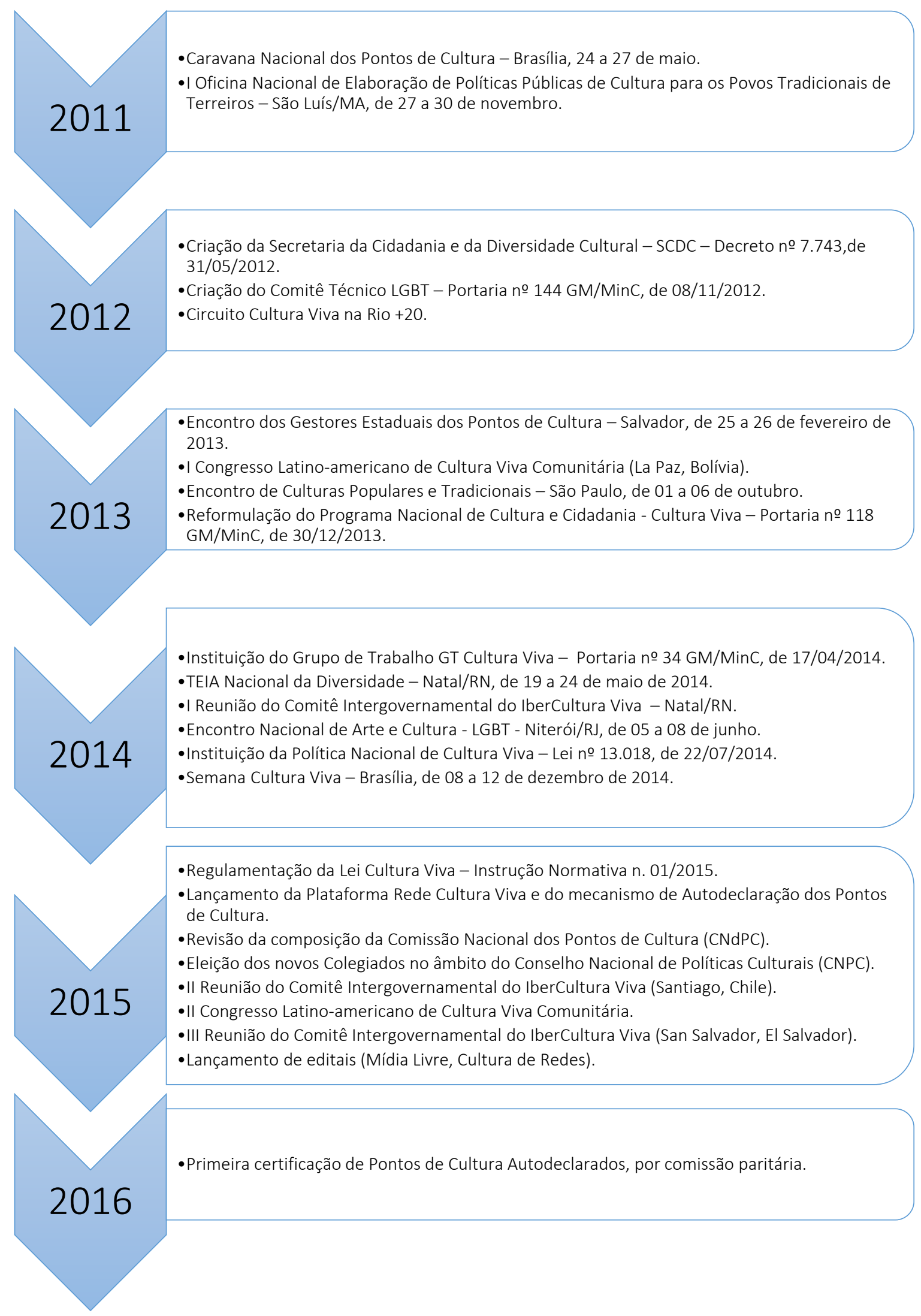




\subsection{O Programa Puntos de Cultura na Argentina: adaptação ou REINVENÇÃO?}

O programa argentino Puntos de Cultura foi instituído em 2011, no âmbito da então Secretaria de Cultura da Nação - que é absorvida na estrutura do novo Ministério da Cultura da Nação Argentina, criado em 2014. Não obstante ter sido inspirado no programa brasileiro Cultura Viva - cuja menção expressa consta nos documentos oficiais e sítio na internet ${ }^{32}$ - o programa argentino possui características próprias e adaptadas ao contexto daquele País. $\mathrm{Na}$ análise que se fará a seguir, serão destacadas suas principais características e peculiaridades de sua implementação, com vistas a subsidiar a posterior análise comparada em relação ao modelo brasileiro.

De modo geral, o programa absorve os principais conceitos e fundamentos do Cultura Viva, especialmente no que se refere aos princípios de autonomia, protagonismo e empoderamento, à noção de gestão compartilhada e à proposta de constituição de uma rede nacional.

El programa consiste en apoyar proyectos socioculturales implementados por distintos grupos de la sociedade civil. Los Puntos de Cultura funcionan a partir de una gestión compartida entre el Estado y la comunidade para la articulación de acciones y proyectos ya existentes en el território, con la intención de dar continuidade y a la vez potenciar las distintas manifestaciones culturales y expresiones populares. Nuestro objetivo principal será formar una red nacional de organizaciones culturales. [...] De hecho, el caminho recorrido en estos últimos años nos ha permitido lanzar durante 2011 el programa a nível nacional tomando la experiência implementada en Brasil como modelo y aprovechando todo el trabajo prévio realizado. (ARGENTINA, 2011: p. 16)

A contextualização do programa no âmbito das políticas culturais nacionais aponta para aspectos inerentes à sua realidade política e social, incorporando as orientações da Presidência argentina no que se refere à intensificação da ação no território, ao fortalecimento da organização popular e à luta contra a pobreza e a exclusão social, bem como à modificação de condições estruturais para o desenvolvimento da sociedade em um novo paradigma de

\footnotetext{
${ }^{32} \mathrm{O}$ sítio Puntos de Cultura na internet (http://puntos.cultura.gob.ar/) contém amplo material de consulta sobre o programa - incluindo publicações para download - além de informações sobre como participar do programa, registro de atividades e divulgação de convocatorias (editais e chamadas públicas). Nota-se uma atenção especial com a publicização das ações do programa, a partir de peças de comunicação impactantes e com uma identidade visual própria.

${ }^{33}$ Foram mantidos nesta citação os grifos do texto original.
} 
trabalho e inclusão social. O programa enquadra-se, portanto, no esforço declarado do governo argentino - a partir de 2003 - com vistas à reversão do processo de exclusão social, com ações que refletem a constituição da chamada "batalha cultural" (ARGENTINA, 2011).

Todos estos cambios, que apuntan a modificar las condiciones estructurales, dan cuenta de la batalla cultural que se está desarrollando y que se seguirá profundizando. Esta batalla cultural implica la transformación de la sociedad: mayores niveles de inclusión y justicia social, fuerte movilización popular y participación democrática y recuperación de la política como herramienta de transformación social y reparación histórica. (ARGENTINA, 2011: p. 13) $)^{34}$

Tais aspectos refletem, ainda, uma ênfase política do programa argentino no reforço da característica contra-hegemônica do programa e, particularmente, da ação cotidiana dos Puntos de Cultura. Isto está refletido não só nos documentos fundantes do programa (ARGENTINA, 2011 e 2012), mas também persiste no relatório da primeira avaliação de impacto do programa (ARGENTINA, 2015).

O programa constitui parte importante do núcleo de políticas socioculturais do Ministério da Cultura argentino, no qual se adota um conceito amplo de cultura:

Desde el Ministerio de Cultura de la Nación, se entiende la cultura en su sentido amplio, es decir, como conjunción de prácticas, valores, cosmovisiones que son parte constitutiva de la propia identidade; como fuerza que da sentido de pertinência como Pueblo, como potencia para la construcción de un futuro compartido, de un horizonte.

El eje principal de las políticas culturales reside, entonces, en la reafirmación de la cultura como espacio primordial de construcción de un modelo de desarrollo democrático, federal e inclusivo. La cultura es fuertemente estructurante en todos los niveles del mundo social, porque toda política económica y de construcción de ciudadanía responde a una matriz cultural. (ARGENTINA, 2015: p. 9)

Cabe destacar que o programa Puntos de Cultura foi precedido por um programa de apoio (subsidios) empreendido desde 2005 no âmbito da Secretaria de Cultura da Nação Argentina, a partir das orientações políticas do governo peronista que assumiu o governo do País em 2003. O apoio consistia no repasse de recursos a fundo perdido para pequenos projetos de organizações sociais ou comunidades indígenas com personalidade jurídica.

Em 2009, com a nomeação do Secretário de Cultura Jorge Coscia, passou-se a delinear uma política geral de subsídios que potencializasse as linhas já existentes, adequando os requisitos e procedimentos à realidade das organizações. Em 2010, ano do Bicentenário da Revolução de Maio, foi criado o "Programa de Subsídios para o Desenvolvimento

\footnotetext{
${ }^{34}$ Foram mantidos nesta citação os grifos do texto original.
} 
Sociocultural", incorporando as chamadas "organizações de base”, historicamente excluídas desse tipo de processo por não possuir personalidade jurídica própria. (ARGENTINA, 2011)

Neste sentido, a transição para o programa Puntos de Cultura, em 2011, incorporou a equipe técnica de base do programa anterior, proporcionando o aproveitamento da curva de aprendizagem dos seis anos de interação com agentes da sociedade civil e comunidades de base (informação verbal) ${ }^{35}$. Essa mesma equipe técnica havia tido contato com a experiência brasileira desde 2009, tanto em visitas ao Brasil quanto por meio de organizações sociais argentinas que demandavam a atenção do governo para a necessidade de aprofundar ações conjuntas nessa área (ARGENTINA, 2011).

\subsubsection{Visão geral do programa}

No seu formato original, o programa Puntos de Cultura contempla o apoio financeiro (subsidios) e técnico - nos campos material e simbólico - com as seguintes modalidades de apoio: fornecimento de equipamento para produção e registro audiovisual; formação, capacitação e assistência técnica em Tecnologias da Informação e Comunicação e estratégias de trabalho cultural comunitário; interconexão entre os Puntos, por meio de encontros nacionais e regionais, além de portal na internet como ferramenta de comunicação e difusão; articulação com diferentes programas da então Secretaria de Cultura da Nacão - SCN. As iniciativas de articulação entre os Puntos e a integração dos mesmos em outros programas da SCN foram reunidas na ação denominada Puente Cultura Nación. Constitui-se, ainda, a Rede Nacional dos Pontos de Cultura, a partir dos encontros nacionais e regionais e o portal na internet. (ARGENTINA, 2011; 2012)

O programa procura cobrir toda a amplitude do País, contemplando 450 Puntos distribuídos em 228 localidades de todas as regiões argentinas: Cidade de Buenos Aires; Província de Buenos Aires; NEA (Nordeste Argentino); NOA (Noroeste Argentino); Centro; Cuyo; e Patagonia. (ARGENTINA, 2015)

Como se pode verificar nos mapas abaixo, a Província e a Cidade de Buenos Aires reúnem conjuntamente cerca de $40 \%$ dos Puntos contemplados. Não obstante, a distribuição nas demais regiões do País é razoavelmente equilibrada, com ligeiro destaque para as regiões Centro e Noroeste, que concentram em torno de $15 \%$ dos Puntos cada. Córdoba é a província

\footnotetext{
${ }^{35}$ Entrevista I [julho 2015].
} 
com o terceiro maior número de Puntos (38), o que corresponde aproximadamente à quantidade presente em cada uma das três regiões minoritárias (NEA, Cuyo e Patagonia).

FIGURA 4

\section{Puntos de Cultura: Distribuição por regiões - Argentina}
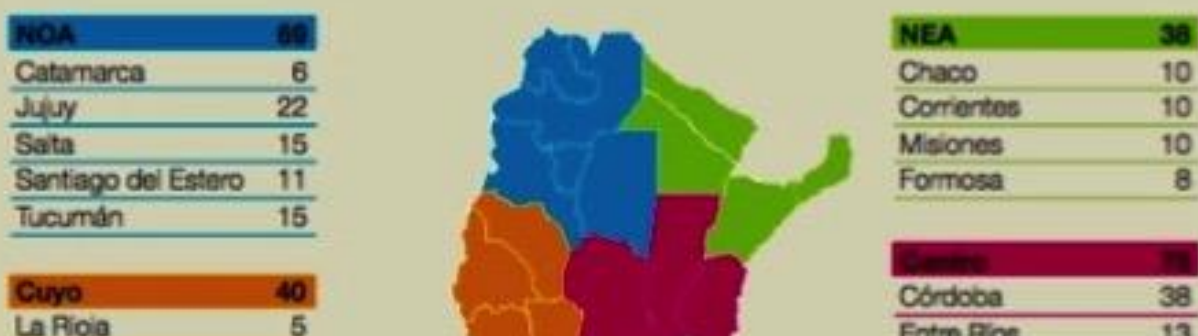

Chaco

Corrionter

Misiones

Formosa

\begin{tabular}{lr}
\hline Cuyo & 40 \\
\hline La Pioja & 5 \\
\hline Mendoza & 13 \\
\hline San Juan & 14 \\
\hline San Lius & 8 \\
\hline
\end{tabular}

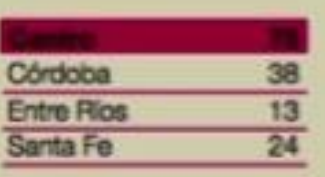

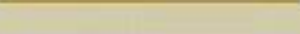

\begin{tabular}{lr}
\hline Patagonia & 37 \\
\hline Chubut & 4 \\
\hline La Pampa & 4 \\
\hline Neugudn & 13 \\
\hline RoNegro & 10 \\
\hline Santa Cruz & 2 \\
\hline Terra de Fucgo & 4 \\
\hline
\end{tabular}
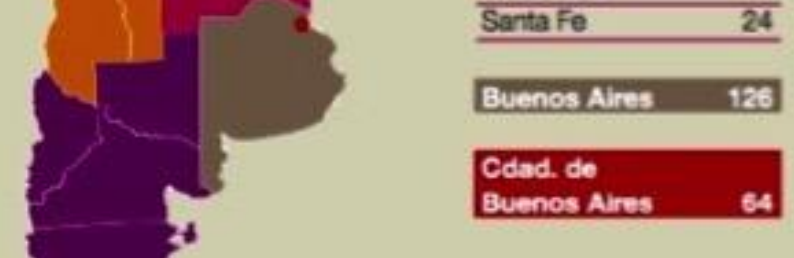

Cdad. de

Buenos Arre:

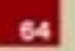

Total de

Puntos

de Cultura

449

Fonte: Ministerio de Cultura, Presidencia de la Nación (ARGENTINA, 2015: p. 11) 
FIGURA 5

Puntos de Cultura: Distribuição Georreferenciada - Argentina

C Cultura Argentina

f $y \cdot$

\section{Mapa de los Puntos de Cultura}

Uniendo fuerzas en todo el pais a travbs de 450 organizaciones sociales

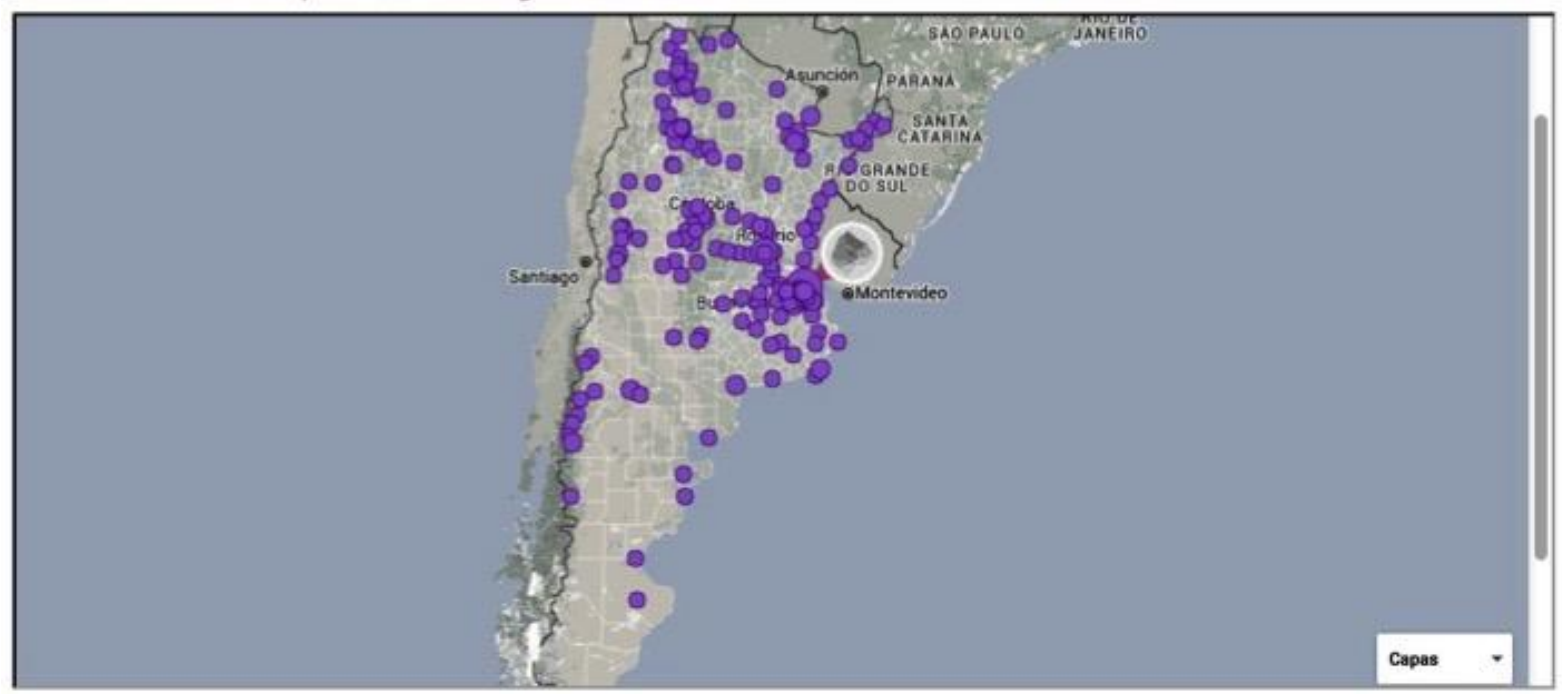

Fonte: SINCA / Ministerio de Cultura, Presidencia de la Nación

http://puntos.cultura.gob.ar/menu/registro-nacional/mapa-sincal Acesso em 19/02/2016

A tabela abaixo ilustra o número de localidades que o programa cobre em cada província:

FIGURA 6

Puntos de Cultura: Número de Localidades atendidas por Província

\begin{tabular}{|c|c|c|c|c|}
\hline \multirow{3}{*}{$\begin{array}{l}\text { Total de } \\
\text { localidades }\end{array}$} & PROVINCIA & _ocalidad & PROVINCIA & Localidad \\
\hline & Buenos Aires & 67 & La Rioja & 2 \\
\hline & Ciudad de Buenos Aires & 15 & Santa $\mathrm{Fe}$ & 13 \\
\hline \multirow{10}{*}{$\begin{array}{l}\text { Los Puntos de Cultura } \\
\text { están distribuidos en } \\
228 \text { localidades del } \\
\text { pals: no solo en } \\
\text { grandes cludades, sino } \\
\text { tamblén en pueblos, } \\
\text { zonas rurales, villas y } \\
\text { asentamientos. Ano a } \\
\text { ano, se incrementa esta } \\
\text { distribución territorial }\end{array}$} & Córdoba & 18 & Tucumán & 7 \\
\hline & Jujuy & 16 & Salta & 10 \\
\hline & Mendoza & 8 & Misiones & 7 \\
\hline & Chaco & 5 & San Juan & 8 \\
\hline & Entre Rios & 7 & Santiago del Estero & 7 \\
\hline & Corrientes & 4 & Neuquén & 8 \\
\hline & Formosa & 4 & Río Negro & 5 \\
\hline & La Pampa & 3 & San Luis & 4 \\
\hline & Catamarca & 3 & Tierra del Fuego & 2 \\
\hline & Chubut & 4 & Santa Cruz & 1 \\
\hline
\end{tabular}

Fonte: Ministerio de Cultura, Presidencia de la Nación (ARGENTINA, 2015: p. 14) 
O programa dispõe de cinco linhas de apoio, implementadas por meio de convocatórias (ou editais) de seleção pública: i) Integral; ii) Específico; iii) Indígena; iv) De Base; v) Círculos de Cultura. Cada uma dessas linhas foi desenhada para abarcar grupos e organizações com diferentes necessidades e potencialidades, contemplando tanto as que têm personalidade jurídica (associações civis, fundações, cooperativas e mutuales ${ }^{36}$ ), quanto as organizações de base sem personalidade jurídica, além das comunidades indígenas inscritas no Registro Nacional de Comunidades Indígenas ${ }^{37}$, sem necessidade de intermediação por uma ONG ou qualquer outro ator social. (ARGENTINA, 2011; 2012; 2015)

Vale ressaltar que exigência ou não de personalidade jurídica própria não pode ser considerada uma questão menor. Grande parte dos programas de apoio na área de cultura, tanto na Argentina quanto no Brasil, esbarram na tradição burocrática desses países de lidar apenas com entidades que possuem personalidade jurídica - o que naturalmente exclui grande parte dos agentes e coletivos culturais.

O programa Puntos de Cultura argentino parece ter encontrado uma solução administrativa viável, incorporando as chamadas "organizações de base". Nas entrevistas realizadas durante a pesquisa de campo em Buenos Aires, este tema foi apontado como um avanço importante do programa, beneficiando consideravelmente a relação entre o Estado e as organizações da sociedade civil. Foram necessárias, entretanto, adaptações administrativas e de normativas internas no âmbito da então Secretaria de Cultura da Nação - hoje Ministério da Cultura - para respaldar a implementação dessa inovação, sem necessidade de alterações substantivas em normativos e regras legais de instâncias superiores ou na esfera constitucional.

No que tange ao perfil de atividades desenvolvidas pelas entidades beneficiárias do programa, consideram-se diferentes modelos de trabalho. As propostas de trabalho dos

\footnotetext{
${ }^{36}$ As Asociaciones Mutuales (associações mutualistas - ou mutuais) são regidas pela Ley de Mutualidades n. 20.321, art. $2^{\circ}$. Funcionam como cooperativas/associações de ajuda mútua, inspiradas na solidariedade, com o objetivo de viabilizar ajuda recíproca frente a riscos eventuais ou de promover o bem estar material e espiritual. Atuam mediante uma contribuição periódica e baseiam-se no mutualismo enquanto doutrina e prática de vida. Para informações mais detalhadas, consultar o sítio da Confederación Argentina de Mutualidades. (http://www.camargentina.org.ar/mutualismo/historia/ Último acesso em 18 fev. 2016.)

${ }^{37} \mathrm{Na}$ Argentina, as comunidades indígenas cadastradas no Registro Nacional de Comunidades Indígenas adquirem personalidade jurídica própria, conforme disposto no Art. 75, inciso 17 da Constituição Nacional. As regras específicas relacionadas a este tema, sob tutela do Instituto Nacional de Asuntos Indígenas - INAI, têm como pressuposto a união indissolúvel entre a identidade étnica dos povos indígenas e os territórios que tradicionalmente ocupam. Para maiores informações sobre este regramento, consultar: https://www.desarrollosocial.gob.ar/wp-content/uploads/2015/08/6.-INAITierras-y-registro-nacional-de-comunidades-ind--genas.pdf. Acesso em 18 fev. 2016.
} 
Puntos são bastante heterogêneas, podendo incluir atividades típicas de centros culturais, oficinas (talleres) itinerantes, atividades de formação, produção de conteúdos e mostras, articulação com outros atores sociais e ações sócio-educativas, bem como difusão e circulação artístico-cultural de expressões populares, entre outras. (ARGENTINA, 2015)

O quadro abaixo classifica as atividades desenvolvidas, conforme distribuição nos Puntos de Cultura contemplados até o momento:

\section{FIGURA 7}

Puntos de Cultura (Argentina): Perfil por atividades/espaços

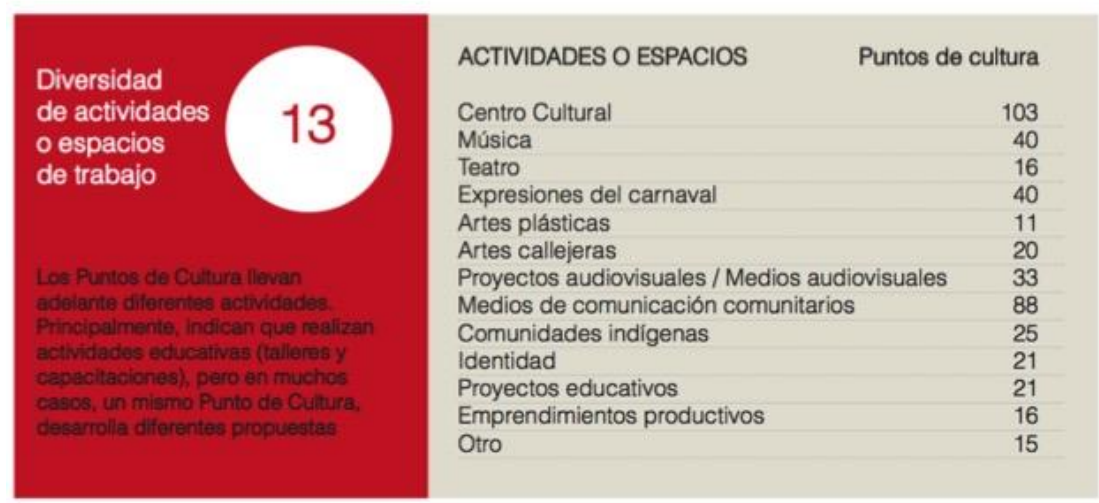

Fonte: Ministerio de Cultura, Presidencia de la Nación (ARGENTINA, 2015: p. 20)

\section{Características gerais das linhas de apoio: ${ }^{38}$}

A linha Integral contempla projetos de fortalecimento geral da área cultural da organização, bem como melhoria da qualidade das produções e ampliação de escala.

A modalidade Específico abrange empreendimentos voltados a facilitar e/ou fomentar o acesso, consumo e produção artística (oficinas, espetáculos, mostras); a desenvolver atividades de formação e capacitação com multiplicadores locais; ou atividades de caráter audiovisual voltadas para sensibilização quanto ao exercício da liberdade de expressão e superação da desigualdade de informação.

A linha Indígena apóia projetos de promoção da diversidade cultural, difusão, valorização e salvaguarda de tradições, costumes, línguas, crenças e formas de organização tradicional de povos indígenas.

\footnotetext{
${ }^{38}$ Fonte: documentos oficiais do programa (ARGENTINA, 2011; 2012; 2015).
} 
Os Puntos de Cultura de Base incluem organizações presentes em territórios de alta vulnerabilidade social, que requerem equipamentos e insumos para possibilitar sua produção autônoma, voltada para as comunidades onde residem e atuam.

Todos os Puntos de Cultura recebem um kit de equipamentos, incluindo computador, câmera de vídeo/fotografia digital e um pendrive, bem como acesso a software livre para edição de áudio e vídeo.

Além das linhas supra-mencionadas, constituiu-se uma linha de apoio única, com apenas um processo seletivo, lançada como parte do Plano Nacional de Igualdade Cultural, destinando recursos para apoiar atividades de grandes centros culturais comunitários, denominados "Círculos de Cultura". Além de serem especializadas em uma ou mais disciplinas, como teatro comunitário, circo social, produção fonográfica ou audiovisual, entre outras, as entidades contempladas nesta modalidade devem dispor de especialistas e professores para capacitação continuada.

\section{Alguns números do programa Puntos de Cultura ${ }^{39}$ :}

$>$ O programa conta com 449 Puntos de Cultura, com a seguinte distribuição: ${ }^{40}$

- Punto de Cultura de Base (40,5\%);

- Punto de Cultura Específico (18,3\%);

- Punto de Cultura Integral (33,2\%);

○ Punto de Cultura Indígena (6,5\%);

- Círculos de Cultura (1,5\%).

$>$ O Registro Nacional do Programa já contabiliza 3500 organizações sociais e comunidades indígenas;

Foram realizados até 2015 os seguintes projetos e atividades:

○ 2200 projetos apoiados;

○ 2 encontros nacionais e 13 encontros regionais realizados;

○ 20 capacitações, 20 jornadas de difusão e 2 publicações;

○ 200 atividades no projeto Puente Cultura Nación (ações: "Café Cultura”, "Chocolate Cultura", mostras de direitos humanos, oficinas de cinema de animação, apresentações artísticas, etc.)

Convocatórias (editais ou chamadas públicas) realizadas até 2015:41

\footnotetext{
${ }^{39}$ Fonte: ARGENTINA (2015: pp. 24-31)

${ }^{40} 100 \%=449$
} 
○ $1^{\text {a }}$ convocatória (2011): 98 Puntos contemplados; total $\$ 4.000 .000$.

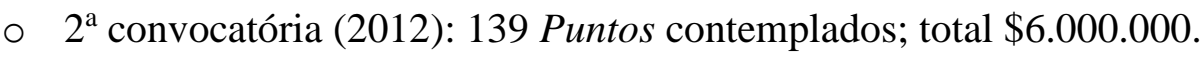

○ Círculos de Cultura (2012): 7 entidades contempladas; total $\$ 2.000 .000^{42}$.

○ $3^{\text {a }}$ convocatória $(2013)^{43}: 205$ Puntos contemplados; total $\$ 8.000 .000$.

O número de candidaturas apresentadas na primeira convocatória foi de 613; a segunda convocatória contou com 687 candidatos, e a terceira contabilizou 915 candidaturas, registrando um aumento de $33 \%$ em relação à anterior e de $49 \%$ em relação à primeira. Dentre as linhas de apoio, o maior destaque foi para o segmento de Base, cujo número de selecionados no terceiro edital foi bastante significativo (87), com número praticamente equivalente à soma dos dois primeiros $(37+59)$, conforme ilustra o quadro abaixo:

FIGURA 8

\section{Quadro-resumo: Convocatórias Puntos de Cultura}

\begin{tabular}{lrlllllll} 
Lineas & Cantidad & 1ra. Convocatoria & \multicolumn{2}{ll}{ 2da. Convocatoria } & \multicolumn{2}{l}{ 3era. Convocatoria } \\
Base & 182 & Presentados & 613 & Presentados & 687 & Presentados & 915 \\
Especifico & 82 & Seleccionados & 98 & Seleccionados & 139 & Seleccionados & 205 \\
Integral & 149 & Base & 37 & Base & 59 & Base & 87 \\
Indigena & 29 & Especifico & 23 & Especifico & 25 & Especifico & 37 \\
Círculos & 7 & Integral & 31 & Integral & 47 & Integral & 67 \\
TOTAL & 449 & Indigena & 7 & Indigena & 8 & Indigena & 14 \\
& & & & & & &
\end{tabular}

Fonte: Ministerio de Cultura, Presidencia de la Nación (ARGENTINA, 2015: p. 31)

\footnotetext{
${ }^{41}$ Os valores monetários estão descritos em Pesos Argentinos (\$), sendo 50\% do valor em apoio financeiro e $50 \%$ em apoio para compra de equipamentos e realização de encontros e atividades de capacitação.

42 Apoio financeiro e formação de cooperativas

${ }^{43}$ Segundo informações obtidas nas entrevistas de campo realizadas em junho de 2015, em Buenos Aires, a última convocatória foi realizada em 2013, devido a questões orçamentárias envolvendo a criação do novo Ministério da Cultura em 2014 e peculiaridades do ano fiscal argentino vis à vis a reforma ministerial. Não foi possível levantar dados, a posteriori, sobre a retomada de investimentos no programa no cenário pós-eleições presidenciais de outubro/novembro de 2015.
} 
2.3.2. Sobre o funcionamento e a lógica de operação do programa ${ }^{44}$ :

\section{Requisitos}

Os requisitos para participação no programa Puntos de Cultura são relativamente simples, exigindo-se basicamente a inscrição no Registro Nacional de Puntos de Cultura e o fornecimento de fotocópias simples de documentos no ato de apresentação de propostas. As entidades inscritas no Registro Nacional ficam então habilitadas a apresentar projetos para concorrer aos subsídios oferecidos por meio de convocatórias públicas, procedimento equivalente aos editais e chamadas públicas feitos no Brasil. Somente as organizações selecionadas nos processos seletivos são chamadas a apresentar cópias autenticadas dos documentos apresentados no ato de inscrição, bem como outros que se fizerem necessários a depender do edital.

TABELA 10

QUADRO-RESUMO: LINHAS DE APOIO DO PROGRAMA PUNTOS DE CULTURA (ARGENTINA)*

\begin{tabular}{|c|c|c|c|c|c|}
\hline $\begin{array}{l}\text { Linhas } \\
\text { de Apoio: }\end{array}$ & $\begin{array}{l}\text { Personalidade } \\
\text { Jurídica }\end{array}$ & Espaço Físico & $\begin{array}{l}\text { Experiência } \\
\text { prévia no } \\
\text { território }\end{array}$ & $\begin{array}{l}\text { Duração } \\
\text { do apoio }\end{array}$ & $\begin{array}{c}\text { Apoio financeiro recebido } \\
\text { (em Pesos Arg. \$) }\end{array}$ \\
\hline Integral & Sim & $\begin{array}{l}\text { Sim } \\
\text { (próprio, alugado, } \\
\text { ou comodato) }\end{array}$ & $\begin{array}{c}\text { Acima de } 2 \\
\text { anos }\end{array}$ & $\begin{array}{c}1 \text { ano } \\
\text { (renovável } \\
\text { por mais } 2 \\
\text { anos) }\end{array}$ & $\begin{array}{l}\$ 40.000\left(1^{\circ} \text { e } 2^{\circ} \text { convênios) }\right. \\
\$ 45.000\left(3^{\circ} \text { convenio) }\right.\end{array}$ \\
\hline Específico & Sim & Não requer & Não requer & 6 meses & $\begin{array}{l}\$ 20.000\left(1^{\circ} \text { e } 2^{\circ} \text { convênios) }\right. \\
\$ 25.000 \text { (3 convenio) }\end{array}$ \\
\hline Indígena & Sim & Não requer & Não requer & 1 ano & $\begin{array}{l}\$ 20.000\left(1^{\circ} \text { e } 2^{\circ} \text { convênios) }\right. \\
\$ 25.000 \text { (3 convenio) }\end{array}$ \\
\hline De Base & Não é requisito & Não requer & $\begin{array}{l}\text { Acima de } 2 \\
\text { anos de } \\
\text { trabalho no } \\
\text { território, com } \\
\text { aval de pelo } \\
\text { menos } 2 \\
\text { instituições }\end{array}$ & 1 ano & $\begin{array}{l}\$ 5.000\left(1^{\circ} \text { convenio }\right) \\
\$ 7.000\left(2^{\circ} \text { convenio }\right) \\
\$ 10.000\left(3^{\circ} \text { convenio }\right)\end{array}$ \\
\hline $\begin{array}{l}\text { "Círculos de } \\
\text { Cultura" } \\
\text { (linha única, } \\
\text { destinada a } \\
\text { grandes centros } \\
\text { culturais) }\end{array}$ & Sim & $\begin{array}{c}\text { Sim } \\
\text { (próprio, } \\
\text { comodato ou } \\
\text { usufruto por mais } \\
\text { de } 10 \text { anos), com } \\
\text { salão de mais de } \\
100 \mathrm{~m} 2\end{array}$ & $\begin{array}{l}\text { Mínimo de } 5 \\
\text { anos }\end{array}$ & $\begin{array}{l}\text { Eventual } \\
\text { (prêmio } \\
\text { único) }\end{array}$ & $\begin{array}{l}\$ 300.000 \text { para cada um dos } \\
7 \text { projetos selecionados* } \\
\text { (* deste valor, um mínimo } \\
\text { de } \$ 90.000 \text { para apoio a } \\
\text { cooperativas culturais) }\end{array}$ \\
\hline
\end{tabular}

${ }^{44} \mathrm{~A}$ informações sobre o funcionamento do programa aqui expostas foram sistematizadas a partir dos dados constantes nos documentos oficiais explicativos sobre programa (ARGENTINA, 2011; 2012; 2015), bem como no Portal do programa na internet (http://puntos.cultura.gob.ar/) 


\section{Difusão e publicização das convocatórias (editais)}

As convocatórias são divulgadas pelo Ministério da Cultura da Nação e os órgãos máximos órgãos de cultura provinciais, utilizando-se dos meios de comunicação nacionais e provinciais, além do contato direto com diversas organizações sociais, entidades e agentes do meio cultural que formam o público-alvo deste programa e de outras ações de base territorial implementadas em nível nacional. Adicionalmente, o Ministério da Cultura utiliza-se de parcerias com universidades nacionais de todo o País para divulgação do programa, bem como organiza jornadas de divulgação e de assessoramento.

\section{Critérios de elegibilidade}

O programa possui critérios de elegibilidade bem definidos para orientar os processos de seleção por meio de convocatórias. Longe de constituir uma barreira para a entrada de novos postulantes à obtenção de apoio do Estado, a observação desse conjunto de critérios pelo órgão ofertante tende a contribuir para uma seleção que seja, ao mesmo tempo, transparente e eficaz, prezando pela boa utilização dos recursos públicos.

São considerados, primeiramente, os objetivos e o alcance da atividade projetada no marco da política cultural nacional, bem como seu impacto sociocultural em termos de fomento da participação popular, revitalização da identidade local e geração de inclusão.

Outro fator elencado é a consistência e viabilidade (factibilidad) do projeto, considerando ainda o nível de resposta a demandas culturais existentes nas comunidades. Ênfase especial é dada para projetos em pequenas localidades e/ou zonas de alta vulnerabilidade social e/ou que tratem de temas relevantes para a comunidade, assim como propostas provenientes de entidades que ainda não receberam apoio do governo ou que tenham pouco histórico de apoio.

Quanto à qualidade e viabilidade do projeto, levam-se em conta os seguintes critérios: criatividade da proposta; adequação e congruência interna; e estrutura organizativa e administrativa adequada.

Outro critério importante adotado pelo Ministério da Cultura na seleção final dos projetos é garantir uma distribuição regional equilibrada dos Puntos de Cultura no território argentino. Além disso, analisa-se a amplitude de cobertura e impacto do projeto, em especial no que se refere à quantidade de destinatários (dimensão ou escala do público-alvo), à possibilidade de melhoria na qualidade das produções e à localização geográfica e territorial 
pertinente. Enfatiza-se também a busca por projetos capazes de promover mudanças culturais significativas e/ou melhoria nas capacidades da organização (fortalecimento institucional), bem como o fomento à participação de jovens.

\section{Instrumentos de apoio ao processo de seleção}

Como instrumentos de apoio ao processo de seleção, destacam-se a existência de cartilha de instruções para formulação de projetos, que é disponibilizada no Portal Puntos de Cultura na internet. Cabe sublinhar que um conjunto bem sistematizado de informações sobre o programa e suas regras de participação está disponível no referido Portal, em formato bastante acessível e de fácil manuseio. ${ }^{45}$

Outros instrumentos identificados são o Registro Nacional de Puntos de Cultura, as próprias convocatórias de projetos - enquanto modelo de seleção pública - e um serviço de assessoramento técnico e administrativo, prestado pela equipe técnica do programa.

Uma característica importante do Registro Nacional é que ele vai formando um cadastro de organizações que fazem atividades culturais no País, independentemente da seleção ou não em uma determinada convocatória. O registro já conta com mais de 3.500 organizações cadastradas (ARGENTINA, 2015). De maneira análoga ao Cadastro Nacional dos Pontos de Cultura - instituído apenas em 2014 no Brasil, pela Lei Cultura Viva - o registro argentino funciona como repositório unificado de informações.

Cabe sublinhar, entretanto, que o registro argentino é comparativamente mais antigo do que o brasileiro, pois estabelecido já no início da implementação do programa, em 2011. Isso permite um melhor mapeamento das experiências em curso no território, bem como sinaliza, no ponto de partida, a intenção de buscar alternativas de atendimento das demandas dessas organizações. Ou seja, o registro organiza informações que poderão ser utilizadas futuramente, para expansão do programa e/ou redimensionamento de políticas governamentais voltadas para esse público, reconhecendo que há muito mais experiências culturais em prática do que o montante que o Estado pode atender com as linhas de fomento de que dispõe.

No que se refere ao instrumento de seleção de projetos a serem apoiados, o programa argentino também utiliza o recurso do chamamento público, por meio de convocatórias similares aos editais e prêmios aplicados no caso brasileiro.

\footnotetext{
${ }^{45}$ Ver: http://puntos.cultura.gob.ar/menu/el-programa/como-participar/ . Acesso em 19 fev. 2016.
} 
Quanto aos instrumentos de parceria ou de fomento às organizações selecionadas, não figura na Argentina ferramenta tão complexa quanto o convênio aos moldes brasileiros. $\mathrm{O}$ procedimento argentino é simplificado, com poucas etapas de validação de informações e mecanismos mais simples de prestação de contas. Nas entrevistas com gestores do programa, foi possível constatar que há sim problemas administrativos e burocráticos, mas estes não são significativos ao ponto de gerar uma celeuma generalizada como no caso brasileiro.

Parte disso se deve à menor rigidez da legislação argentina quanto às parcerias com organizações sem fins lucrativos, mas outra parte também é fruto do aprendizado prévio que houve nas iniciativas que precederam o programa Puntos de Cultura (informação verbal) ${ }^{46}$.

Outro aspecto importante é a solução de parceria encontrada para lidar com as organizações que não têm personalidade jurídica, em especial os Puntos de Cultura de Base. Para esse caso, o Ministério da Cultura utilizou-se de mecanismo de cooperação internacional, firmando convênio com a $\mathrm{OEI}^{47}$, por meio da qual faz os repasses de recursos e fornecimento de equipamentos para os Puntos. Além de eliminar etapas burocráticas, essa parceria permite maior alcance das ações de intercâmbio na rede de puntos de cultura, inclusive a nível internacional.

\section{Etapas do Programa}

De forma resumida, o programa possui três etapas principais:

1. Seleção (exigida apenas cópia simples de documentos);

2. Apresentação de documentação autenticada - etapa esta que conta com assessoria e acompanhamento do Ministério da Cultura;

3. Acompanhamento e visitas técnicas pelos responsáveis regionais da equipe técnica do programa no Ministério da Cultura.

\footnotetext{
${ }^{46}$ Entrevista I [julho 2015].

${ }^{47} \mathrm{OEI}$ - Organização dos Estados Ibero-Americanos para a Educação, a Ciência e a Cultura
} 


\section{Instrumentos associados}

A gestão do programa conta com a participação de responsáveis regionais, membros da equipe do Ministério que acompanham o trabalho dos Puntos e servem de ponto de apoio para esclarecimento de dúvidas e articulação com outras políticas do ministério. O monitoramento contínuo é uma premissa do programa, donde cada responsável monitora os Puntos de uma região específica.

A avaliação realizada identificou, entretanto, alguns relatos sobre dificuldades de manter esse contato contínuo entre Puntos e Ministério (ARGENTINA, 2015), em especial pela distância dos que se encontram em regiões mais longínquas, fora da capital argentina. Some-se a isso as dificuldades encontradas por alguns Puntos de se conectar à rede dos Puntos e de efetivamente realizar um trabalho em rede (ibidem).

Neste aspecto, especificamente em relação ao uso das ferramentas digitais de comunicação em rede, pude observar na breve visita in loco a dois Puntos em Buenos Aires que isso ainda é um ponto para melhoria no programa. $\mathrm{O}$ trabalho em rede me pareceu restringido ao circuito próprio da atuação prévia de cada organização, sem uma conexão direta com a rede maior de Puntos por intermédio do programa.

Uma iniciativa formulada pelo Ministério da Cultura para conectar esses pontos da rede é a realização de encontros regionais e outras atividades integradoras, como as jornadas de difusão e eventos de capacitação. Desde a criação do programa até o ano 2015, foram realizados 13 encontros regionais, 20 jornadas de difusão e 20 atividades de capacitação, além de 2 encontros nacionais de Puntos de Cultura. (ARGENTINA, 2015: p. 29).

Outras ferramentas relevantes do programa são

- Assistência técnica e artística

- Apadrinhamento ("Padrinazgos"e "Madrinazgos") por artistas e personalidades do meio cultural

- Atividades do programa "Puente Cultura Nación"

○ "Café Cultura" (palestras/"charlas")

○ "Chocolate Cultura" (espetáculos infantis)

○ Programa de Direitos Humanos ("Pancartas")

- Oficinas de cinema de animação em comunidades indígenas 
Cabe ressaltar, como aspecto de maior organicidade do modelo argentino, a estruturação do programa em cinco linhas de apoio principais (Integral; Específico; Indígena; De Base; e "Círculos de Cultura". As linhas são apresentadas de forma clara e bem delineada, o que se constitui importante fator de transparência do programa - com critérios previamente estabelecidos e divulgados amplamente.

Além disso, note-se que as linhas de apoio são dimensionadas para um suporte de curto e médio prazo às organizações, trabalhando com um horizonte de tempo que vai de seis meses a dois anos ${ }^{48}$.

Sobre o impacto gerado pelo programa Puntos de Cultura na Argentina, até o presente momento, sistematizamos abaixo os dados presentes no primeiro relatório de impacto do programa (ARGENTINA, 2015), encomendado pelo Ministério da Cultura e realizado com o apoio de 13 universidades nacionais da Argentina, sendo pelo menos uma universidade por região. Foram visitados e entrevistados 34 Puntos de Cultura, nos últimos meses de 2013 e durante o ano de 2014.

TABELA 11

Análise de impacto do Programa Puntos de Cultura na Argentina ${ }^{49}$

\begin{tabular}{|l|l|}
\hline $\begin{array}{l}\text { CATEGORIZAÇÃO DO } \\
\text { IMPACTO }\end{array}$ & \multicolumn{1}{c|}{ IMPACTO OBSERVADO } \\
\hline Impacto simbólico & $\begin{array}{l}\text { Aumento de prestígio social e visibilidade; } \\
\text { Fortalecimento da autoestima do grupo; } \\
\text { Legitimação de práticas culturais locais pelo Estado nacional; } \\
\text { Sentido de pertencimento que gera orgulho/dignidade; } \\
\text { Desafio transformador ao sentir-se apoiado pelo Estado nacional; } \\
\text { Visibilização do trabalho territorial a partir do interesse gerado nos } \\
\text { meios de comunicação; } \\
\text { Visibilidade política das reinvindicações culturais dos Pontos. }\end{array}$ \\
\hline
\end{tabular}

${ }^{48}$ Vide quadro-resumo apresentado mais acima, na sub-seção "Requisitos", com a duração do suporte concedido em cada linha de apoio.

${ }^{49}$ A sistematização e análise detalhada de impacto do programa encontra-se em documento do Ministério da Cultura da Nação Argentina, intitulado "Puntos de Cultura - Una política transformadora: Relevamiento y análisis del impacto territorial"(ARGENTINA, 2015: pp. 41-55), que contem os resultados da primeira análise de impacto da implementação do programa Puntos de Cultura na Argentina, em âmbito nacional.

${ }^{50}$ Os itens de categorização do impacto desta coluna seguem a nomenclatura e os termos utilizados pelo Ministério de Cultura da Nação Argentina em sua sistematização (ibidem). 


\begin{tabular}{|c|c|}
\hline $\begin{array}{c}\text { CATEGORIZAÇÃO DO } \\
\text { IMPACTO } 50\end{array}$ & IMPACTO OBSERVADO \\
\hline $\begin{array}{l}\text { Fortalecimento das } \\
\text { organizações: } \\
\text { interna e em seus } \\
\text { territórios }\end{array}$ & $\begin{array}{l}\text { Melhoria na organização interna (divisão de funções, planejamento, } \\
\text { adesão de novos integrantes, etc.); } \\
\text { Melhoria da ação no território (capacidade de articular esforços e } \\
\text { recursos em novas parcerias, inserção no bairro }{ }^{51} \text {, etc.); } \\
\text { Fortalecimento institucional (equipes qualificadas, ampliação de } \\
\text { participantes, integração outros atores sociais); } \\
\text { Vínculos reforçados entre os membros e com a comunidade; } \\
\text { Valorização da própria identidade (patrimônio, costumes, tradições); } \\
\text { Adesão de participantes de bairros/povoados mais tradicionais; } \\
\text { Crescimento quantitativo e qualitativo da participação da população } \\
\text { dos bairros nas atividades dos Pontos (mais estabilidade e } \\
\text { compromisso na participação); } \\
\text { Fortalecimento do vínculo que a organização e seus membros } \\
\text { estabelecem com seu entorno (bairro) e com outras organizações e } \\
\text { atores sociais; } \\
\text { Restabelecimento de vínculos na população (ex.: comunidades } \\
\text { historicamente divididas). }\end{array}$ \\
\hline $\begin{array}{l}\text { Equipamento } \\
\text { técnico e apoio } \\
\text { econômico- } \\
\text { financeiro }\end{array}$ & $\begin{array}{l}\text { Maior grau de reconhecimento social, a partir da melhoria da } \\
\text { qualidade das produções com novos equipamentos; } \\
\text { Maior legitimidade dos projetos, a partir da chancela material e } \\
\text { econômica do Estado; } \\
\text { Crescimento das produções digitais utilizando novas tecnologias; } \\
\text { Ampliação das propostas e projetos, repercutindo na inclusão dos } \\
\text { Pontos em encontros e festivais. }\end{array}$ \\
\hline $\begin{array}{l}\text { Inclusão digital e } \\
\text { portal web }\end{array}$ & $\begin{array}{l}\text { Possibilidade de intercâmbio de conteúdos e informação por meio do } \\
\text { Portal do programa na internet; } \\
\text { Aumento da quantidade de produções digitais; }\end{array}$ \\
\hline
\end{tabular}

\footnotetext{
${ }^{51}$ A noção de bairro aqui empregada remete ao termo "barrio" (em castelhano). Em muitos países latino-americanos o termo barrio é associado a populações menos favorecidas, como as favelas brasileiras, as comunas colombianas, ou o que na Argentina se conhece como villa ou villa miseria. $\mathrm{O}$ programa Puntos de Cultura argentino tem como uma de suas prioridades alcançar as organizações provenientes de bairros menos favorecidos e de maior vunerabilidade social, mas não exclusivamente oriundos das villas. Vale ressaltar, entretanto, que na Argentina o sentimento de pertencimento a um barrio é bastante acentuado do ponto de vista cultural. O barrio é tido como espaço de tradições e práticas arraigadas, muitas vezes de resistência cultural. Neste sentido, os vizinhos de um barrio sentem-se orgulhosos de pertencer àquela determinada comunidade, sem deixar de reconhecer-se como parte dela, mesmo quando se deslocam para outros lugares. Ver definição de barrio no seguinte link: http://definicion.de/barrio/. Acesso em 11 fev. 2016.
} 


\begin{tabular}{|l|l|}
\hline $\begin{array}{l}\text { CATEGORIZAÇÃO DO } \\
\text { IMPACTO } 50\end{array}$ & IMPACTO OBSERVADO \\
\hline Trabalho em rede ${ }^{52}$ & $\begin{array}{l}\text { O impacto é diverso, com níveis variados de efetiva conexão, } \\
\text { comunicação e trabalho conjunto com outros Pontos; } \\
\text { Vários Pontos acham importante o trabalho em rede, mas dispositivos tecnológicos; } \\
\text { reconhecem que ainda é uma tarefa pendente; } \\
\text { Intercâmbio é visto como grande benefício do trabalho em rede; } \\
\text { Diferentes experiências de articulação executadas (ex. encontros de } \\
\text { formação, montagens de obras de teatro, intercâmbios artísticos, } \\
\text { produções audiovisuais conjuntas, etc.); } \\
\text { Fortalecimento de redes pré-existentes. }\end{array}$ \\
\hline $\begin{array}{l}\text { Cultura que } \\
\text { transforma a } \\
\text { sociedade, o bairro, } \\
\text { as pessoas }\end{array}$ & $\begin{array}{l}\text { Mudanças nas relações entre os Pontos e seu bairro de origem; } \\
\text { Mudanças no plano subjetivo e interpessoal; } \\
\text { Cultura percebida como fundamental para aproximar as pessoas; } \\
\text { Olhar menos estigmatizado sobre os jovens que participam das } \\
\text { oficinas oferecidas pelos Pontos, em relação às atividades da } \\
\text { organização antes de tornar-se Ponto de Cultura; } \\
\text { Acesso das populações de bairros populares, favelas e assentamentos } \\
\text { rurais a atividades culturais associadas aos Pontos (oficinas ou } \\
\text { espetáculos, etc.); } \\
\text { Primeiro acesso de algumas populações a espetáculos culturais, por } \\
\text { meio de atividades complementares dos Pontos de Cultura (ex. } \\
\text { projeto Chocolate Cultura, circo, etc.) }\end{array}$ \\
\hline
\end{tabular}

Elaboração do autor. Fonte: relatório de avaliação de impacto do Ministério da Cultura da Nação Argentina (ARGENTINA, 2015: pp. 41-55).

TABELA 12

\begin{tabular}{|l|l|}
\hline $\begin{array}{c}\text { CATEGORIZAÇÃO DO } \\
\text { IMPACTO }\end{array}$ & \multicolumn{1}{c|}{ ASPECTOS NEGATIVOS } \\
\hline $\begin{array}{l}\text { Inclusão digital e } \\
\text { portal web }\end{array}$ & $\begin{array}{l}\text { Dificuldades na utilização dos equipamentos, devido à grande } \\
\text { heterogeneidade no que diz respeito ao acesso, capacitação, }\end{array}$ \\
\hline
\end{tabular}

\footnotetext{
${ }^{52}$ Ações empreendidas a partir da coordenação do programa: estímulo a redes sociais, realização de oficinas (talleres) em encontros regionais e nacionais, estímulo a projetos de articulação entre organizações.
} 


\begin{tabular}{|l|l|}
\hline $\begin{array}{c}\text { CATEGORIZAÇÃO DO } \\
\text { IMPACTO }\end{array}$ & \multicolumn{1}{c|}{\begin{tabular}{c}
\multicolumn{1}{c|}{ ASPECTOS NEGATIVOS } \\
disposição e prioridades dos diversos Pontos; \\
Impossibilidade de uso do Portal web por alguns Pontos, por falta de \\
expertise e/ou não-priorização; \\
Comunicação boca-a-boca continua sendo mais importante do que a \\
digital para alguns Pontos; \\
Inclusão digital tem impactos desiguais sobre cada população, em \\
alguns casos não sendo considerada como ferramenta central para \\
intercâmbio ou difusão.
\end{tabular}} \\
\hline Trabalho em rede 53 & $\begin{array}{l}\text { Dificuldades de alguns Puntos de gerar um efetivo trabalho em rede; } \\
\text { Distância entre os Puntos e dos Puntos em relação aos responsáveis } \\
\text { regionais do programa dificulta trabalho em rede, na visão de alguns } \\
\text { Puntos. }\end{array}$ \\
\hline
\end{tabular}

Elaboração do autor. Fonte: relatório de avaliação de impacto do Ministério da Cultura da Nação Argentina (ARGENTINA, 2015: pp. 41-55).

\footnotetext{
${ }^{53}$ Ações empreendidas a partir da coordenação do programa: estímulo a redes sociais, realização de oficinas (talleres) em encontros regionais e nacionais, estímulo a projetos de articulação entre organizações.
} 


\subsection{QUADRO COMPARATIVO BRASIL-ARGENTINA: UMA ABORDAGEM PRELIMINAR}

O quadro abaixo resume as principais características de funcionamento dos programas brasileiro e argentino, em perspectiva comparada.

TABELA 13

\begin{tabular}{|c|c|}
\hline ARGENTINA & BRASIL \\
\hline \multicolumn{2}{|c|}{ Requisitos para ser Ponto de Cultura } \\
\hline $\begin{array}{l}\text { Inscrição no Registro Nacional de Puntos de Cultura } \\
\text { Fotocópias simples de documentos no ato de } \\
\text { apresentação de propostas } \\
\text { Inscrição das propostas para seleção }\end{array}$ & $\begin{array}{l}\text { Pessoa jurídica de direito privado sem fins lucrativos } \\
\text { ou coletivo cultural sem constituição jurídica } \\
\text { Mínimo } 1 \text { (um) ano de existência em atividades } \\
\text { culturais } \\
\text { Cartas de reconhecimento de no mínimo } 2 \text { (dois) } \\
\text { Pontos de Cultura, instituições públicas, privadas, } \\
\text { coletivos culturais ou comunidades relacionados à } \\
\text { arte, cultura, educação ou desenvolvimento } \\
\text { comunitário. }\end{array}$ \\
\hline \multicolumn{2}{|c|}{ Difusão e Convocatórias/Editais } \\
\hline $\begin{array}{l}\text { Meios de comunicaçao nacionais e provinciais } \\
\text { Divulgacao pelos máximos órgaos de cultura } \\
\text { provinciais } \\
\text { Contato direto com organizações sociais } \\
\text { Divulgação pelas univesidades nacionais de todo o } \\
\text { País } \\
\text { Jornadas de divulgaçao e assessoramento (Ministério } \\
\text { da Cultura da Nação) }\end{array}$ & $\begin{array}{l}\text { Editais abertos (nacionais) } \\
\text { Editais municipais } \\
\text { Plataforma de Autodeclaração (implantada em 2015) } \\
\text { Oficinas regionais e estaduais } \\
\text { Plantões de dúvidas } \\
\text { Atendimentos diversos }\end{array}$ \\
\hline \multicolumn{2}{|c|}{ Instrumentos de apoio ao Processo de Seleção } \\
\hline $\begin{array}{l}\text { Cartilha/instruções para formulação de projetos } \\
\text { disponibilizada na internet } \\
\text { Registro Nacional de Puntos de Cultura } \\
\text { Convocatórias de projetos } \\
\text { Assessoramento técnico e administrativo }\end{array}$ & $\begin{array}{l}\text { "Editais/convênios nacionais e estaduais } \\
\text { Editais/prêmios nacionais } \\
\text { Editais/convênios temáticos voltados para redes } \\
\text { estaduais e municipais (associados ao Sistema } \\
\text { Nacional de Cultura) } \\
\text { Editais de boas práticas de gestão em municípios } \\
\text { Termo de Compromisso Cultural } \\
\text { Plataforma de Autodeclaração (registro)" }\end{array}$ \\
\hline \multicolumn{2}{|c|}{ Etapas do Programa } \\
\hline $\begin{array}{l}\text { 1) Seleção (exigida apenas cópia simples de } \\
\text { documentos) } \\
\text { 2) Apresentação de documentação autenticada (esta } \\
\text { etapa conta com assessoria e acompanhamento do } \\
\text { MinC/AR } \\
\text { 3) Acompanhamento e visitas técnicas (pelos }\end{array}$ & $\begin{array}{l}\text { "Seleção por Editais } \\
\text { Registro de propostas (editais/prêmios) } \\
\text { Registro por Autodeclaração (plataforma própria - a } \\
\text { partir de 2015) } \\
\text { Aprovação e divulgação das propostas } \\
\text { Conveniamento (edital) ou outorga de prêmio }\end{array}$ \\
\hline
\end{tabular}




\begin{tabular}{|c|c|}
\hline ARGENTINA & BRASIL \\
\hline $\begin{array}{l}\text { responsáveis regionais da equipe técnica do } \\
\text { programa no MinC/AR) }\end{array}$ & $\begin{array}{l}\text { Visitas técnicas de acompanhamento de convênios } \\
\text { Reuniões "'in loco"" } \\
\text { Prestação de contas }\end{array}$ \\
\hline \multicolumn{2}{|c|}{ Instrumentos associados } \\
\hline $\begin{array}{l}\text { Responsáveis Regionais } \\
\text { (acompanhamento/monitoramento contínuo) } \\
\text { Encontros regionais } \\
\text { Assistência técnica e artística } \\
\text { Apadrinhamento ("Padrinazgos"e "Madrinazgos") por } \\
\text { artistas e personalidades do meio cultural }\end{array}$ & $\begin{array}{l}\text { "Lei Cultura Viva } \\
\text { Plataforma Rede Cultura Viva (+ Cadastro Lei Cultura } \\
\text { Viva) } \\
\text { Termo de Compromisso Cultural } \\
\text { Comissão Nacional dos Pontos de Cultura (CNPdC) } \\
\text { Apoio técnico na prestação de contas } \\
\text { Editais de intercâmbio (participação em eventos) } \\
\text { Fundo Ibercultura Viva } \\
\text { Grupos de Trabalho (GTs) temáticos } \\
\text { Instrumentos de Gestão Compartilhada: } \\
\text { - Comitê Técnico LGBT } \\
\text { - Comissão Nacional dos Pontos de Cultura } \\
\text { - GT Indígena (MinC) } \\
\text { - Colegiado Indígena } \\
\text { - Colegiados Setoriais (Cultura Popular, Teatro, } \\
\text { Dança, Música, etc.) } \\
\text { - GT Povos e Comunidades de Matriz Africana } \\
\text { - Circuitos e redes independentes } \\
\text { - Articulação com movimentos culturais/sociais " }\end{array}$ \\
\hline \multicolumn{2}{|c|}{ Ações complementares } \\
\hline $\begin{array}{l}\text { "Puente Cultura" } \\
\text { "Café Cultura" (palestras/"charlas") } \\
\text { "Chocolate Cultura" (espetáculos infantis) } \\
\text { Programa de Direitos Humanos ("Pancartas") } \\
\text { Oficinas de cinema de animação em comunidades } \\
\text { indígenas }\end{array}$ & $\begin{array}{l}\text { "Parcerias com órgãos federais } \\
\text { Parcerias e ações integradas com órgãos do Sistema } \\
\text { MinC } \\
\text { Circuito Cultura Viva (2015) } \\
\text { Colegiados e GTs temáticos e/ou setoriais } \\
\text { Fóruns, encontros, reuniões e debates com grupos, } \\
\text { coletivos e redes de "'fazedores de cultura"" } \\
\text { TEIA da Diversidade } \\
\text { Eventos colaborativos (ex. EMERGÊNCIAS) } \\
\text { Intercâmbio de experiências e circulação } \\
\text { internacional } \\
\text { Atuação internacional no âmbito da Convenção da } \\
\text { Diversidade UNESCO } \\
\text { Programa Ibercultura Viva } \\
\text { Programa Cultura de Redes (previsto para 2016)" }\end{array}$ \\
\hline
\end{tabular}




\begin{tabular}{|l|l|}
\hline \multicolumn{1}{|c|}{ ARGENTINA } & \multicolumn{1}{|c|}{ BRASIL } \\
\hline & \\
\hline Outros aspectos relevantes \\
\hline Linhas de apoio:1) Integral2) Específico3) Indígena4) & $\begin{array}{l}\text { "Valores: - autonomia, protagonismo e } \\
\text { empoderamento- diversidade, comunitarismo, } \\
\text { colaboração- atenção às redes emergentesEconomia } \\
\text { viva } \\
\text { Emergência de movimento social da cultura } \\
\text { Cultura de redes } \\
\text { Desafios 2015/2016:- reconectar os "'nós partidos"'" } \\
\text { da rede- desburocratizar a relação com o Estado- } \\
\text { fortalecer a participação- ampliar a incidência e a } \\
\text { cogestão- Financiar/potencializar a diversidade e o } \\
\text { acesso" }\end{array}$ \\
\hline
\end{tabular}




\section{A AÇÃO PÚBLICA CULTURAL: UMA ANÁliSE dA IMPLEMENTAÇÃo dOS PROGRAMAS CULTURA ViVA (BR) E PUNTOS DE CULTURA (AR)}

Este capítulo apresenta uma análise comparada da implementação dos programas Cultura Viva (Brasil) e Puntos de Cultura (Argentina), com enfoque na estruturação da ação pública no domínio da cultura e da cidadania. Neste ponto, o intuito é analisar as trajetórias dessas políticas nos dois países, com ênfase no estudo da adequação ou não das estruturas de governança, dos mecanismos institucionais e dos instrumentos de gestão aos novos desafios da relação entre Estado e sociedade civil. Antes, porém, apresentarei os referenciais teóricometodológicos utilizados e uma proposta de modelo de análise, para que seja possível realizar a análise comparada.

\subsection{AS POLÍTICAS PÚBLICAS NA PRÁTICA: ATORES, ARRANJOS INSTITUCIONAIS E INSTRUMENTOS DE GESTÃO}

\subsubsection{Arranjos institucionais e capacidades estatais}

A partir da discussão mais ampla - apresentada no capítulo 1 - sobre a relação intrínseca entre cultura, desenvolvimento, direitos culturais, cidadania e participação, o presente capítulo apresenta uma análise comparada dos programas Cultura Viva (Br) e Puntos de Cultura (Ar) - descritos no capítulo 2 - com base nos aspectos mais relevantes de sua implementação. Considerando o âmbito das políticas culturais e o conceito amplo de cultura utilizado no Brasil e na Argentina, interessa agora investigar como as políticas públicas são conformadas nos dois países em torno desse conceito e de suas várias dimensões. O interesse aqui é perceber, na política pública, como o Estado interage - na prática - com a sociedade civil para atender suas demandas, interação essa carregada de forças e influências que atuam em várias direções.

O debate em questão suscita questionamentos e reflexão sobre os papéis dos diferentes atores públicos e privados para superação dos desafios de implementação de políticas públicas para o desenvolvimento. Nesta pesquisa, partimos da premissa de que esses atores organizamse de acordo com regras, mecanismos e processos - arranjos institucionais ou estruturas de 
governança - que estabelecem entre si nas transações econômicas ou nas relações políticas e sociais (GOMIDE; PIRES, 2014 e 2014a; FIANI, 2014).

Essa premissa é analisada no livro "Capacidades estatais e democracia: arranjos institucionais de políticas públicas”, de Gomide e Pires (2014), que contém reflexões teóricoconceituais sobre desenvolvimentismo e democracia, além de diversos estudos de caso sobre políticas de desenvolvimento no Brasil, sob a abordagem de arranjos institucionais. Conforme apontado por Gomide e Pires (2014a), apesar do extenso debate sobre a retomada (ou não) de políticas de caráter desenvolvimentista no Brasil, especialmente a partir dos anos 2000, pouco ainda se tem discutido a respeito das capacidades do Estado de executar essas políticas sob um contexto democrático. Tais capacidades seriam respostas aos grandes desafios de conciliar políticas desenvolvimentistas com: a proteção de direitos e interesses de minorias; a participação de diversos atores (políticos, econômicos, sociais) nos processos decisórios e no controle das políticas; e a conciliação das distintas dimensões do desenvolvimento, respeitando múltiplos interesses dos atores e sem violar liberdades, em um contexto pluralista e democrático.

Nesse sentido, no projeto desta pesquisa, lancei o argumento de que a concepção e implementação de políticas culturais de caráter sistêmico e estruturante no Brasil, especialmente a partir de 2003, bem como a proposição de um conjunto de novos marcos legais, estariam contribuindo para a conformação de um novo arranjo institucional na área da cultura. Esse novo arranjo resultaria em novas capacidades para atender às demandas da sociedade e promover o desenvolvimento, a partir de políticas culturais de caráter abrangente e inclusivo. Sendo assim, o estudo comparado Brasil-Argentina serviria como laboratório para identificar quais as características e modelos de arranjo institucional seriam mais relevantes para construção dessas capacidades.

Como um dos suporte metodológicos, utilizei como referência o modelo analítico proposto por Gomide e Pires (2014a), conforme o esquema representado a seguir: 


\section{Modelo analítico adotado}

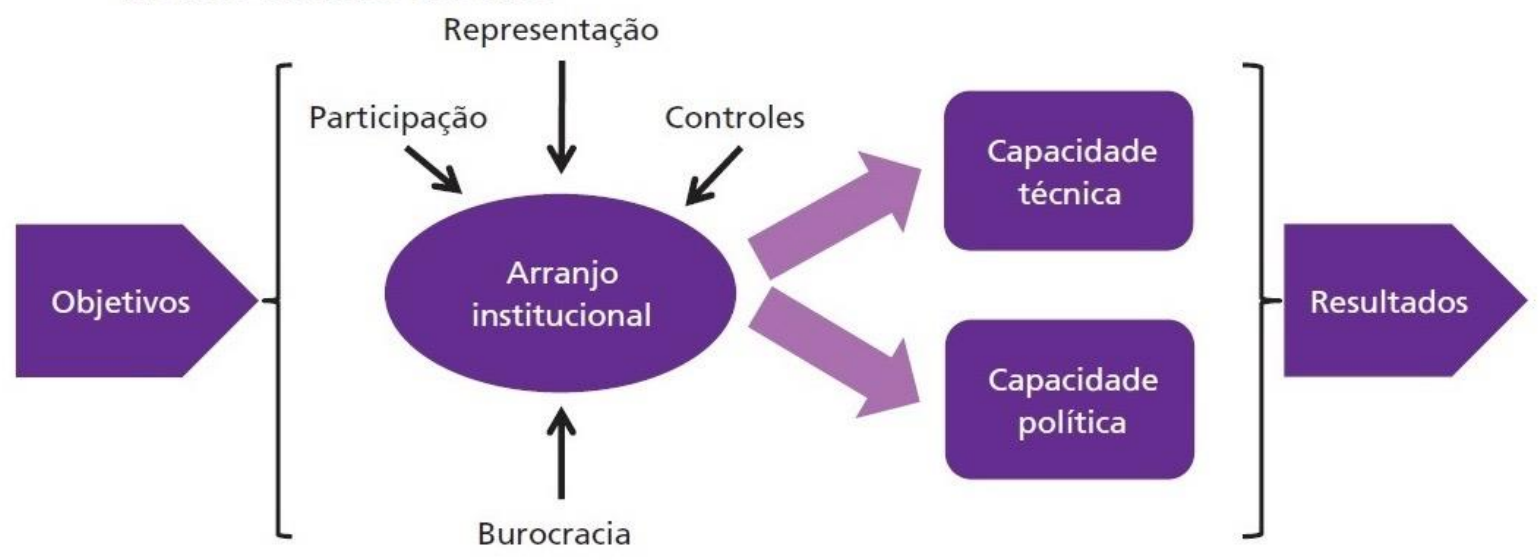

Fonte: GOMIDE e PIRES (2014a, p. 21)

Considerando a interação necessária entre as burocracias do Poder Executivo e os atores dos sistemas representativo, participativo e de controles, o modelo analítico proposto pelos autores busca representar a relação de causalidade entre essa interação e a construção de capacidades técnico-administrativas e políticas, como determinantes dos resultados da política pública. Vale destacar, ainda, a ênfase do modelo na combinação de democracia com outros requisitos da ação estatal (GOMIDE; PIRES, 2014), conforme corroborado por HERRLEIN JR. (2014: p. 97):

A possibilidade de o Estado fornecer serviços coletivos sociais de qualidade depende tanto de sua capacidade técnica quanto do aprofundamento da democracia (Evans e Heller, 2013). Por esta via, o Estado pode lograr um enraizamento social favorável a um programa de metas de desenvolvimento humano. A pressão política democrática contribui para estabelecer sistemas efetivos para o fornecimento de serviços públicos e seu controle local.

Tendo em conta os aspectos acima elencados, na análise comparada desta pesquisa pretende-se identificar em que medida os elementos constitutivos das políticas culturais [brasileira e argentina], os respectivos arranjos institucionais e os instrumentos de gestão utilizados [nos programas analisados] contribuem para - ou refletem - a construção de capacidades estatais para o desenvolvimento.

Dadas as diferentes nuâncias terminológicas possíveis, adotarei um conceito operacional abrangente de arranjo institucional, conforme utilizado por Gomide e Pires:

[...] para efeitos deste livro, o conceito de arranjo institucional é entendido como o conjunto de regras, mecanismos e processos que definem a forma particular como se coordenam atores e interesses na implementação de uma política pública específica. São os arranjos que dotam o Estado de capacidade de execução de seus objetivos. Ou, em outras palavras, são os 
arranjos que determinam a capacidade do Estado de implementar políticas públicas. (GOMIDE; PIRES, 2014a, p. 19-20)

Essa abordagem ampla de arranjos institucionais, entretanto, não nos obriga a adotar um conceito excessivamente amplo de instituições. Conforme ressalta ACCO (2009: pp. 140), pode ser tão "abstrato" quanto "inócuo" adotar um conceito muito genérico, onde tudo pode ser instituição. Parece-me útil, portanto, resgatar um conceito um pouco mais restrito, definindo instituições como "o conjunto, formal ou informal, de procedimentos, normas, rotinas e convenções inscritas na estrutura organizacional de uma comunidade política ou de uma economia política" (HALL e TAYLOR, 2002 apud ACCO, 2009: p. 155).

No que se refere às capacidades estatais, não irei incorrer aqui em uma análise aprofundada dos diversos aspectos que circundam esse conceito abrangente - objeto de tratamento teórico e empírico por vários autores, conforme aponta SOUZA (2016: p. 51). Sendo assim, utilizarei um conceito simplificado de capacidade estatal, que conforme SOUZA (ibidem) constitui-se como "o conjunto de instrumentos e instituições de que dispõe o Estado para estabelecer objetivos, transformá-los em políticas e implementá-las”.

Em seus estudos sobre Estado e desenvolvimento, Peter EVANS (2005, 2008 apud GOMES, 2016) destaca que o contexto de democracia e fortalecimento da sociedade civil deve ser levado em conta quando se fala de capacidades estatais para o desenvolvimento. De acordo com essa abordagem, além da capacidade burocrática (baseada na meritocracia e coordenação de estruturas organizacionais) e de uma relação saudável com o mercado, o Estado deve prezar pela participação democrática de baixo para cima e por uma interlocução de mão dupla com a sociedade civil, contando com "instituições políticas e capacidade de definir objetivos coletivos" (ibidem: pp. 106-107).

Segundo apontam ainda Gomide e Pires (2014a), embora a capacidade técnicoadministrativa para a consecução de políticas de desenvolvimento possa existir na ausência de democracia, o caso brasileiro mostra que é necessário combinar democracia com outros requisitos da ação estatal:

No entanto, no caso brasileiro atual, a consolidação da democracia tem imposto à ação estatal requisitos voltados à inclusão e a relação com os atores afetados na tomada de decisão, na promoção da accountability e no controle de resultados. Isto demanda novas capacidades do Estado, além das necessidades de uma burocracia profissional, coesa e meritocrática. Ou seja, no contexto de um ambiente institucional caracterizado pela existência de instituições representativas, participativas e de controle (social, burocrático e judicial), são necessárias também capacidades políticas para a inclusão de múltiplos atores, o processamento dos conflitos decorrentes e a formação de 
coalizões políticas de suporte para os objetivos e as estratégias a serem adotadas. (ibidem, pp. 20-21)

Verificou-se no capítulo 2 que os discursos dos Ministérios da Cultura do Brasil e da Argentina, especialmente na última década, defendem a necessidade do reconhecimento da política cultural como política estratégica de Estado que contribui para o desenvolvimento do países, tendo a sociedade civil e os setores culturais como protagonistas. Além disso, ambos os discursos enfatizam que o Estado passa a ter um papel importante na democratização do acesso aos meios de produção cultural e a uma cidadania plena, combinando elementos de protagonismo e empoderamento social com o fortalecimento do Estado em seu papel garantidor de direitos culturais.

Essa visão sobre o papel do Estado nas políticas culturais guarda relação intrínseca com o que pontua HERRLEIN JR. (2014, p. 89):

O Estado deve ser concebido não apenas em conexão com a ordem social de classe mas também como expressão da comunidade nacional organizada, sendo seu instrumento de ação coletiva por excelência. Presume-se a possibilidade de alargar a democracia por meio das lutas populares e, assim, abrir caminho para transformar o Estado, enquanto a sociedade se transforma, por meio de inovações institucionais. O exercício exitoso deste papel do Estado parece possível somente por meio de sua articulação com amplas camadas da sociedade civil, em uma democracia. [...] A democracia é o método de organização pelo qual a sociedade confere continuamente o sentido do desenvolvimento, os seus fins últimos. É a forma de processar os conflitos sociais, para que se expressem, institucionalmente, de modo construtivo, como fator dinamizador da sociedade.

Tal perspectiva lança novos desafios para o desenvolvimento das capacidades estatais nas suas três dimensões - técnico-administrativa, político-relacional e jurídica - conforme classificação elencada por Gomide et al. (2014). A primeira deriva do conceito weberiano de burocracia, enfatizando as competências dos agentes do Estado para implementar políticas de forma coordenada e efetiva, dispondo de recursos humanos financeiros e tecnológicos adequados. A segunda dimensão refere-se às habilidades de interlocução e negociação da burocracia do Executivo com os diversos atores, processando conflitos, mediando interesses, interagindo com os agentes do sistema político-representativo e com os canais de participação social (conselhos, conferências, ouvidorias, consultas públicas, etc.). A terceira dimensão jurídica - refere-se à capacidade dos governos e sua burocracia de criarem condições de legalidade para sua atuação - vis à vis o trabalho dos órgãos jurídicos e de controle e agentes do setor privado e da sociedade civil especializados na submissão de pleitos e ajuizamento de ações junto à administração. 
Segundo Gomide et al. (ibidem), o conceito de capacidades estatais remete-se, de maneira mais ampla, a duas dimensões ou gerações de análise, uma mais abrangente referente à criação e manutenção da ordem em um território, e outra focada nos atributos que os Estados possuem (ou não) para atingir os objetivos de suas políticas. Os autores optam por associar o referido conceito "às habilidades ou às competências do Poder Executivo para definir sua agenda e realizar seus objetivos de modo legítimo; em outras palavras, formular e executar políticas públicas em contexto democrático" (ibidem, p. 237).

HERRLEIN JR. (op. cit.), por sua vez, ressalta que algumas funções desenvolvimentistas do Estado precisam ser reconcebidas. O autor elenca as funções clássicas de coordenação, de provisão de uma visão de futuro, de administração de conflitos, e acrescenta a proposição de uma função desenvolvimentista de nivelamento cultural $e$ informacional, visto que "a informação é a base da democracia e a cultura é a base da escolha autêntica" (ibidem, p. 94). Neste sentido, Herrlein Jr. defende que as políticas públicas devem promover formas alternativas de comunicação e organização que permitam adotar métodos descentralizados e de amplo alcance para geração e consumo de informação, aumentando o grau de transparência na sociedade, fator vital para o que ele chama de Estado Democrático Desenvolvimentista - EDD.

\subsubsection{Instrumentos de gestão e a Sociologia da Ação Pública}

Outro referencial teórico-metodológico utilizado nesta pesquisa é a abordagem dos instrumentos de gestão. A literatura nessa área destaca que os instrumentos de gestão não são neutros, produzem efeitos específicos de acordo com sua própria lógica (LASCOUMES; LE GALÈS, 2007) e estruturam comportamentos e condutas (MOISDON, 2006).

Segundo MOISDON (ibidem), não é possível isolar instrumentos de regras e arranjos organizacionais. Para o autor, os instrumentos são apenas parte de uma organização, ao lado de práticas discursivas e informais de mobilização e orientação dos indivíduos, que incluem confiança, conhecimento, persuasão, julgamento pelos pares e autorregulação de grupos. Ele complementa que uma tecnologia de gestão é prescritiva, orienta condutas, define sistemas de valores ligados a competências, determina mecanismos de coordenaçãoo entre os atores, ou até mesmo "cria" (define) novos atores e papéis.

A partir dos textos de Michel Foucault, os estudos de J. C. Moisdon e Armand Hatchuel, na década de 1970, concluíram que os instrumentos de gestão remetem a 
dispositivos de conhecimento/poder (savoir/pouvoir), pois provêm da vontade de agir sobre as liberdades e de controlá-las. Ao se utilizarem de dispositivos de conhecimento (saber) prédeterminados, os instrumentos de gestão representam a síntese do binômio poder/conhecimento; ao mesmo tempo provocam a dispersão do poder e exploram sua capilaridade, multiplicando as relações de poder, verticalmente e horizontalmente. (MOISDON, op. cit.).

Analisando as organizações a partir dos conceitos de "governo" e de "poder pastoral" de Foucault - o poder de conduzir uma coletividade, e não de bloquear ou frear -, o autor defende que as organizações são espaços privilegiados de dispositivos e incentivos positivos, criadores de ação, que garantem a sua própria sobrevivência. As organizações representam, para ele, uma justaposição de regras jurídicas, disciplina e poder pastoral. Os instrumentos de gestão situam-se, portanto, na zona do movimento, da mudança, onde a condução se dá pela ação coletiva.

$\mathrm{Na}$ mesma esteira, a abordagem teórica da Sociologia da Ação Pública (LASCOUMES; LE GALÈS, 2012) defende que a ação pública é um sistema de ordem negociada, onde "são as iniciativas da sociedade civil que movimentam os políticos autistas e as administrações esclerosadas" (ibidem, p. 211). Na visão desses autores, uma sociologia política da ação é uma forma de refletir sobre as novas configurações entre Estado e sociedade civil, sendo que as interações entre os jogos de poder dos atores e das instituições impactam e, de certa forma, orientam a ação pública.

A utilização desse referencial permite uma reflexão mais aprofundada sobre os instrumentos de gestão na relação com as políticas públicas e seus efeitos sobre a implementação das políticas culturais. Como bem salientam LASCOUMES; LE GALÈS (2012: p. 200):

Um instrumento de ação pública constitui um dispositivo simultaneamente técnico e social que organiza relações sociais específicas entre o poder público e seus destinatários em função de representações e de significações de que ele é portador.

A instrumentalização da ação pública remete ao conjunto de problemas apresentados pela escolha e o uso de instrumentos (técnicas, formas de operar, dispositivos) que permitem materializar e operacionalizar a ação governamental. Trata-se de compreender, não apenas as razões que levam a escolher um instrumento em detrimento de outro, mas também verificar os efeitos produzidos por essas escolhas (LASCOUMES; LE GALÈS, 2004) ${ }^{54}$

${ }^{54}$ LASCOUMES P., LE GALÉS P. (Dir.) Gouverner par les instruments, Paris: Presses de SciencesPo, 2004. 
Ademais, segundo destacam LÚCIO et al (2014), para Lascoumes e Le Galès (2004) ${ }^{55}$ os instrumentos ainda podem ser diferenciados em três categorias - instrumento, técnica e ferramenta:

O instrumento é um tipo de instituição social, a técnica é um dispositivo concreto de operacionalização do instrumento e a ferramenta é um microdispositivo no interior da técnica. Embora esta distinção à primeira vista pareça bastante hierárquica e "dura", ela torna-se importante em gestão, pois o instrumento é o portador de significados, os quais são transpostos para as técnicas e ferramentas, garantindo a coerência entre a realização da ação e a visão de mundo, políticas e finalidades norteadoras da ação. $O$ desalinhamento entre os significados e finalidades constituintes do instrumento, suas técnicas e ferramentas impede a realização plena das políticas, uma vez que gera uma contradição interna que acaba por descaracterizar o instrumento e, portanto, o espaço da ação pública. (LÚCIO et al, 2014: p. 154)

Fazendo um exercício de aplicação dessa categorização ao caso concreto dos programas Cultura Viva (Br) e Puntos de Cultura (Ar), aqui abordados, poderíamos considerar, por exemplo, o instrumento do chamamento público como categoria mais ampla; o edital ou convocatória como técnica de viabilização da seleção por chamamento público; e o convênio, o prêmio ou o termo de compromisso cultural como ferramentas de aplicação desse instrumento. Note-se que, no fundo, a concretização das parcerias é o fim último da utilização desses instrumentos. $\mathrm{O}$ instrumento do chamamento público representa um princípio, uma diretriz, um valor que norteia a política pública, ou seja, através desse instrumento reafirma-se a ideia de que todos devem ter a possibilidade de acesso à política, com critérios claros e transparentes. Isso pressupõe a isonomia como um valor básico, onde o interesse público tem primazia sobre o interesse privado de pessoas ou grupos com privilégios específicos.

Para colocar em prática esse princípio, é preciso adotar alguma técnica, usar algo que traduza esses valores - donde se encaixa a figura do edital público ou convocatória aberta, em que são explicitadas as regras de participação, os critérios de seleção, o montante dos recursos aplicados, etc. E após selecionadas as organizações ou as pessoas que serão beneficiárias do programa, cabe ao Estado utilizar uma ferramenta que permita viabilizar o repasse de recursos, prezando pela transparência e accountability dos processos e resultados.

Apesar de considerar que esse raciocínio nos ajuda a compreender melhor o papel e os limites de cada instrumento, técnica ou ferramenta utilizada, os termos "instrumento" e “instrumento de gestão" serão utilizados doravante neste trabalho na sua concepção genérica, podendo referir-se a qualquer uma das três categorias supramencionadas. Farei diferenciações

55 ibidem 
apenas quando isso for útil para melhor esclarecer o ponto em questão. A abordagem dos instrumentos não será utilizada aqui como um fim em si mesma, mas como um meio para permitir a análise dos programas em perspectiva comparada. Interessa-me olhar para o conjunto de instrumentos utilizados e verificar como impactam cada programa e se [e como] são impactados pela interação com os diversos atores e instituições em ação.

Nesse sentido, vale destacar outra delimitação conceitual possível - utilizada no processo de redesenho do programa Cultura Viva ${ }^{56}$-, que é a definição instrumentos de políticas públicas utilizada pelo IPEA ${ }^{57}$ : “dispositivos técnicos - jurídicos ou tecnológicos que permitem traduzir princípios em ações concretas coordenadas entre poder público e atores de diferentes tipos" (BARBOSA DA SILVA e LABREA, 2014: p. 18). Os tipos de instrumentos enumerados pelo IPEA, neste caso, são “conveniamentos, prêmios, bolsas, chancelas, avaliações, visitas, relatórios, sistemas de monitoramento e acompanhamento, documentos, cartilhas, procedimentos, indicadores, etc." (ibidem). Conforme enfatizam BARBOSA DA SILVA e LABREA (ibidem):

O tema das políticas públicas e suas relações com os instrumentos de ação é pouco explorado. A maioria das análises se debruça nas atividades e na parte mais visível dos fenômenos relacionados à ação pública, ou seja, os discursos, as ideias, a mobilização dos atores, os fóruns, as agências, etc. Todavia, analisar a ação pública a partir de seus instrumentos e usos é imprescindível, já que toca na questão dos limites e potenciais para a ação.

Diante do exposto, considera-se a análise dos instrumentos como uma boa fonte para a construção de conhecimento sobre a implementação das políticas públicas em questão. Há que se colocar em perspectiva os desafios a serem enfrentados e as possibilidades reais de fazê-lo com o uso dos instrumentos disponíveis, ou mesmo debatê-los e questioná-los. Cabe verificar as nuâncias e os eventuais impasses de cada escolha, os problemas enfrentados, as soluções encontradas e, aqui neste trabalho - em perspectiva comparada - identificar padrões de funcionamento, semelhanças e diferenças. Conforme ressaltam Lascoumes e Le Galès (2007: p. 18):

Policy instruments are very effective indicator to understand and trace policy change over time. In other words, the policy instrument/instrumentation approach points to a stronger focus on the procedural concept of policy, centering on the idea of establishing policy instruments that enable the actors involved to take responsibility for defining policy objectives. [...] it is now through public policy instruments that shared representations stabilize around social issues. [...]

\footnotetext{
${ }^{56} \mathrm{O}$ redesenho do Cultura Viva foi abordado no capítulo 2 deste trabalho.

${ }^{57}$ IPEA - Instituto de Pesquisa Econômica Aplicada
} 


\subsubsection{O pentágono das políticas públicas:}

Há um aspecto da argumentação de Lascoumes e Le Galès (2012) sobre a Sociologia da Ação Pública que vale à pena destacar. Os autores defendem que uma política pública compreende cinco elementos, que se articulam entre si - atores, representações, instituições, processos e resultados (outputs).

Os atores podem ser individuais ou coletivos: [...] são dotados de recursos, possuem certa autonomia, estratégias e capacidade de fazer escolhas. São mais ou menos guiados por interesses materiais e/ou simbólicos.

As representações são os espaços cognitivos e normativos que dão sentido às suas ações, as condicionam e as refletem.

As instituições são normas, regras, rotinas, procedimentos que governam as interações.

Os processos são as formas de interação e sua recomposição no tempo. Eles justificam as múltiplas atividades de mobilização dos atores individuais e coletivos.

Os resultados (outputs) são as consequências, os efeitos da ação pública.

(LASCOUMES; LE GALÈS, 2012: p. 45-46)

A representação gráfica abaixo ilustra a forma como esses cinco elementos interagem, formando o "Pentágono das políticas públicas":

\section{Pentágono das Políticas Públicas}

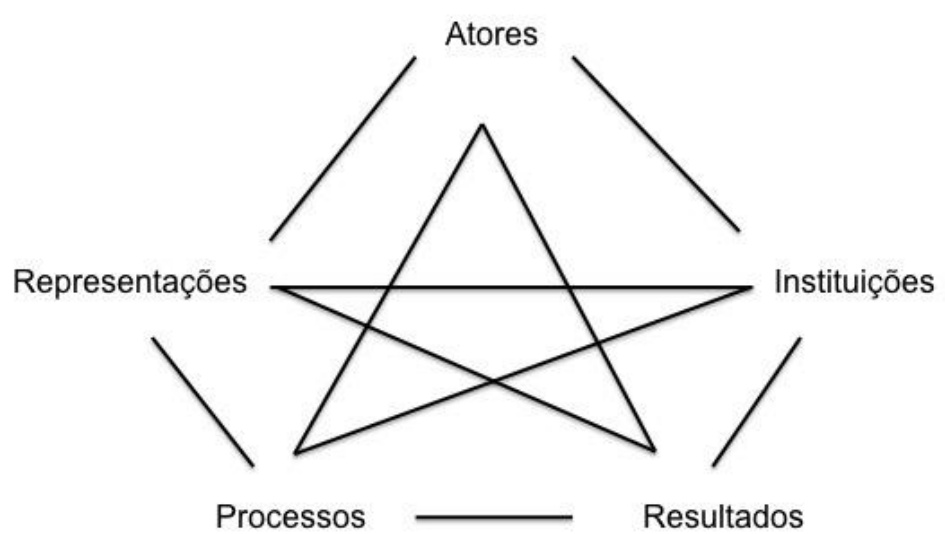

Fonte: LASCOUMES e LE GALĖS (2012: p. 45) 
Tomando por base uma perspectiva "de baixo para cima” da ação pública, e compreendendo que a interação entre autoridades públicas e atores sociais é um aspecto central das políticas públicas, os autores enfatizam que a escolha das prioridades sociais gera debates contraditórios entre atores e interesses. Nesse sentido, devotam grande importância às questões ligadas à implementação, com um olhar para a maneira como os programas públicos são apropriados, e não somente pela forma como são concebidos e estruturados.

Lascoumes e Le Galès (2012, op. cit.) destacam que nos estudos sobre implementação verifica-se que os projetos e programas governamentais são portadores de muitas ambiguidades, o que dá margem aos jogos de poder organizacionais internos , onde os objetivos e prioridades dos atores se acumulam de forma desarticulada. Ademais, há espaço para uma forte atuação do poder discricionário nos procedimentos e na legislação que embasam a ação pública, ou seja, um espaço de atuação relativamente livre à disposição dos atores. Contudo, normas de interpretação, de negociação e de resolução de conflitos atuam num segundo nível, de forma a ordenar localmente a execução dos programas.

Os autores defendem, ainda, que as instituições - enquanto regras, normas, procedimentos e sequencias de ação estandardizadas - fornecem espaço de antecipações que reduz as incertezas e torna possível a ação pública. No entanto, não são neutras, uma vez que os atores que criam as instituições cooperam ou se afrontam na definição das regras e, consequentemente, um processo de institucionalização pode contribuir para privilegiar determinados interesses. (ibidem)

\subsubsection{Contribuições da teoria do ator-rede}

A teoria do ator-rede (LAW, 1992; LATOUR, 2012) tem um enfoque especial sobre a interferência dos objetos nas relações sociais, partindo do pressuposto de que a ordem social é alterada pelos objetos e atores sociais, que funcionam como mediadores no processo heterogêneo de formação e atuação das redes (LAW, 1992).

Como aponta Law (ibidem), o papel da sociologia é caracterizar as formas em que o material se junta para gerar algo e reproduz padrões institucionais e organizacionais nas redes do social. O olhar da teoria do ator-rede, por sua vez, traz uma compreensão razoável de como esses padrões se ordenam e de como os atores se deslocam por entre outros atores e como efetuam suas translações - definidas como deslocamentos por entre outros atores cuja 
mediação é indispensável à ocorrência de qualquer ação (LATOUR, 2001: 356 apud ANDRADE, 2006: p. 57).

É importante notar que translação implica a possibilidade de equivalência, ou seja, a possibilidade de mudança de função de um mesmo objeto ou ator. Por exemplo, um ator pode ser uma rede, ou um mesmo objeto pode funcionar como mediador ou intermediário, a depender do contexto (LAW, 1992).

Conforme verificou-se no capítulo 2, o programa Cultura Viva, no Brasil, caracterizase pela multiplicidade de atores, com uma ampla rede de mais Pontos de Cultura que articulam, desenvolvem atividades, produzem arte e dialogam com seus territórios (GT CULTURA VIVA, 2012). Trata-se de uma rede heterogênea, onde cada Ponto de Cultura também articula e se conecta a outras redes, podendo-se configurar inclusive como um "Pontão de Cultura", que aglutina outros Pontos de Cultura. O programa dialoga, ainda, com uma ideia de política pública que busca vitalizar os movimentos sociais no campo da cultura, democratizando Estado e sociedade (ibidem: p. 54).

Em ensaio preliminar $^{58}$, observei que as características da trajetória dos Pontos de Cultura indicam uma atuação como ator-rede, dadas suas múltiplas conexões tanto em relação à sua comunidade quanto ao Estado. O reconhecimento de um Ponto de Cultura transforma sua relação com o Estado e cria condições propícias para elevar o patamar das relações desse Ponto com sua comunidade e com outros atores sociais (ONGs, Pontos de Cultura, associações de bairro, entidades municipais e estaduais, organismos internacionais e o público em geral).

Segundo a teoria do ator-rede (LAW, 1992; LATOUR, 2012), o Ponto de Cultura poderia ser considerado um ator-rede, pois movimenta-se e dá movimento às ações culturais de uma determinada comunidade, entrelaçando-se com outros Pontos por meio da rede Cultura Viva. No Brasil, o programa apresenta um entrelaçamento de atores e ações que caracterizam uma rede dinâmica, onde é possível identificar os rastros (LAW, 1992) traçados a partir da interação entre Pontos de Cultura e os diversos instrumentos de gestão do programa.

Outra hipótese levantada nesse mesmo ensaio ${ }^{59}$ é que o instrumento de convênio constitui outro ator-rede importante, objeto que molda a ação dos Pontos conveniados com o

\footnotetext{
${ }^{58}$ Título do ensaio: "O programa cultura viva sob a ótica da teoria do ator-rede e abordagens dos instrumentos de gestão" - apresentado como trabalho final da disciplina "Conceitos e Teorias de Políticas Públicas", no $1^{\circ}$ semestre de 2014. Não publicado.

${ }^{59}$ ibidem
} 
poder público, impactando a dinâmica das atividades e sendo modificado pela ação (ou inércia) administrativa dos Pontos. À medida em que se mostra inadequado como instrumento de controle, pela excessiva cobrança de requisitos burocráticos que fogem da realidade dos Pontos de Cultura (ex. exigências de comprovações, formalidades contratuais, regras contábeis de prestação de contas, etc.), o convênio passa a ser um ator-rede que aglutina em torno de si a atenção de diversos outros atores: Ministério da Cultura, Pontos de Cultura, Órgãos de Controle, gestores públicos, gestores dos Pontos e membros da comunidade. Isto porque o cumprimento ou não-cumprimento dos planos de trabalho previstos nos convênios trazem consequências diretas para a dinâmica da relação entre esses atores.

Não será possível desenvolver com profundidade uma análise dos programas selecionados com base na teoria do ator-rede, porém julguei importante agregar a este trabalho os elementos teóricos acima apresentados, pois em muito me auxiliaram na interpretação dos dados e na análise comparada. Destaque-se, ainda, a utilidade de aglutinar esses elementos àqueles apresentados pela abordagem dos instrumentos de gestão. Em especial, nos interessa observar como os atores e instrumentos da política se entrelaçam e se deslocam na implementação dos programas analisados.

\subsection{UMA PROPOSTA DE MODELO DE ANÁliSE DA AÇÃO PÚBLICA CULTURAL}

\subsubsection{Aproximações conceituais e complementaridade das abordagens}

As abordagens teóricas e os modelos analíticos acima descritos forneceram um fio condutor para esta pesquisa, tanto no que se refere à seleção dos dados sobre os programas estudados no capítulo 2, quanto no que tange à análise dos dados em perspectiva comparada, que resultou neste capítulo 3. Não pareceu adequado, entretanto, adotar uma ou outra abordagem isoladamente, visto que são complementares em vários aspectos. Nesse sentido, ao conduzir a pesquisa e iniciar a análise dos dados, debruçando-me sobre as informações coletadas nos diversos documentos e entrevistas realizadas, deparei-me com a necessidade de conectar os conceitos entre as diferentes abordagens, construindo uma espécie de mapa mental que pudesse dar conta da complexidade das políticas culturais em geral e dos programas [brasileiro e argentino] selecionados. 
Tomando por base especialmente o modelo analítico dos Arranjos Institucionais e Capacidades Estatais (GOMIDE; PIRES, 2014a: p. 21, op. cit.) e o Pentágono das Políticas Públicas (LASCOUMES; LES GALÈS, 2012: p. 45, op. cit.), questionei-me se não seria possível aglutiná-los para conceber um terceiro modelo, de caráter autoral, que pudesse refletir meu olhar específico sobre a ação pública na área da cultura. Para isso, poderia ainda tomar emprestados alguns conceitos da abordagem dos instrumentos de gestão e da teoria do ator-rede. A essa altura da pesquisa, eu já havia listado e identificado as principais características dos programas Cultura Viva (Br) e Puntos de Cultura (Ar), orientando-me por esses modelos e pela literatura estudada.

Cabe observar que os dois primeiros modelos partem de ênfases distintas sobre o papel do Estado e os requisitos da ação estatal, porém ambos consideram os efeitos da ação individual dos membros da burocracia e demais atores envolvidos na relação entre Estado e sociedade civil nos processos interativos presentes na ação pública. Outro aspecto importante é a ênfase na combinação de democracia com outros requisitos da ação estatal (GOMIDE; PIRES, 2014) e a crença de que a qualidade dos serviços coletivos sociais fornecidos pelo Estado depende tanto de sua capacidade técnica quanto do aprofundamento da democracia (HERRLEIN JR., 2014).

Pierre Lascoumes e Patrick Le Galès, como adeptos da corrente teórica do construtivismo moderado (SARMENTO apud LASCOUMES; LES GALÈS, 2012: p. 28), reservam em sua formulação teórica um amplo espaço para as instituições e os instrumentos envolvidos nas políticas públicas - ou na ação pública, termo que melhor define o campo de ação estatal. Nesse sentido, compreendem a necessidade de uma interpretação aberta dos interesses dos atores sociais envolvidos, embora considerando que normas, regulamentos, rotinas e diretivas internacionais são também elementos essenciais na formulação de políticas.

A literatura estudada revela, portanto, que ação pública tem se tornado cada vez mais complexa. É no terreno da ação que se enfrentam as questões de ordem prática, envolvendo todos os tipos de problemas na busca da efetividade das políticas. Observa-se, ainda, que os desafios da relação Estado - Sociedade são também de natureza bastante complexa. Não basta anunciar uma política, é preciso que as ações previstas "saiam do papel” e gerem benefícios para os cidadãos. Não é suficiente gerar benefícios para os cidadãos, é preciso fazê-lo com transparência. Não basta ter transparência, é preciso ter mecanismos sistemáticos de controle e prestação de contas à sociedade. Os resultados precisam ser divulgados, analisados e criticados, por meio de processos de escuta, de feedback, de revisão das políticas. 
Mas a sociedade não quer só ouvir os resultados, quer participar da concepção e da implementação dos programas, quer opinar sobre o orçamento, relatar problemas, exigir correção de rumos. Por isso, os processos devem ser questionados, os instrumentos devem ser revisados continuamente, o tempo de execução deve ser medido, o atendimento ao público monitorado, os entraves burocráticos sanados. Ou seja, os processos de feedback devem servir para melhorar as políticas, a partir do diálogo, da escuta da sociedade e do exercício constante da autocrítica. 


\subsubsection{Modelo "Sintonia Fina" (MSF): uma proposta}

Observando os aspectos supramencionados, o esforço de análise empreendido nesta pesquisa permitiu a este autor refletir sobre as categorias de análise e os modelos utilizados, especialmente na tentativa de encontrar parâmetros de comparação entre as experiências brasileira e argentina na implementação de políticas culturais voltadas para a garantia de direitos culturais e cidadania. Desta forma, é possível agregar os elementos analíticos da pesquisa em três campos principais de atenção das políticas públicas na área social, em especial as políticas culturais: Governança, Instituições e Instrumentos. Proponho, portanto, a partir dessa reflexão, o seguinte modelo analítico:

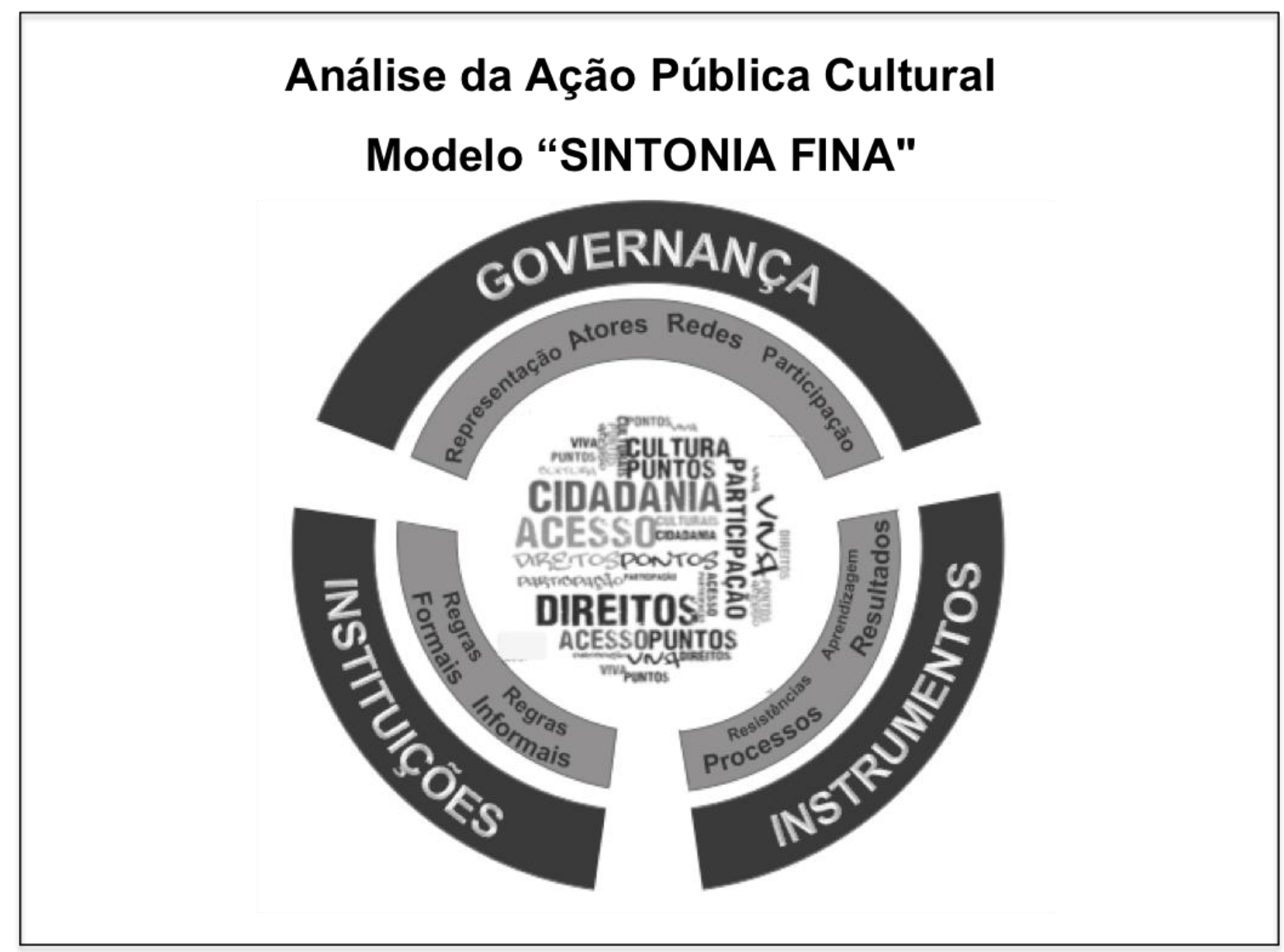

Elaboração: MELO, Bruno H. R.

O modelo acima parte do pressuposto de que as instituições - enquanto regras do jogo - e os instrumentos utilizados na implementação e na gestão das políticas são peças fundamentais para uma análise sob a perspectiva bottom up (de baixo pra cima). É na 
interação desses elementos com os atores envolvidos na política que se pode verificar os entraves causados pelas resistências e os conflitos de poder existentes nas microestruturas e macroestruturas de governança. Por outro lado, o modelo identifica claramente o importante papel desenvolvido pelos diversos atores e redes de atores na sua interação com o Estado e nos diversos mecanismos de participação e representação existentes. Dentre esses atores estão incluídos tanto os membros da burocracia quanto da sociedade civil, entre outros.

Entendo que não há possibilidade de inovar em política pública, em um ambiente democrático, sem prestar a devida atenção às três dimensões incorporadas ao modelo e suas nuâncias internas. Não basta centrar a atenção apenas na movimentação dos atores e nos esquemas de participação e representação - aqui representado pelo campo da Governança. Conforme observou-se nos modelos anteriormente apresentados, esses são aspectos cruciais que impactam diretamente as políticas públicas, mas há que se considerar que atores e redes necessitam de um ambiente institucional para interagir.

São as regras formais e informais - as Instituições - que regulam essas interações e, de certa forma, delimitam seu espaço de influência. Esquemas de participação e representação só podem funcionar se houver uma pactuação clara dos mecanismos e limites institucionais, bem como dos instrumentos utilizados para facilitar essa participação. No campo dos instrumentos, todo processo ou resultado está submetido, por sua vez, aos componentes de poder/conhecimento que atuam na distribuição das tarefas e na administração das resistências (ocultas ou não). Quando os processos não estão claros, essas resistências atuam ainda com maior intensidade, tanto horizontalmente quanto verticalmente.

O formato circular do modelo permite a intercomunicação entre os três campos, os quais se voltam uns para os outros e têm interface direta com o miolo [da figura] que representa o campo políticas culturais e sua diversidade - incluindo questões relativas aos direitos, à cidadania e ao acesso, em suas diferentes representações. No entanto, como será melhor explicado adiante, cada um desses campos é dinâmico e não está rigidamente delimitado, podendo sofrer deslocamentos. Da mesma forma, as políticas culturais no interior da esfera podem se aglutinar mais próximo de qualquer um dos campos, a depender da sua fase de implementação ou de estímulos, restrições e constrangimentos internos ou externos.

O modelo ainda precisa ser testado com maior fôlego, para avaliar sua robustez de análise e para eventuais ajustes e melhorias na sua categorização e nomenclatura, o que poderia ser objeto de futura(s) tese(s). Não obstante, diante de todos os elementos já considerados até aqui nesta pesquisa, parece apropriado indicar que os grandes desafios para a 
relação Estado - Sociedade estão associados a esses três grandes campos da ação pública, em especial no que se refere à implementação de políticas sociais, dentre as quais a política cultural objeto desta pesquisa.

Para melhor compreensão do raciocínio que está por trás da concepção desse modelo, é preciso recorrer a uma analogia com o funcionamento de um aparelho de TV antigo, da época em que os televisores ainda funcionavam com válvulas e tubos de imagem, onde a sintonia dos canais era feita manualmente. Como ilustra a figura ao lado, o botão de sintonia fina das TVs da década de 1970 ficava próximo ao seletor de canais, ou muitas vezes

FIGURA 12

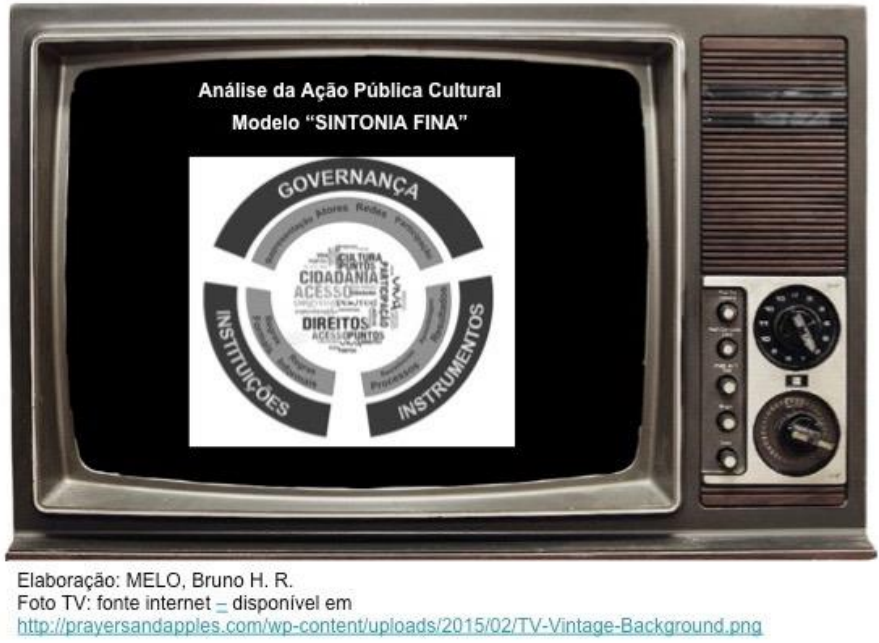
era uma peça adjacente ao seletor, com um formato que se assemelha ao desenho do modelo de análise aqui proposto. A depender da qualidade do sinal de TV que chegasse pela antena, esse botão "mágico" tornava-se uma peça essencial para a calibragem fina da imagem que o expectador veria em sua telinha, ajustando tanto a nitidez quanto o nível de interferência do sinal. A depender das condições da antena e da qualidade do aparelho, esse ajuste poderia ser feito uma única vez, ou sempre que se notasse alguma piora na qualidade da imagem.

O seu manuseio requisitava um usuário paciente e habilidoso - talvez a primeira virtude fosse mais necessária - e que não fosse avesso às novas tecnologias. Por ser manual, o ajuste dependia da sensibilidade do usuário, cujo nível de exigência determinava a duração da tarefa. Além disso, a sintonia complementava-se com o calibre de cores e contraste, que poderia depender de outros botões. Enfim, o usuário deveria manter-se sempre consciente de que a sintonia não dependia só dele, mas de uma conjunção de fatores, como a qualidade do aparelho, a qualidade do sinal externo, o direcionamento da antena de TV, as condições do tempo, o padrão de qualidade da imagem de cada emissora, entre outros.

Mas, afinal, o que a tarefa de sintonizar uma televisão velha tem a ver com as políticas públicas? Com algum grau de abstração, pode-se ver claramente essa relação. Basta visualizar o esquema ilustrativo do modelo de análise aqui proposto e pensar no ato de ajustar o botão da sintonia fina. Por analogia, o gestor da política pode ser figurativamente representado como o 
"usuário" [da TV] que pode atuar para ajustar a sintonia de uma política ou de um programa governamental. Assim como no ajuste de uma imagem de TV, a ação pública depende de vários fatores adjacentes, alguns sob controle direto dos gestores públicos, outros não.

De forma análoga, o ponto de calibragem de uma política pública depende de vários fatores, como por exemplo: o posicionamento dos diversos atores envolvidos e sua movimentação no âmbito das diversas redes e instâncias de representação e participação existentes; o grau de legitimidade das regras e normas que interferem na condução da política; o nível de adaptação da política às regras informais e acordos tácitos que gravitam em seu âmbito; o grau de adequação das soluções técnicas e instrumentos de gestão utilizados no apoio à sua implementação; a existência ou não de focos de resistência à implementação da política como um todo, ou parcialmente; a capacidade de aprendizagem dos diversos atores envolvidos para a consequente retroalimentação da política, a partir dos erros e acertos do seu processo de implementação.

Todos esses aspectos estão referidos no modelo analítico proposto, aglutinados em três grandes campos - Governança, Instituições e Instrumentos. A "sintonia fina” da política pode apontar para a necessidade de maior reforço em algum desses campos, em determinados momentos. O formato circular e contínuo da figura ilustrativa do modelo, entretanto, sugere que não há um ponto específico de início ou fim, ou um "ponto ótimo" que seja fixo. Assim como na sintonia fina de uma TV, o ajuste deve ser feito manualmente, direcionando as energias para os pontos em que se sentir maior necessidade, mas com constante atenção aos fatores externos que podem ocasionar eventuais "interferências" no processo e impactar os resultados.

A nuvem de tags presente no centro da figura, por sua vez, faz uma alusão à passagem da era analógica à era digital, bem como à convivência dos diferentes modos de pensar. Ilustra-se, desta forma, a complexidade inerente à tarefa de calibragem das políticas públicas em meio a uma profusão de anseios e necessidades da contemporaneidade. Assim como em uma nuvem de tags, o ordenamento disso tudo é variável, está em constante mutação, a partir das ênfases que cada tema ganha em determinado momento. Posicionando-se no centro da figura, aspectos como a garantia de direitos, a conquista da cidadania, o aumento da participação social e a ampliação do acesso constituem-se, ao mesmo tempo, nos fins e nos meios da ação pública cultural. Neste sentido, a estrutura de governança, o grau de institucionalidade e o nível de adequação dos instrumentos de uma política, ao mesmo tempo, 
impactam e são impactados pelos aspectos que constituem a própria finalidade das políticas culturais e sociais.

Por fim, o esquema analítico também sugere que as novas demandas da sociedade contemporânea e os novos desafios advindos do uso da tecnologia - em constante mudança devem harmonizar-se com as diferentes culturas e os modos de fazer tradicionais, as regras informais e os códigos e protocolos já estabelecidos. A ideia de uma nuvem de tags remete, ainda, à possibilidade de reconfiguração das relações entre os temas, assim como de uma mudança de olhar possível a partir do que na linguagem comum do ciberespaço pode ser chamado de "F5", ou "refresh" - ou seja, uma "atualização" nos objetivos, meios e finalidades da ação pública.

Recorreu-se aqui à analogia com uma atividade do cotidiano, para ilustrar de forma simplificada uma relação que é entretanto cada vez mais complexa. O exercício de análise que será apresentado na seção seguinte deste capítulo leva em conta todos os aspectos aqui levantados e os fundamentos teórico-metodológicos mencionados. Como uma primeira aplicação do Modelo "Sintonia Fina" (MSF), a seção será estruturada em três subseções, cada uma correspondendo a um dos campos de análise propostos no MSF - Governança, Instituições e Instrumentos -, abordando uma leitura comparativa dos principais aspectos dos programas Cultura Viva (Br) e Puntos de Cultura (Ar) descritos no capítulo precedente. Ao mesmo tempo, farei um esforço de aproximação dessa análise comparada com os desafios contemporâneos levantados no capítulo 1, conectando assim os conceitos explorados ao longo desta pesquisa.

Cabe ressaltar que o objetivo aqui não é a comprovação da eficácia ou validade do modelo MSF, que tão somente será utilizado com vistas a organizar a análise da forma que me pareceu mais adequada. Pela característica interdisciplinar desta dissertação, não há a intenção de se submeter à rigidez de um ou outro modelo, mas pelo contrário, aproveitar os aspectos mais relevantes de cada abordagem para construir uma análise consistente e devidamente embasada. Futuros trabalhos poderão vir a explorar com maior vigor a aplicação ou o teste de validade do modelo MSF. O modelo MSF servirá, por hora, para emoldurar a análise, utilizando os conceitos apresentados e discutidos ao longo deste trabalho. 


\subsection{Análise comparada: Cultura Viva (Br) X Puntos de Cultura (Ar)}

Os programas Cultura Viva (Br) e Puntos de Cultura (Ar) foram descritos e analisados separadamente no capítulo anterior. Vistos isoladamente, apresentam-se como experiências independentes que se cruzam essencialmente quando o seu conceito é colocado em primeiro plano. Propositadamente, não foram realçados detalhes sobre os aspectos relacionados à transferência de tecnologia entre os dois países, em relação à própria nomenclatura e aos princípios básicos dos programas. O olhar desta pesquisa é outro, focado na implementação e na ação pública propriamente dita.

Nesse sentido, considerando as reflexões teóricas apresentadas, cabe aqui situar esses programas nos campos de análise do modelo MSF, em perspectiva comparada. Colocar um programa ao lado do outro tende a realçar as fragilidades e fortalezas de ambos, mas principalmente pode trazer pistas sobre os seus rumos e alternativas enquanto política pública.

Ficou evidenciado na descrição dos programas que os mesmos são bastante similares quanto a seus conceitos, valores e objetivos, mas com estratégias de operação diferenciadas e adaptadas ao contexto de cada País. Está na base conceitual de ambos o apoio a iniciativas culturais já existentes nos segmentos de base das culturas populares, minorias e periferias urbanas, bem como o enfoque preponderante na garantia do exercício do pleno gozo da cidadania e dos direitos culturais.

Os programas compartilham, ainda, dos mesmos princípios e valores calcados no tripé autonomia-protagonismo-empoderamento, revelando uma postura de reforço do papel do Estado na promoção desse valores. Essa visão é acompanhada nos dois países pela perspectiva de construção da política pública "de baixo para cima”, com reforço das estruturas de participação e da lógica de atuação em rede. Isso fica evidente no esforço de ambos para construir um ambiente de governança adequado a essa lógica.

As escolhas feitas ao longo dos programas e as circunstâncias específicas de cada País, entretanto, revelam que os diferentes percursos adotados estão especialmente associados às distintas características institucionais e aos instrumentos adotados em cada caso. Isso traz à luz alguns aspectos relacionados ao desenvolvimento de novas capacidades estatais que possam dar sustentação às políticas nessa área. Apesar das diferenças de escala, é possível traçar um paralelo entre os dois programas nos três campos de análise a serem explorados a seguir. 


\subsubsection{Governança}

Conforme o modelo MSF, o ambiente de governança da ação pública cultural inclui os diversos os atores e as redes nas quais operam, bem como os mecanismos de representação e participação presentes numa determinada política. Em ambos os casos aqui estudados, esse ambiente é bastante complexo, envolvendo uma gama considerável de atores que participam de múltiplas redes, com características e objetivos diversos. Ambos os programas também procuraram criar mecanismos de interação e intercâmbio visando ao fortalecimento da redes já existentes e ao estímulo à formação de novas redes - temáticas, territoriais, virtuais, ou ligadas a alguma expressão cultural específica. Porém, as instâncias de participação e representação criadas em cada programa obedecem a dinâmicas próprias da realidade de cada País.

Uma das primeiras constatações sobre os principais atores desses programas (os próprios Pontos e Puntos de Cultura) é a transcendência do seu papel na sociedade. Os documentos de avaliação e relatos evidenciados em pesquisas revelam que de fato os programas dos dois países têm criado espaço para o fortalecimento do protagonismo interno e externo dos gestores e organizações participantes em seus ambientes de origem. A chancela estatal para os Pontos de Cultura fortalece a sua imagem como um todo perante a sociedade.

Nesse sentido, os Pontos e Puntos de Cultura surgem também como novos atores sociais importantes na definição das políticas culturais como um todo. Nos dois países, tornase cada vez mais difícil conceber políticas públicas culturais que desconsiderem a existência desses atores, cujas demandas refletem os anseios de uma parcela da sociedade que representa uma ação cultural de resistência na luta pela garantia dos direitos culturais e pelo acesso aos meios de produção e difusão de seus conteúdos e práticas culturais. Na medida em que são reconhecidos pelo Estado e recebem chancela federal para as atividades que exercem, os Pontos e Puntos passam também a influenciar e a ter voz no debate sobre as políticas culturais.

No caso brasileiro, isso pode ser percebido não só nos documentos oficiais e nas falas da coordenação do programa, mas também pela existência de diversas instâncias de representação e participação onde têm assento representantes dos Pontos. Dentre as principais instâncias estão a Comissão Nacional dos Pontos de Cultura (CNdPC), os Comitês Gestores Comunitários dos Pontos e Pontões, as comissões estaduais e municipais dos Pontos de Cultura e os diversos comitês técnicos temáticos e grupos de trabalho com a participação dos 
Pontos, além da representação dos Pontos no Conselho Nacional de Política Cultural (CNPC) e nos colegiados que o compõem, dentre outros âmbitos.

$\mathrm{Na}$ Argentina, os Puntos de Cultura surgem com o mesmo espírito. Conforme apuramos nesta pesquisa (informação verbal ${ }^{60}$, embora ainda não haja espaços formais de representação dedicados exclusivamente aos Puntos - como a CNdPC no Brasil - há indícios de que os Puntos não somente começam a ocupar um lugar de destaque em suas comunidades locais e respectivas redes (ARGENTINA, 2015), mas também passam a opinar na concepção das políticas culturais como um todo. Nesse sentido, cabe citar a menção feita pela coordenação do programa sobre a importância da participação dos Puntos na discussão de temas para inclusão no anteprojeto da Ley Federal de las Culturas, em processo participativo lançado pelo Ministério da Cultura argentino entre novembro de 2014 e maio de $2015 .{ }^{61}$

Segundo um membro da direção do programa, a mencionada lei "pretende ser o marco legal mais amplo para garantir a cultura como um direito universal e garantir a gestão conjunta entre os distintos setores da sociedade, não apenas do Estado" (informação verbal) ${ }^{62}$. Nesse sentido, foi intensa a participação dos Puntos de Cultura e das representações de Cultura Comunitária no debate sobre a lei, incorporando a visão das organizações comunitárias e a pluralidade de vozes. Ao todo, foram realizados cerca de 100 debates em todo o País para construir o projeto de lei, que àquela altura (junho/2015) tramitava no parlamento nacional. $\mathrm{O}$ debate do anteprojeto de lei teve ampla participação também da Frente de Artistas y Trabalhadores de las Culturas, que promoveu 46 fóruns de discussão, com a participação de cerca de 12 mil pessoas e 2 mil organizações, além de 34 povos originários e 23 universidades públicas. ${ }^{63}$

No Brasil, a participação ativa no debate das políticas públicas voltadas para a cidadania cultural e as pressões políticas dos Pontos de Cultura, grupos culturais, e movimentos sociais também foram importantes para a obtenção de avanços e conquistas do programa Cultura Viva, em especial a aprovação da Lei n ${ }^{\circ} 13.018$ - Lei Cultura Viva. Não se pode ignorar que esse processo se assemelha às lutas sociais do movimento operário que foram, em um dado momento, cruciais para a obtenção de concessões do Estado capitalista e as conquistas relacionadas à cidadania social (SANTOS, 1999).

\footnotetext{
${ }^{60}$ Entrevista IV [julho 2015].

${ }^{61}$ Ver 21 pontos para debate no link: http://www.cultura.gob.ar/noticias/la-ley-federal-de-las-culturasproxima-a-convertirse-en-anteproyecto/

${ }^{62}$ Entrevista IV [julho 2015].

${ }^{63}$ Maiores informações, acessar: http://www.cta.org.ar/hacia-una-ley-federal-de-las-4016.html
} 
Os aspectos acima elencados demonstram a importância dos Pontos e Puntos de Cultura, em ambos os países, enquanto atores que potencializam a realização dos direitos culturais de quarta geração consubstanciados na participação na definição das políticas culturais. Segundo VARELLA (2014: pp. 64-65), “esses direitos estão relacionados à possibilidade de interferência direta da sociedade nos rumos das ações estatais, implementadas através de programas culturais" e representam o empoderamento político dos indivíduos na área cultural e o exercício de sua prerrogativa de participação cidadã. Cabe mencionar, por oportuno, que os direitos culturais de quarta geração se constituem a partir do direito à democracia, o direito à informação e o direito ao pluralismo (BONAVIDES, 2010 apud VARELLA, 2014).

Neste sentido, ao Estado não cabe mais apenas implementar políticas culturais democráticas e plurais. Ele próprio deve ser democrático e plural na criação de ferramentas de escuta e participação sociais. Deve, portanto, ouvir os setores que serão objeto das políticas [...], com canais efetivos de participação, para estruturar e dirigir tais políticas. Além disso, deve agora municiar a sociedade com toda a informação pública necessária ao diagnóstico dos setores culturais, com números, indicadores, atividades administrativas, problemas relacionados e propostas de soluções, de modo a qualificar os indivíduos para participação e ampliar o debate público. (VARELLA, 2014: pp. 65-66)

A experiência argentina, assim com a brasileira, também é marcada por uma forte carga simbólica de caráter político. Conforme enfatizou um gestor do programa Puntos de Cultura (informação verbal) ${ }^{64}$, o projeto político é calcado na necessidade de se ampliar direitos - e também recuperar alguns direitos eliminados em processos políticos anteriores - , em "uma perspectiva democratizadora da sociedade, dos meios de produção e da cultura". Trata-se de viabilizar o acesso e democratizar a produção de conteúdos culturais, e não apenas viabilizar o acesso a conteúdos já produzidos. Entende-se que os setores populares produzem cultura todos os dias e necessitam de ferramentas (e recursos) para incrementar essa produção e visibiliza-la à sociedade como um todo. Por isso, torna-se crucial para o programa a perspectiva de conectar os atores da sociedade em uma rede nacional de Puntos de Cultura.

A esse propósito, há que se ressaltar ainda que o esforço de ambos os programas no sentido da ampliação do acesso aos meios de produção e a incorporação de novos atores caracterizam a promoção da democracia cultural como finalidade maior, substituindo a

\footnotetext{
${ }^{64}$ Entrevista II [julho 2015].
} 
simples promoção do acesso a bens e serviços - que caracterizaria apenas a democratização da cultura (BARROS e ZIVIANI, 2011 apud MELO; MAKIUCHI, 2014).

Outra questão a ser destacada sobre o papel dos Puntos enquanto atores do processo político na Argentina diz respeito à própria dinâmica de atuação das organizações comunitárias e de bairro naquele País, bem como ao engajamento político de alguns Puntos enquanto parte da sociedade civil argentina - nas lutas históricas contra a ditadura e em atividades de resistência nas periferias. Em uma das entrevistas com representantes de um Punto de Cultura na periferia de Buenos Aires, ficou claro que o reconhecimento enquanto Punto vinha a reboque de um engajamento histórico daquela organização que já possuía uma ampla rede de conexões, no comando de uma rádio comunitária local e de trabalho voltado para o empoderamento das mulheres. $\mathrm{O}$ envolvimento com o programa governamental fortalecia de alguma maneira esse trabalho, trazendo mais possibilidades de conexões, porém talvez fosse ainda mais importante o aporte do próprio Punto ao programa enquanto ator político empoderado e com capacidade de agregar outras organizações em torno das batalhas políticas de resistência cultural.

Quanto às estruturas internas de representação política e de participação dos Pontos de Cultura nas políticas culturais em geral e nas decisões do programa, o campo da Governança mostra-se melhor estruturado no caso brasileiro do que no argentino. No entanto, nota-se que a profusão de instâncias de participação e representação (colegiados, grupos de trabalho, comitês, comissões) leva à necessidade de concertação entre essas instâncias, para evitar duplicidade de propostas e promover a rotatividade de representantes.

Há indícios da existência de uma disputa pelo protagonismo político de determinados representantes de Pontos ou de redes locais e regionais no âmbito da rede nacional de Pontos de Cultura. Essa percepção está presente nos relatos dos gestores do programa e na observação da dinâmica de reuniões consultivas ou deliberativas. Isso se evidenciou, mais recentemente, nas discussões sobre o processo de escolha dos novos membros da Comissão Nacional dos Pontos de Cultura (informação verbal) ${ }^{65}$ e no debate sobre os novos rumos do programa a partir da certificação de Pontos pelo processo da autodeclaração (ABERTURA, 2016).

Nesse sentido, a rotatividade e/ou alternância de representantes nos diversos fóruns e instâncias de existentes tem sido uma das principais preocupações da atual gestão do MinC,

\footnotetext{
${ }^{65}$ Entrevista VIII [março 2016].
} 
desde o início de 2015 (BRASIL, 2015). Questionamentos sobre a legitimidade de representação e reações adversas a propostas de renovação dos colegiados existentes trazem o tema para o centro das atenções, gerando um aprendizado importante para o programa.

No caso argentino, até onde esta pesquisa pôde apurar, não está na ordem do dia o tema da representação formal dos Puntos de Cultura em instâncias consultivas ou deliberativas do Ministério da Cultura. Não foi possível identificar a existência de comitês ou comissões paritárias ou exclusivas dos Puntos para deliberações a respeito do programa, nem tampouco essa questão apareceu como reivindicação prioritária dos Puntos na avaliação de impacto realizada recentemente (ARGENTINA, 2015).

O impacto mais efetivo do programa, até o momento da referida avaliação, parece estar relacionado aos aspectos simbólicos de valorização da sua identidade e visibilidade social e política nos territórios, bem como ao fortalecimento das organizações, do ponto de vista de sua organização interna e da sua capacidade de estabelecer vínculos com outros atores sociais de sua comunidade ou de âmbito nacional. $\mathrm{O}$ impacto quanto ao trabalho em rede ainda é diverso, com níveis variados de efetiva conexão, comunicação e trabalho conjunto com outros Puntos.

Quanto à atuação em rede, não há como avaliar o grau de coesão da rede nacional dos Pontos e Puntos em cada País, porém percebe-se que as múltiplas redes (temáticas, regionais, etc.) existentes se entrelaçam e são percebidas como importantes ou fundamentais, tanto pelos órgãos de governo como pelos beneficiários da política. A força dos Pontos de Cultura, enquanto atores da política, entretanto, mostra-se tanto mais fortalecida quanto maior o seu grau de atuação em rede. A formação de redes temáticas, regionais e estaduais de Pontos de Cultura, especialmente no Brasil, tende a reforçar o poder de barganha dos Pontos e a dar organicidade para sua ação no território, tanto em nível local quanto nacional.

O programa Cultura Viva $(\mathrm{Br})$ apresenta um entrelaçamento de atores e ações que caracterizam uma rede dinâmica, onde é possível identificar os rastros traçados a partir da interação entre Pontos de Cultura e os diversos instrumentos de gestão do programa. O Ponto de Cultura pode ser considerado um ator-rede (LAW, 1992; LATOUR, 2012), que movimenta-se e dá movimento às ações culturais de uma determinada comunidade, entrelaçando-se com outros Pontos por meio da rede Cultura Viva.

A situação em que essa característica se mostra de maneira mais intensa é no caso dos Pontões de Cultura, que funcionam como nós dessa rede mais ampla, atuando fortemente como ator-rede em âmbito regional e fazendo a mediação entre as instâncias governamentais 
- dos níveis federal, estadual e municipal - e Pontos de Cultura, bem como outros atores locais. O Pontão tem, portanto, como principal característica a capacidade de articulação de várias redes, constituindo um elemento central para potencialização do alcance da rede e da efetivação das políticas no âmbito do Cultura Viva.

O caso argentino não conta com uma figura equivalente ao Pontão na estrutura formal do programa. As experiências mais próximas disso seriam, talvez, a linha de apoio dos chamados Círculos de Cultura e do Punto de Cultura Integral, que dispõem de instalações físicas próprias e possuem maior tempo de atividade prévia. No caso dos Círculos de Cultura, destacam-se as atividades de formação e o seu alcance nas comunidades locais enquanto centros culturais, porém existem apenas sete Puntos com essas características - o que representa $1,5 \%$ do total de Puntos de Cultura (450). Some-se a isso que a linha de apoio aos Círculos de Cultura foi lançada apenas uma vez como parte do Plano Nacional de Igualdade Cultural, donde se apresentaram 24 projetos e foram escolhidos sete.

Há inúmeros outros atores envolvidos nos programas em cada País. No entanto, vale destacar o papel de alguns atores específicos que compõem o complexo emaranhado de relações no campo da governança do programa, em especial no Brasil.

Nesse sentido, destaca-se a importância dos órgãos de controle (CGU, TCU) e dos funcionários técnicos do Ministério da Cultura, como atores da burocracia estatal decisivos no processo de prestação de contas das ações realizadas. A escolha do instrumento de convênio como ferramenta de implementação do programa torna esses atores peças-chave, considerando a margem de interpretação e flexibilização possível (ou não) nos termos da legislação vigente, como se verá a seguir na discussão sobre instrumentos. $\mathrm{O}$ alto percentual de prestações de contas questionadas e/ou reprovadas volta as atenções para esses atores e sugere a necessidade de uma concertação entre gestores da política e os distintos atores que influenciam os processos de controle e transparência, visando a calibrar as expectativas e buscar soluções alternativas para lidar com as especificidades dos atores beneficiários da política, no caso os Pontos de Cultura.

Ainda quanto ao Brasil, os parlamentares do Congresso Nacional surgem como peça fundamental na aprovação da Lei Cultura Viva, a partir de projeto de lei apresentado pela Deputada Federal Jandira Feghali, respondendo a uma mobilização da base dos Pontos de Cultura que se movimentaram a partir de articulações em sintonia com vários outros países da América Latina, em torno da ideia do fortalecimento da Cultura Viva Comunitária 
(informações verbais) $^{66}$. A experiência do programa Cultura Viva sugere, ainda, que a mobilização dos atores da base social da cultura junto aos congressistas para aprovação de uma lei específica torna-se um elemento-chave cuja força não pode ser negligenciada.

Isso consubstancia, na prática, a efetivação de dois componentes centrais presentes na concepção do programa, quais sejam o "protagonismo" e o "empoderamento". A esse respeito, um gestor do Ministério comentou em entrevista (informação verbal) ${ }^{67}$ que tem se tornado cada vez mais perceptível o fortalecimento dos representantes de pontos de cultura enquanto atores políticos engajados. Isto porque, segundo ele, a política cultural "dá visibilidade, amplia e permite o reconhecimento desses atores e o seu empoderamento no processo político enquanto sujeitos sociais". Nesse sentido, vários desses gestores e "fazedores de cultura" de Pontos se tornaram também agentes políticos - em nível nacional ou em suas comunidades -, ampliando a capacidade de reconhecimento e de vocalização de determinados segmentos.

Registre-se, ademais, a crescente incorporação de novos grupos e coletivos culturais ligados à cena cultural independente e aos movimentos de periferia, assim como às atividades de mídia livre - pela via da autodeclaração e pelas novas interações com o Ministério. Esses novos atores incorporam-se rapidamente ao sistema e às diversas redes do Cultura Viva e da dinâmica cultural como um todo, aportando sua experiência de atuação nas redes sociais e com a cultura digital hacker. Passam a ser atores importantes na ampliação do campo de atuação da cultura e na defesa dos valores e princípios democráticos, do respeito à diversidade cultural e da luta pelos direitos culturais das minorias (BRASIL, 2015; BENTES, 2015).

Como conclusão complementar, embora não tenha sido este o foco desta pesquisa, a análise do caso brasileiro indica que não houve direcionamento político-partidário na destinação de recursos do programa Cultura Viva executados de forma descentralizada com estados e municípios, considerando que foram firmados convênios entre o MinC e todos os estados da federação, entre 2004 e 2012, conforme dados analisados pela Controladoria Geral da União (CGU) em relatório de acompanhamento desse órgão elaborado em 2013. (BRASIL, 2013b)

O relatório supracitado utiliza dados do Relatório de Gestão de 2012 da Secretaria da Cidadania e da Diversidade Cultural do Ministério da Cultura (SCDC/MinC) demonstrando que, de 2004 a 2012, o MinC efetivou convênios e apoiou a implementação de 3.663 Pontos e Pontões de Cultura, em todos os 27 estados, incluindo o Distrito Federal. Os estados do

\footnotetext{
${ }^{66}$ Entrevista VII [fevereiro 2016].

${ }^{67}$ Entrevista VII [fevereiro 2016].
} 
Ceará, Rio Grande do Sul, Bahia, Rio de Janeiro e São Paulo concentraram 2.060 Pontos e Pontões, o que corresponde a 56,24\% do total existente à época, bem como 53,41\% dos recursos descentralizados pelo MinC. (BRASIL, 2013b: pp. 9-10)

Não foi possível tirar conclusões a esse respeito no caso argentino - por ausência ou insuficiência de dados. Observou-se, porém, durante o trabalho de campo realizado, que há uma aparente desconexão entre o programa Puntos de Cultura - de abrangência nacional - e outra iniciativa correlata desenvolvida à mesma época em nível local, envolvendo a Rede Cultura Viva Comunitária de Buenos Aires, qual seja o programa "Cutura Viva Comunitaria" - desenvolvido pela Secretaría de Habitat e Inclusión do Ministério de Desenvolvimento Econômico da Cidade de Buenos Aires. (BUENOS AIRES CIUDAD, 2014)

Vale destacar que o termo Cultura Viva Comunitária tem sido coincidentemente adotado em vários países da América Latina ${ }^{68}$ e está associado à articulação existente entre grupos culturais e organizações sociais de base comunitária de vários países da região, em torno das mesmas premissas dos programas Cultura Viva (Br) e Puntos de Cultura (Ar), bem como de outros programas e experiências similares na região. Trata-se de um movimento que surgiu "de baixo para cima", ou seja, uma articulação em rede que nasceu da própria sociedade civil e encontrou suporte nos governos nacionais e locais de países latinoamericanos. Essa articulação já resultou na criação de algumas redes temáticas em caráter continental, como a Rede Latino-Americana de Teatro Comunitário, bem como na realização do I Congresso Cultura Viva Comunitária - La Paz, 2013 - e do $2^{\circ}$ Congresso LatinoAmericano Cultura Viva Comunitária - San Salvador, 2015. Os dois congressos foram realizados em cogestão pela sociedade civil e os respectivos governos nacionais e locais.

O aumento do grau de articulação desses atores em nível continental influenciou positivamente os governos da região no sentido de aderir à proposta brasileira de criação do Programa IberCultura Viva - um programa de cooperação técnica e financeira voltado para o fortalecimento das culturas de base comunitária dos países ibero-americanos, constituindo-se em um dos Programas de Cúpula impulsionados pela Secretaria Geral Ibero-Americana (SEGIB). O tema tem despertado crescente interesse em âmbito governamental e acadêmico, porém não será tratado em maior profundidade neste trabalho, podendo ser objeto de outros trabalhos e teses.

\footnotetext{
${ }^{68}$ Para maiores informações, consultar os seguintes sítios na internet: http://culturavivacomunitaria.org/cv/ ; http://www.cvcelsalvador.cc/vision-y-objetivos/; http://iberculturaviva.org/. Acesso em 19 fev. 2016.
} 


\subsubsection{Instituições}

Conforme já pontuado neste trabalho, o ambiente institucional envolve o conjunto de procedimentos, normas e convenções de uma comunidade política (HALL e TAYLOR, 2002 apud ACCO, 2009: p. 155). No marco específico dos programas Cultura Viva (Br) e Puntos de Cultura (Ar), esse é um dos campos mais frágeis em vista da escassez e até mesmo ausência - em certos aspectos - de marcos legais nacionais adequados e compatíveis com a realidade das organizações da sociedade civil de base comunitária e periférica. No entanto, alguns avanços vêm sendo alcançados, em especial no que tange ao conjunto geral dos regramentos institucionais da política cultural, notadamente no Brasil.

No caso brasileiro há que se destacar, em primeiro plano, que as regras e orientações legais que regem o programa Cultura Viva - consolidadas pela Lei Cultura Viva e sua regulamentação pela IN 01/2015 - estão inseridas no arcabouço institucional mais amplo que dá suporte à implementação das políticas culturais como um todo, especialmente a partir dos seguintes marcos legais sob a tutela do MinC: o Plano Nacional de Cultura (PNC), o Sistema Nacional de Cultura (SNC), o Sistema Federal de Cultura (SFC) e os regulamentos do Conselho Nacional de Política Cultural (CNPC) e do Fundo Nacional de Cultura (FNC). Tendo em conta as novas funções e capacidades que se apresentam como desafios para a atuação do Estado no contexto aqui apresentado, bem como os conceitos apresentados nas seções anteriores, pode-se afirmar que os marcos legais supracitados têm caráter estruturante e contribuem para a consolidação de um arranjo institucional relativamente robusto para a implementação de políticas culturais voltadas para a garantia de direitos, cidadania e participação social. Contribuem, ainda, para a construção do desenvolvimento, nos termos abordados neste trabalho.

O PNC, instituído pela Lei 12.343, de 2 de dezembro de 2010, é o instrumento de planejamento decenal das ações da área da cultura, até 2020. O Plano foi elaborado pelo método de construção compartilhada, resultado de amplo processo de debates (ROLLEMBERG, 2014; VARELLA, 2014). Apresenta 53 metas relacionadas às dimensões simbólica, cidadã e econômica da cultura, além de prever processos participativos de gestão das políticas culturais e valorizar mais explicitamente os direitos culturais, fortalecendo as capacidades estatais nessa área, conforme salienta VARELLA (2014: p. 187): 
No que tange às consequências concretas para os segmentos culturais, o Plano Nacional de Cultura pode significar um incremento na capacidade das estruturas do Estado para atender às demandas que surgem a partir das novas relações jurídicas da cultura. Amplia-se o alcance do chamado Direito da Cultura, de maneira que ele abarque dinâmicas próprias do mundo cultural, preservando-as e estimulando-as. Além disso, criam-se condições reais de afirmação do direito à cultura e de ampliação da cidadania cultural, com a cultura sendo incorporada como elemento central da vivencia social e como requisito indispensável da dignidade humana.

O Sistema Federal de Cultura e o Conselho Nacional de Política Cultural foram instituídos pelo Decreto $\mathrm{n}^{\mathrm{o}} 5.520$, de 24 de agosto de 2005, com o objetivo de integrar os órgãos, programas e ações culturais do Governo Federal e contribuir para a pactuação com a sociedade civil. O SFC é composto pelos órgãos do MinC e suas entidades vinculadas, e o CNPC tem composição mista, com representantes da sociedade civil.

O Sistema Nacional de Cultura, por sua vez, delimita e distribui as responsabilidades no âmbito do sistema federativo. É um sistema ainda em construção, porém sua conjugação com a complementaridade dos diferentes Entes do pacto federativo brasileiro contribui para o avanço gradual do programa com base na divisão de competências e nivelamento de contrapartidas. Cabe registrar que o ganho de escala obtido no programa Cultura Viva a partir da segunda etapa de sua implementação (2007-2010) só foi possível em virtude da descentralização de recursos do MinC para os estados e municípios.

Portanto, tomando por base o modelo analítico proposto por Gomide e Pires (2014, p. 21), verifica-se que os instrumentos de política e marcos legais supracitados configuram um novo arranjo institucional para as políticas culturais no Brasil, compreendendo a interação da burocracia com instancias de participação, representação e controles, e apontando para a construção de novas capacidades técnicas e políticas que impactam os resultados da política.

$\mathrm{Na}$ Argentina, com a discussão e o início da tramitação da Ley Federal de las Culturas, ainda está em construção um marco legal amplo para as políticas federais naquele País. O Ministério da Cultura foi recém-criado (2014), absorvendo a estrutura da Secretaria de Cultura da Nação, que era até então o órgão máximo de cultura diretamente ligado à Presidência da República. Não obstante, a antiga Secretaria já havia desenhado na última década as bases para a transformação institucional da Pasta da cultura naquele País, introduzindo um conceito amplo de cultura e alinhando a ação do órgão com o projeto político dos governos Kirchner e com as diretrizes de política cultural preconizadas nos diversos foros internacionais de cultura. 
Cabe destacar, ainda, que já tramitou no Congresso Argentino uma proposta de projeto de lei específico para criação de uma política nacional de Pontos de Cultura. A Ley de Apoyo a la Cultura Comunitaria, Autogestiva e Independiente - nome do projeto de lei foi apresentada em 2012 ao Congresso após extenso processo participativo de elaboração, encabeçado pelo Colectivo Pueblo Hace Cultura. Como não seguiu tramitação e perdeu o chamado "estado parlamentario", foi reapresentado em 2013, por um deputado da Unidade Popular, porém também não vingou. Esse processo foi articulado pela sociedade civil e não teve condução do Ministério da Cultura argentino. Ao que tudo indica, o tema ainda está tramitando nas Comissões do Congresso, mas os dados a que tive acesso datam de novembro de $2014 .{ }^{69}$

O esforço argentino de maior fôlego, do ponto de vista institucional, parece ter sido a estruturação de programas governamentais continuados, a partir de um conceito amplo de cultura e com forte ênfase no resgate dos direitos culturais e da cidadania e no fortalecimento das indústrias culturais, além das funções tradicionais de apoio às artes e preservação do patrimônio cultural. Amplo esforço também foi direcionado ao mapeamento das atividades culturais e construção de indicadores para as políticas culturais, resultando na criação do Sistema de Información Cultural de la Argentina $(\mathrm{SinCA})^{70}$, que se tornou referência na América do Sul.

Do ponto de vista do regramento jurídico que abarca as estruturas da burocracia estatal - no sentido weberiano do estabelecimento de uma burocracia profissional - estudo recente concluiu que "a capacidade burocrática não é distribuída uniformemente entre as agências governamentais nem no Brasil, nem na Argentina" (SOUZA, 2016: p. 99). Entretanto, o mesmo estudo argumenta que no Brasil a agenda da redemocratização pós-ditadura buscou pela via constitucional a construção de instituições democráticas sólidas que contassem com a formação de uma burocracia weberiana; ao passo que na Argentina a redemocratização teria dado maior ênfase à punição dos crimes cometidos durante a ditadura militar.

Nesse sentido, há que se ressaltar que, embora a estrutura do Ministério da Cultura brasileiro ainda seja razoavelmente afetada pelas eventuais mudanças políticas - dada a predominância dos ocupantes de cargos em comissão nas funções de direção e

\footnotetext{
${ }^{69}$ Ver: http://www.pagina12.com.ar/diario/laventana/26-246687-2014-05-21.html e http://www1.hcdn.gov.ar/proyxml/expediente.asp?fundamentos=si\&numexp=9268-D-2014 . Acesso em 04 abr. 2016.

${ }^{70}$ Ver: http://www.cultura.gob.ar/sistema-de-informacion-cultural-de-la-argentina-sinca/ . Acesso em 04 abr. 2016.
} 
assessoramento -, a tendência é que a suscetibilidade a esse tipo de mudanças seja menos sentida no Brasil do que na Argentina. Segundo aponta SOUZA (2016: p. 99):

No caso da Argentina, [...] a redemocratização não mudou a forma de recrutamento da burocracia, mantendo as características do passado, ou seja, um sistema burocrático que carece dos requisitos weberianos. Os servidores públicos federais argentinos são regidos por diversos regimes jurídicos, e a maioria é recrutada com base em laços pessoais e/ou partidários. Isso não significa, todavia, que o governo argentino não possua capacidade de formular e implementar políticas, mas, sim, que essa capacidade é restrita a políticas consideradas prioritárias pelos que ocupam o Executivo. A burocracia argentina também carece de regras e procedimentos capazes de diminuir incertezas, ficando submetida aos ciclos eleitorais.

Além desses fatores de caráter mais amplo, vale ressaltar algumas características específicas do ambiente institucional que circunda os programas Cultura Viva, no Brasil, e Puntos de Cultura, na Argentina. Em primeiro lugar, a institucionalização do programa brasileiro por meio da aprovação e entrada em vigor da Lei Cultura Viva elevou o status do programa ao patamar de Política Nacional. Isso representa um avanço que consolida os princípios e objetivos do programa e cria uma relativa blindagem institucional em torno do mesmo, dado que uma política nacional estabelecida por lei é muito menos suscetível aos eventuais percalços advindos de uma alternância política. Em segundo lugar, a nova legislação traz inovações que simplificam os instrumentos de gestão utilizados anteriormente, que representavam o grande calcanhar de Aquiles do programa.

$\mathrm{Na}$ Argentina, por sua vez, o programa Puntos de Cultura ainda não ganhou musculatura nem escala suficiente para transformar-se em política nacional, ficando portanto mais suscetível às mudanças políticas - o que se agrava ainda mais pelas características frágeis da burocracia estatal supramencionadas. No entanto, o programa se beneficia da existência de marcos legais relativamente mais flexíveis que os brasileiros no que se refere às regras de conveniamento e contratualização. Durante a pesquisa de campo, não foram ressaltados pelos interlocutores argentinos grandes entraves referentes a essas regras, o que configura situação completamente diferente do Brasil. A legislação argentina também é mais favorável do ponto de vista de regras para repasses financeiros e prestações de contas, em que pese a escala menor do programa em relação ao brasileiro.

No que tange às regras informais que operam no ambiente institucional dos dois países, a experiência brasileira mostra que não se pode negligenciar a importância e a força dessas regras e procedimentos nas burocracias estatais, bem como das tradições e modos de organização das diferentes entidades e manifestações culturais, que devem ser 
compatibilizados a partir do diálogo, da transparência e do acompanhamento sistemático das ações nessa área.

No Brasil, por exemplo, o instrumento de convênio tem se mostrado inadequado para lidar com a realidade dos Pontos de Cultura que, por suas características intrínsecas, normalmente trabalham com alto nível de informalidade e baixo grau de organização administrativa. A complexidade da situação fica evidente na fase de prestação de contas, onde os Pontos raramente conseguem demonstrar o cumprimento de todos os requisitos formais de comprovação de efetuação de gastos dos recursos recebidos. A regulamentação do Termo de Compromisso Cultural (TCC) no âmbito da Lei Cultura Viva nos termos da IN 01/2015 aparece como uma inovação institucional importante que poderá afetar positivamente o programa, agora transformado em Política Nacional. Além disso, a regulamentação do Marco Regulatório das Organizações da Sociedade Civil (MROSC) - Lei 13.019/2014 - promete resolver outro conjunto de questões que afetam as parcerias com organizações da sociedade civil. A lei poderá beneficiar os Pontos de Cultura pela simplificação de procedimentos administrativos e descriminalização das Organizações da Sociedade Civil, possivelmente gerando entendimentos análogos para serem aplicados nas prestações de contas convênios já celebrados com os Pontos - situação que está em estudo no MinC (informação verbal) ${ }^{71}$. A referida lei entrou em vigor em 23 de janeiro de 2016 para a União e os estados e passará a ter validade para os municípios a partir de $1^{\circ}$ de janeiro de 2017.

Segundo estudo do IPEA (2011), há um forte diferencial entre a linguagem adotada pelo Estado e a dos grupos artísticos e culturais, vinculado ao próprio entendimento que os grupos têm de cultura e do seu fazer cultural. Exemplos desse distanciamento se concretizam, por exemplo, nos processos de contratação de mestres da cultura popular - onde a legislação sobre convênios exige licitação ou procedimento análogo mediante comprovação da qualificação e experiência profissional dos candidatos, mas na maioria das vezes isso não é possível, dado que tais mestres não possuem currículo formal.

Há que se considerar, ainda, a forte carga de poder inerente aos atores governamentais na relação com os agentes culturais dos Pontos de Cultura. $\mathrm{O}$ (des)conhecimento das regras burocráticas é, normalmente, um fator de exercício do poder no nível micro, onde se dão as relações entre burocratas e responsáveis pelos Pontos de Cultura. A excessiva cobrança de requisitos formais, a obsessão pelo controle e pela detecção de irregularidades, a lentidão burocrática e a morosidade de respostas são regras e valores informais que podem atravancar

\footnotetext{
${ }^{71}$ Entrevista IX [março 2016].
} 
os processos e "contaminar" a relação entre o Estado e os beneficiários da política.

Para situar essa questão, vale destacar que durante os primeiros anos de sua implementação o Cultura Viva experimentou na prática a convivência com o chamado “engessamento da máquina pública", na medida em que o programa teve que enfrentar verdadeiros imbróglios administrativos causados, em grande parte, pela inadequação do seu principal instrumento normativo - o convênio - em relação à realidade dos Pontos de Cultura. Entre os vários "problemas" mapeados pela Controladoria Geral da União (CGU), de 2004 a 2012, constavam as dificuldades operativas dos Pontos e Pontões com relação à operacionalização e prestação de contas dos convênios, além de uma estrutura burocrática inadequada da parte do Ministério da Cultura e parceiros estaduais, gerando uma operacionalidade deficiente (GT CULTURA VIVA, 2012). A própria CGU aponta em relatório de acompanhamento do programa em 2013:

Quanto à execução dos convênios, verificou-se que, de modo geral, os objetos dos Pontos de Cultura avaliados não têm sido plenamente executados, conforme autorizado nos Planos de Trabalho, tanto em razão da não liberação de recursos pelos Entes Convenentes, quanto por dificuldades das entidades conveniadas em conseguir gerir de maneira ágil os recursos dos convênios e com aderência aos normativos vigentes, inclusive na realização de despesas inelegíveis e na falta de comprovação de despesas ou não apresentação de prestações de contas. (BRASIL, 2013b: p. 5)

No entanto, em que pese a CGU declarar a existência de erros na condução dos projetos e falhas na prestação de contas, não há consenso entre os membros da equipe técnica e jurídica do MinC sobre a interpretação da legislação pertinente. Relatos de gestores do ministério (informação verbal) ${ }^{72}$ demonstram que muitas vezes essa falta de uniformização no entendimento leva à criminalização da parte mais fragilizada do processo, ou seja, o Ponto de Cultura. Nesse sentido, medidas estão sendo tomadas pela direção do Ministério com vistas a uniformizar esse entendimento e manualizá-los, tomando por base igualmente as atualizações dos marcos legais vigentes.

\subsubsection{Instrumentos}

$\mathrm{Na}$ primeira década de implementação do programa Cultura Viva (Br), a falta de instrumentos adequados e normativas específicas para lidar com a realidade dos diferentes

\footnotetext{
${ }^{72}$ Entrevista IX [março 2016].
} 
atores e grupos culturais pulverizados pelo território induziu o Ministério da Cultura do Brasil a utilizar o instrumento de convênio como principal mecanismo de repasse de recursos para os Pontos de Cultura, ficando sujeito aos problemas de adequação das ações às regras vigentes. Conforme ficou evidente no processo de redesenho do programa Cultura Viva, "o convênio é a espinha dorsal do programa" (BARBOSA DA SILVA e LABREA, 2014: p. 60), tendo servido como marco jurídico da relação com as organizações da sociedade civil e das relações federativas entre a SCDC e órgãos estaduais e municipais, pelo menos nos dez primeiros anos de implementação do programa (2004-2014).

Desta forma, o Ministério acabou por esbarrar na inflexibilidade e inadequação da estrutura normativa adotada pelo Estado brasileiro - à época - para lidar com a realidade dos movimentos culturais de base comunitária, dos pequenos produtores culturais e das diferentes organizações da sociedade civil que atuam no campo dos direitos culturais e da cidadania. Somente a partir da aprovação da Lei Cultura Viva (2014), regulamentada pela IN 01/2015, surgem novas possibilidades de parceria com base no Termo de Compromisso Cultural (TCC) e no mecanismo da certificação pela autodeclaração. Há uma expectativa também de que o novo Marco Regulatório das Organizações da Sociedade Civil (MROSC) possa ser combinado com os dispositivos da Lei Cultura Viva, mas as aplicações específicas ainda estão sendo estudadas nos níveis técnico e jurídico (informação verbal) ${ }^{73}$.

No caso argentino, apesar de também estar submetido à legislação nacional sobre transferência de recursos para entidades privadas sem fins lucrativos, o Ministério da Cultura encontrou soluções específicas para a simplificação de procedimentos, tanto na admissão de propostas quanto na execução dos repasses. Uma das soluções foi desenhar o programa em diferentes linhas de apoio, com requisitos e condições de flexibilidade distintas. Segundo os gestores do programa (informação verbal) ${ }^{74}$, foi possível flexibilizar algumas exigências da legislação a partir de normativas internas lançadas especificamente para atender aos Pontos de Cultura. Outra solução foi firmar parceria com organismo internacional - a OEI - para viabilizar um conjunto de medidas que não seriam possíveis somente pela via do Ministério, em especial as atividades de intercâmbio e algumas questões relativas às organizações de base que não possuem personalidade jurídica.

Na relação direta com os Puntos, portanto, a preocupação maior do Ministério foi em ajustar critérios de seleção e definição do público-alvo, criando linhas de apoio bem definidas

\footnotetext{
${ }^{73}$ Entrevista IX [março 2016].
}

${ }^{74}$ Entrevista I [julho 2015]. 
para seleção via convocatórias públicas. Tais linhas contam com montantes de recursos e prazos de execução diferenciados. Para a execução dos repasses financeiros, foram editadas normas internas que facilitaram o ajuste do instrumento de repasse às características do público-alvo. Isso não quer dizer que o processo tenha sido fácil pois, segundo relatos da equipe técnica do programa (informação verbal) ${ }^{75}$, os problemas surgem durante a implementação e há questões que precisam ser resolvidas caso-a-caso. Mas as eventuais dificuldades com o instrumento de repasse não afetaram de maneira significativa o curso do programa.

No caso brasileiro, o instrumento de repasse aos Pontos de Cultura foi sendo alterado durante as diferentes etapas de implementação, passando do repasse direto para a descentralização via estados e municípios, em seguida para a adoção de alternativas como prêmios e editais diversos, parcerias com Pontões e, finalmente, chegando ao Termo de Compromisso Cultural. Além disso, na fase mais recente, extinguiu-se a condicionalidade do repasse de recursos para que um Ponto de Cultura seja reconhecido, a partir da autodeclaração e da certificação nos termos da Lei Cultura Viva.

Não é demais, portanto, dedicar uma atenção especial a essa sequência temporal, recorrendo a princípios do método do rastreamento do processo - "process tracing" (COLLIER, 2011; BEACH e PEDERSEN, 2013), onde se busca identificar "eventos" ou marcos que possam explicar por que uma política ou uma ação específica teve determinado resultado. Nesse sentido, ao analisar a linha do tempo do programa Cultura Viva, é possível verificar que a trajetória do programa acompanha as escolhas feitas no campo dos instrumentos.

No período 2004-2006, prevalece o convênio direto com pouco mais 600 Pontos dos primeiros editais. De 2007 a 2010, com a adoção da descentralização de recursos para os Estados (via convênio) e com a incorporação dos prêmios (via editais de premiação), há um ganho de escala substantivo, alcançando-se em 2011 a marca dos 3.600 Pontos. Já no período 2011-2013, quando se intensificaram os problemas com prestações de contas de convênios e acentuaram-se os impasses administrativos na gestão do programa, esse número ficou estagnado, voltando a crescer somente em 2013 - a partir do redesenho do programa e retomada de alguns prêmios, chegando a 4500 Pontos em 2014. A partir de 2015, há uma grande expectativa por parte dos gestores do MinC no sentido da ampliação significativa da

\footnotetext{
${ }^{75}$ Entrevista I [julho 2015].
} 
escala do programa a partir da possibilidade de utilização do TCC e da adesão dos novos Pontos pelo mecanismo da autodeclaração. ${ }^{76}$

Os dados evidenciam, portanto, o que esta pesquisa anunciava em suas premissas iniciais, ou seja, que as escolhas relacionadas aos instrumentos de gestão de um programa ou política afetam diretamente os resultados alcançados. Essas escolhas, no caso do Cultura Viva, impactam os resultados a serem atingidos no âmbito do Plano Nacional de Cultura, cujas metas vêm sendo monitoradas ano a ano. Ou seja, afetam diretamente a escala do programa. Essa constatação encontra, ainda, pleno embasamento na abordagens dos instrumentos de gestão e da Sociologia da Ação Pública (MOISDON, 2006; LASCOUMES; LE GALÈS, 2007, 2012), considerando-se que instrumentos não são neutros (MOISDON, 2006) e que organizam relações sociais entre o poder público e seus destinatários (LASCOUMES; LE GALÈS, 2012).

Há, entretanto, uma observação importante a ser feita. Não fosse pelo constante feedback dos atores envolvidos no programa Cultura Viva e pelas pressões que exercem sobre o poder público, bem como pelas pressões que sofrem advindas dos órgãos de controle, muitas das mudanças na implementação da política poderiam não ter sido enfrentadas. Observa-se, todavia, que as resistências não são exatamente direcionadas a toda e qualquer forma de controle, mas sim ao controle excessivo e à utilização de instrumentos inadequados ou insuficientes para as parcerias entre governo e sociedade civil no campo da cultura.

De certa maneira, a interpretação de que o instrumento era inadequado foi absorvida pelos tomadores de decisão, influenciados também pela mobilização política dos Pontos junto a suas redes e ao Congresso Nacional, resultando positivamente na aprovação da Lei Cultura Viva e posteriores atos de regulamentação da mesma. Não obstante, resta ainda acompanhar a aplicação prática das novas regras e avaliar seu impacto sobre o funcionamento e os resultados do programa.

É importante notar que, além de promover avanços políticos importantes, tais pressões operam permanentemente como geradoras de novas aprendizagens na implementação da política, analogamente ao que Moisdon (2006) chama de "conhecimento derivado", ou seja, o conhecimento proveniente das resistências à aplicação dos instrumentos. Isso se refere tanto às resistências individuais quanto às resistências relacionadas a práticas e rotinas já instituídas nas organizações e nas relações interinstitucionais.

\footnotetext{
${ }^{76}$ Os dados aqui utilizados são os mesmos já apresentados no capítulo 2, com suas respectivas fontes.
} 
Outra observação possível é de que o convênio, inicialmente visto como um mero instrumento de repasse de recursos, passa a ser o principal objeto de conflito na relação entre os diversos atores dessa política. Pode-se dizer, neste caso, que o objeto (convênio) torna-se ele mesmo um ator importante no emaranhado de relações dessa rede, já que modifica o curso das ações e deixa rastros durante sua implementação, onde se pode identificar fontes de conflito e jogos de poder na relação Estado-sociedade. Isso seria o que a teoria do ator-rede classifica como um movimento de translação (Latour, 2012; Law, 1992) do instrumento de convênio, que passa da sua função original de intermediário e facilitador dos processos para a função de mediador, na medida em que modifica as relações entre Ponto de Cultura e os órgãos governamentais a partir de sua implementação.

Nessa perspectiva, pode-se dizer o mesmo dos editais e convocatórias utilizados como instrumentos de chamamento público, tanto no Brasil quanto na Argentina. Esses instrumentos também passam da condição de intermediários para mediadores (LAW, 1992), ou seja, são "objetos" que ganham vida a partir de sua interação com os diversos atores (LATOUR, 2012; LAW, 1992). Isso se observa na medida em que a utilização de tais instrumentos modifica processos de interação entre Estado e sociedade civil.

Tradicionalmente, o público-alvo desses programas - artistas, gestores culturais, mestres e "fazedores" de cultura, grupos e comunidades em situação de vulnerabilidade social - não tem familiaridade de lidar com as "complicações" burocráticas e exigências legais dos editais públicos. Quando estes passam a ser utilizados, ocorrem dois movimentos simultâneos: os Pontos e Puntos têm que se adaptar às regras previstas nos editais e convocatórias; e os editas e convocatórias têm que ser adaptados à realidade dos beneficiários. Esse movimento de acomodação é traumático e, muitas vezes, frustrante. Mas é exatamente nessa interação que o objeto ganha vida e passa a modificar sua própria trajetória e a trajetória dos atores da rede. Editais criam regras que precisam ser cumpridas e implantam a noção de critérios e transparência nas ações do Estado; ao mesmo tempo que indicam escolhas territoriais e ênfases temáticas.

No que se refere aos instrumentos e ferramentas de monitoramento e gestão dos programas, há muito o que se avançar ainda, tanto no Brasil quanto na Argentina. As ferramentas nessa área, por hora, concentram-se nas plataformas de registro ou cadastro dos Pontos - na Argentina o Registro Nacional de Puntos de Cultura; e no Brasil a recém criada (2015) Plataforma Rede Cultura Viva, que incorpora o Cadastro Nacional de Pontos e Pontões de Cultura previsto na Lei 13.018. 
Tanto o Registro Nacional argentino quanto a Plataforma brasileira trabalham com a perspectiva de absorver todas as informações possíveis sobre os Pontos/Puntos de Cultura, bem como de outras organizações ou coletivos que se candidatem a editais ou convocatórias realizados pelos ministérios de cultura. Essa abordagem tem um resultado mais concreto no mapeamento dessas organizações e na constituição de um banco de informações dos Pontos e Puntos existentes e em potencial. Diante da dificuldade de manter atualizadas tais informações (ABERTURA, 2016), essas plataformas ainda não atingiram um grau de sofisticação que possa transformá-las em instrumento auxiliar na tomada de decisões das políticas - isso seria, entretanto, uma boa alternativa para o futuro.

No caso brasileiro, cabe registrar que há uma intenção explícita do MinC em transformar a Plataforma Rede Cultura Viva, pouco a pouco, em um instrumento que possa também auxiliar a dinamização da rede nacional de Pontos. Essa perspectiva vem se fortalecendo a partir da introdução do instrumento da certificação baseada na autodeclaração do Pontos de Cultura. Dado o pouco tempo de funcionamento dessas ferramentas, ainda não é possível avaliar ainda se há condições para que isso ocorra de maneira efetiva. Um ponto positivo a ser considerado é que a plataforma se inicia já integrada ao Sistema Nacional de Informações e Indicadores Culturais (SNIIC), o que aumenta sua potencialidade de conexão com outras políticas e, consequentemente, de cruzamento de dados com outras bases de dados georreferenciadas.

A experiência argentina, por sua vez, aponta a existência de grandes desafios para a nacionalização do programa Puntos de Cultura no território argentino, dadas as características de organização do Estado argentino que induz à concentração de ações na capital e na província de Buenos Aires. Os resultados do programa, nesse campo, segundo avaliação dos próprios Puntos (ARGENTINA, 2015), dependem de uma adequação de instrumentos de monitoramento e acompanhamento que permitam uma maior conexão entre a equipe gestora do programa e os dirigentes e equipes dos Puntos no território.

Por fim, cabe registrar que há diversos outros instrumentos associados a cada um dos programas, conforme descrito no capítulo anterior. Não obstante, seria enfadonho aprofundar aqui em uma análise detida de cada um deles em perspectiva comparada. $\mathrm{O}$ exercício comparativo buscou mostrar alguns aspectos relevantes da interação desses instrumentos entre si e com os demais campos de análise do modelo MSF, na ótica deste pesquisador e à luz dos referenciais teóricos estudados. 


\section{CONCLUSÕES}

Esta dissertação abordou os principais aspectos das políticas culturais voltadas para a cidadania e a garantia dos direitos culturais no Brasil e na Argentina, notadamente a partir do estudo comparado entre dois programas de mesma base conceitual implementados nos dois países, respectivamente o Programa Cultura Viva e o Programa Puntos de Cultura. Esta análise se deu a partir do enquadramento desses programas no hall mais amplo das políticas culturais e sua relação com o desenvolvimento.

A questão central que motivou esta pesquisa foi uma inquietação deste autor em buscar entender como ocorre o processo de formulação e implementação de políticas nacionais de cultura e cidadania no Brasil e na Argentina, e o que poderia explicar a trajetória dessas políticas em cada País. Duas experiências similares estavam em curso nos dois países, o que aguçava meu interesse em buscar respostas para uma pergunta de fundo: "Como a política se comporta em contextos diferentes?” .

O que aparentemente parecia ser um típico caso de transferência de tecnologia de um País para outro, entretanto, revelou ser uma rica experiência de aprendizado institucional a partir de referências conceituais comuns, mas com dinâmicas de implementação diferentes. A análise das trajetórias dos dois programas em cada um dos países proporcionou um mergulho a fundo nas nuâncias de sua execução, a partir de referenciais teóricos focados na implementação.

A reflexão inicial sobre a relação entre cultura, desenvolvimento e cidadania mostrouse fundamental para o levantamento de questões mais amplas acerca dos desafios contemporâneos na relação entre a sociedade civil e o Estado. Provou-se essencial fazer essa discussão a partir de um olhar transversal sobre o desenvolvimento, onde as políticas culturais encontram terreno fértil para germinar. Corroborou-se aqui a visão de que cultura e desenvolvimento fazem parte de processos dinâmicos e transversais, que incorporam todas as dimensões das relações humanas e da sua relação com o ambiente. Questinou-se, ainda, o conceito de desenvolvimento enquanto categoria globalizante, trazendo à tona questionamentos sobre novas perspectivas do desenvolvimento a partir de conceitos e características próprias da América do Sul.

Portanto, a partir de um primeiro encadeamento lógico entre cultura - direitos culturais - cidadania - desenvolvimento, fomos agregando outros componentes e criando 
outros encadeamentos que se entrelaçam com esse, em diversos níveis. À medida em que as ideias foram sendo postas, agregaram-se outras relações importantes, como o tripé democracia - participação - representação, que se mostrou presente em todo o percurso, dialogando com o tripé de valores autonomia - protagonismo - empoderamento utilizado nos programas analisados.

Com esse pano de fundo, a análise dos programas Cultura Viva e Puntos de Cultura buscou identificar as principais características de cada experiência e os aspectos em que a noção de desenvolvimento se consubstancia nas políticas culturais voltadas para a garantia dos direitos culturais e a cidadania. Essa análise se pautou por uma visão de que a ação pública se é um sistema de ordem negociada, onde as interações entre os jogos de poder dos atores e das instituições impactam e, de certa forma, orientam a ação pública (LASCOUMES; LE GALÈS, 2012).

Complementarmente, utilizando as abordagens dos arranjos institucionais $\mathrm{e}$ capacidades estatais (GOMIDE; PIRES (2014, 2014a), dos instrumentos de gestão e Sociologia da Ação Pública (MOISDON, 2006; LASCOUMES; LE GALÈS, 2007) e aproximações conceituais com a teoria do ator-rede (LAW, 1992; LATOUR, 2012), propus um modelo de análise da ação pública cultural - Modelo "Sintonia Fina" (MSF) -, para subsidiar a análise comparada dos dois programas objeto desta pesquisa.

Portanto, foi possível falar em capacidades humanas e liberdades, mas também em capacidades estatais e arranjos institucionais. Além disso, a noção de democracia mostrou-se presente em todos os níveis, seja na discussão envolvendo desenvolvimento - pósdesenvolvimento - participação - liberdades - direitos, seja nas diversas conformações dos modelos de análise utilizados que envolveram atores - redes - representação - instituições instrumentos - processos - resultados - controles - burocracia.

Naturalmente, não seria possível fazer todos esses encadeamentos sem contar com ferramentas e modelos de análise que pudessem simplificar a visualização desse emaranhado ideias e argumentos. Ao explorar todos esses elementos durante a pesquisa, observando as diversas representações gráficas dos modelos, optei pela tentativa de propor uma visualização própria, autoral, de todas essas variáveis. Daí surgiu o modelo "Sintonia Fina", baseado no tripé governança - instituições - instrumentos, que incorporou boa parte das visões apresentadas. Não havia pretensão de estar criando algo completamente original, mas havia sim a consciência da coerência desse modelo - enquanto representação da realidade - com os 
aspectos presentes nos demais modelos e lógicas de interpretação estudados. Mergulhei, portanto, nessa empreitada, resultando na análise apresentada no capítulo 3, da qual se pode extrair algumas conclusões mais gerais.

As experiências dos programas Cultura Viva (Br) e Puntos de Cultura (Ar) retratam uma multiplicidade de atores que se entrelaçam nas diversas etapas do programa, apontando para a necessidade de constante aprimoramento dos mecanismos de escuta e de participação. A dificuldade de construir consensos em torno de prioridades, objetivos e meios de atingi-los, obriga o Estado a um esforço contínuo de reinvenção dos mecanismos de participação, considerando os desafios da construção democrática de políticas públicas.

A análise mostra que no início da implementação dos programas houve, portanto, uma maior preocupação com a constituição de um campo de Governança para a política pública, conformando-se espaços de representação e participação, incentivando a formação de redes e a mobilização dos atores em busca de um protagonismo da sociedade. Todavia, a lógica de atuação em rede preconizada nos programas não é auto-suficiente enquanto modelo de implementação de políticas voltadas para públicos tão diversos e plurais. A pluralidade de narrativas, anseios e condições de operabilidade dos Pontos e Puntos de Cultura e dos diversos atores envolvidos em políticas dessa natureza implica a necessidade de constituição e consolidação de instâncias de representação e participação que abarquem essa multiplicidade.

A pré-existência de programas voltados para as organizações sociais de base na Argentina, em contraponto à experiência brasileira, mostrou-se elemento-chave na construção de modelos administrativos e instrumentos mais flexíveis na relação com os Pontos de Cultura. A experiência brasileira iniciou-se a partir de pouca ou quase nenhuma relação direta prévia com os segmentos culturais representados pelos Pontos de Cultura, o que ocasionou uma curva de aprendizado mais intensa durante a implementação. A relação com esses atores, nos dois casos, mostrou-se dinâmica e, portanto, deve constituir-se ponto-chave de atenção na conformação do ambiente de governança de políticas dessa natureza.

Ao contrário do que diria o senso comum, a questão da diferença de escala entre os programas brasileiro (4.502 Pontos) e argentino (450 Puntos) demonstrou não ser um fator relevante para a verificação da trajetória e dos resultados dos respectivos programas, na perspectiva dos campos de análise preconizados no Modelo "Sintonia Fina" (MSF) aqui utilizado. A comparação dos aspectos relativos à governança, às instituições e aos instrumentos permitiu a identificação de parâmetros de convergência e/ou diferenciação entre 
os programas. Some-se a isso a necessidade de se relativizar essa diferença de escala, em nível nacional, tendo em vista a diferença equivalente de população e território entre Brasil ${ }^{77}$ e Argentina $^{78}$. Não obstante, tanto o programa argentino quanto o brasileiro têm desafios a enfrentar no terreno da adequação das regras e procedimentos, proporcionalmente à escala de implementação em cada País.

Os programas de ambos os países apresentam resultados importantes quanto à regionalização e territorialização de ações como meio de implementação de uma política nacional. Cabe destacar que em ambos os casos verifica-se uma distribuição dos Pontos e Puntos por todas as regiões dos respectivos territórios nacionais, sendo que no Brasil há uma relativa concentração no Sudeste e Nordeste, e na Argentina a concentração é maior nas regiões da Província de Buenos Aires e da Cidade Autônoma de Buenos Aires.

Os grandes desafios para a busca do "ponto de sintonia" do programa Cultura Viva (Br) tendem a estar mais fortemente relacionados aos ajustes dos marcos legais que dão suporte à sua implementação, juntamente com a adequação dos instrumentos de repasse de recursos e o desenvolvimento de ferramentas de monitoramento do programa. Esses desafios situam-se, portanto, no campo das instituições e dos instrumentos, e sua superação passa pelo desenvolvimento de capacidades estatais de regulação e gestão.

A chave de sintonia do programa argentino, por sua vez, parece já estar melhor ajustada no campo dos instrumentos, com clara definição de critérios de elegibilidade e mecanismos de apoio bem delineados. Subsistem desafios no campo institucional, que poderão ser parcialmente enfrentados a partir da aprovação da Ley Federal de las Culturas pelo Congresso argentino.

Com base na experiência brasileira, pode-se constatar que as resistências internas da burocracia técnica e a rigidez das normas legais e infra-legais constituem barreiras reais à fluidez da relação o Estado e a Sociedade Civil. O desafio consiste em enfrentar essas questões buscando soluções de adaptabilidade e adequação dos marcos legais à realidade das diferentes organizações culturais. Para isso, é necessário adotar uma postura contestadora a partir do próprio Estado, assumindo a natureza contestadora e contra-hegemônica da própria ação cultural [de base comunitária] como ponto de partida para uma mudança de olhar em

\footnotetext{
${ }^{77}$ População do Brasil: 205.711.767 habitantes, conforme projeção 2016 do IBGE. Fonte: http://www.ibge.gov.br/apps/populacao/projecao/. Acesso em 04 abr. 2016.

${ }^{78}$ População da Argentina: 40.117.096 habitantes, conforme censo 2010. Fonte: IGN http://www.ign.gob.ar/NuestrasActividades/Geografia/DatosArgentina/Poblacion
} 
relação aos diversos atores do meio cultural, com vistas ao redimensionamento das exigências.

As condições de acesso aos meios de produção cultural e de difusão também estão diretamente relacionadas ao arcabouço institucional conformado no âmbito das políticas públicas implementadas nessa área. O incentivo à conformação e mobilização de redes para troca de experiências e intercâmbio no terreno simbólico deve somar-se a um esforço de regramento e construção de marcos legais que deem condições de operabilidade dessas trocas.

No caso brasileiro, observa-se que há uma relação intrínseca entre os instrumentos de gestão adotados e a evolução conceitual e de implementação do próprio programa. Embora enfrentando as dificuldades inerentes à rigidez burocrática, o caminho percorrido pelo programa parece ter sido traçado, em grande parte, a partir das escolhas dos instrumentos adotados - eles próprios exercendo, em seguida, um papel interativo com os gestores e gerando um aprendizado coletivo (MOISDON, 2006).

Pode-se afirmar, entretanto, que a adoção de modelos simplificados de seleção e de contratualização entre os entes estatais e os Pontos de Cultura não significa que os processos serão automaticamente executados de maneira mais simples. A excessiva cobrança de requisitos formais, a obsessão pelo controle e pela detecção de irregularidades, a lentidão burocrática e a morosidade de respostas são regras e valores informais que podem atravancar os processos e "contaminar" a relação entre o Estado e os beneficiários da política. São atitudes que reforçam a autoridade do burocrata e lhe conferem um poder típico da atuação do “intelectual legislador” (BAUMAN, 2010).

A partir da análise comparada dos programas Cultura Viva e Puntos de Cultura, aplicando o modelo de análise MSF, pode-se concluir que nas primeiras fases de implementação de cada programa, dada a baixa institucionalidade dos mesmos, os esforços estatais tendem a se concentrar no campo da governança, para construção e ativação das redes e criação de instâncias de participação. À medida em que o programa ganha maturidade, torna-se cada vez mais importante investir em instrumentos voltados para melhoria dos mecanismos de participação e representação, criando instâncias mais dinâmicas.

Por fim, quanto à aplicação do MSF enquanto modelo de análise da ação pública cultural, pode-se concluir que foi bastante útil no sentido de aglutinar conceitos e delimitar parâmetros de comparação. Futuras aplicações do modelo poderiam incorporar indicadores que permitam uma comparação mais precisa sobre o grau de adequação ou grau de 
desenvolvimento das capacidades estatais em cada caso/política, considerando os três campos de análise - governança, instituições e instrumentos. Tais indicadores poderiam auxiliar também a identificar para que lado pendem os resultados de uma política, de modo a permitir a proposição de ajustes de sintonia e correções de rumos nos programas. Esses são desafios para pesquisa que surgem desta empreitada e poderão servir de inspiração para futuros trabalhos. 


\section{REFERÊNCIAS BIBLIOGRÁFICAS}

ACANDA, Jorge Luis. Sociedade civil e hegemonia. Rio de Janeiro: Editora UFRJ, 2006.

ACCO, Marco Antônio de Castilhos. Para onde vão os Estados Nacionais? - Abordagens da teoria social contemporânea sobre as pressões para a transformação dos Estados nacionais na virada para o Século XXI. Tese de Doutorado, Unicamp, Campinas, 2009, $391 \mathrm{p}$.

AGENDA 21 DA CULTURA (2004). Disponível em: <http://www.agenda21 culture.net/index.php/pt/documents-pt/a21c-pt>

ANDRADE, Jackeline Amantno. Redes de atores: uma nova forma de gestão de políticas públicas no Brasil? Gestão e Regionalidade, n. 64, p. 52-66, 2006.

ABERTURA da Comissão de Certificação dos Pontos de Cultura Autodeclarados. Realização de Secretaria da Cidadania e da Diversidade Cultural - Scdc. Coordenação de Ministério da Cultura - Minc. Brasília: Scdc/minc, 2016. (205 min.), Vídeo Youtube, son., color. Debate sobre o histórico da construção do processo de autodeclaração e certificação simplificada instituídos na Lei Cultura Viva. Provocador/Mediador: Diretor da Cidadania e da Diversidade Cultural, Alexandre Santini. Disponível em: <https://youtu.be/s8e53bYJU6E>. Acesso em: 02 mar. 2016.

ARGENTINA. Ministerio de Cultura. Presidencia de La Nación. Puntos de Cultura - Una política transformadora: Relevamiento y análisis del impacto territorial. Buenos Aires: Ministerio de Cultura, Presidencia de La Nación, 2015. 120 p. Disponível em: $<$ http://puntos.cultura.gob.ar/wp-content/uploads/2015/11/Puntos-decultura_Maquetacio?n-11.pdf>.Acesso em: 19 jan. 2016.

ARGENTINA. Secretaría de Cultura. Presidencia de La Nación. Puntos de Cultura 2011. Buenos Aires: Secretaría de Cultura - Presidencia de La Nación, 2011. 63 p. Primeira publicação do programa, abordando seus fundamentos, componentes e resultados da primeira convocatória.. Disponível em: <http://puntos.cultura.gob.ar/wpcontent/uploads/2015/11/puntos_2011_en_baja.pdf>. Acesso em: 15 fev. 2016.

ARGENTINA. Secretaría de Cultura. Presidencia de La Nación. Puntos de Cultura 2012. Buenos Aires: Secretaría de Cultura - Presidencia de La Nación, 2012. 111 p. Segunda publicação do programa, com resultados da segunda convocatória e dos 7 Círculos de Cultura incorporados à Rede Nacional de Puntos de Cultura.

BARBOSA, Frederico e CALABRE, Lia, Orgs. Pontos de cultura: olhares sobre o Programa Cultura Viva. Brasília: Ipea, 2011.

BARBOSA DA SILVA, Frederico A. e ARAÚJO, Herton E., Orgs. . Cultura Viva: avaliação 
do programa arte, educação e cidadania. - Brasília: Ipea, 2010. 148p.

BARBOSA DA SILVA, Frederico A.. O programa Mais Cultura, o Fundo Nacional de Cultura e o Sistema Nacional de Cultura. In: BARBOSA DA SILVA, Frederico A.; ABREU, Luiz Eduardo (Orgs). As políticas públicas e suas narrativas: o estranho caso entre o Mais Cultura e o Sistema Nacional de Cultura. Brasília: Ipea, 2011.

BARBOSA DA SILVA, Frederico A.; LABREA, Valéria Viana (Orgs.). Linhas Gerais de um planejamento participativo para o Programa Cultura Viva. Brasília: Ipea, 2014.

BARROS, José Márcio; ZIVIANI, Paula. "O Programa Cultura Viva e a Diversidade Cultural". In: BARBOSA, Frederico; CALABRE, Lia (Orgs). Pontos de cultura: olhares sobre o Programa Cultura Viva. Brasilia: Ipea, 2011: pp.61-88

BARROS, Ricardo Paes de; COUTINHO, Diana; MENDONÇA, Roseane. Desafios ao Crescimento Inclusivo Brasileiro. Interesse Nacional, S. L., v. 8, n. 32, p.1-8, 2016. Trimestral. Ano 8, n. 32, janeiro-março 2016. Disponível em: <http://interessenacional.com/index.php/artigos/>. Acesso em: 28 fev. 2.

BAUDRILLARD, J.. Simulacros e Simulação. Lisboa: Relógio D’Água, 1991.

BAUMAN, Zygmunt. A Cultura no mundo líquido moderno. Rio de Janeiro: Zahar, 2013.

BAUMAN, Zygmunt. Legisladores e Intérpretes. Rio de Janeiro: Zahar, 2010.

BAUMAN, Zygmunt. Modernidade Líquida. Rio de Janeiro: Zahar, 2001.

BEACH, Derek; PEDERSEN Rasmus Brun. Process Tracing Methods: Foundations and Guidelines. The University of Michigan Press, 2013.

BECK, Ulrich. Sociedade de risco: rumo a uma outra modernidade. São Paulo: Editora 34, 2011.

BENTES, Ivana. Da Hiperfragmentação ao Estado-Rede: Políticas Culturais no Brasil. Interesse Nacional, S. L., v. 8, n. 29, p.1-7, abr. 2015. Trimestral. Ano 8, número 29, abril-junho 2015. Disponível em: <http://interessenacional.com/index.php/artigos/>. Acesso em: 28 fev. 2016.

BERRY, Frances Stokes; BERRY, William D. Innovation and Diffusion Models in Policy Research. In: Theories of the Policy Process. SABATIER, Paul A. (ed.) Westview Press, 2007.

BOTELHO, Isaura. Dimensões da cultura e políticas públicas. Volume 15; 02. Abril a Junho, 2001. São Paulo.

BRASIL. Ministério da Cultura. Programa Nacional de Cultura, Educação e Cidadania. 
Brasília: MinC, 2005. 63 p. Disponível em: <http://semanaculturaviva.cultura.gov.br/linhadotempo/pdf/publicacoes/SPPC/Cultura Viva_Programa_Nacional_Cidadania_2005.pdf>. Acesso em: 24 mar. 2016.

(2006). Programa Cultural para o Desenvolvimento do Brasil. Brasília: Centro de Gestão e Estudos Estratégicos - CGEE, 2006. 49p.

(2010a). Programa Nacional de Cultura, Educação e Cidadania: Cultura Viva: Autonomia, Protagonismo e Fortalecimento Sóciocultural para o Brasil. Brasília: Ministério da Cultura, 2010a. 66p.

(2010b). Oito Anos de Cultura: As políticas do Ministério da Cultura de 2003 a 2010. Brasília: Minc, 2010b. 143 p.

(2010c). Histórias de Ponto: Lugares e pessoas que fazem a Cultura Viva. Brasília: Minc, 2010. 75 p. Publicação que resultou do Prêmio Histórias de Ponto, realizado em 2009 pela SCC/MinC.

(2015). Articular, mobilizar, apoiar!: Cidadania e Diversidade \#Retrospectiva2015. Brasília: Ministério da Cultura, 2015. Relatório anual de atividades da SCDC/MinC. Disponível em: <https://medium.com/@DiversidadeMinC/cidadaniae-diversidade-em-2015-8fac92fd5d4d\#.3nfqgc3f7>. Acesso em: 05 fev. 2016.

(2013a). Programa Cultura Viva: Orientações. Brasília: Ministério da Cultura, 2013a. 14 p. Brochura de apresentação do programa.

BRASIL. Secretaria Federal de Controle Interno. Controladoria-geral da União - Cgu. Relatório de Acompanhamento da Execução de Programa de Governo n. 42/2013: Ministério da Cultura - Programa/Ação 1141/8886 - Cultura Viva - Arte, Educação e Cidadania. Brasília: Cgu, 2013b.

BRASIL. Lei $\mathrm{n}^{\mathrm{o}}$ 13.018/2014, de 22 de julho de 2014. Institui a Política Nacional de Cultura Viva e dá outras providências. Presidência da República. Disponível em: <http://www.planalto.gov.br/ccivil_03/_Ato2011-2014/2014/Lei/L13018.htm>

BUENOS AIRES CIUDAD. Secretaría de Hábitat e Inclusión - Sechi. Ministerio de Desarrollo Económico. De Villa a Barrio. Buenos Aires, Argentina: Sechi, 2014. 242p. Informe de gestão 2012-2013.

CALABRE, Lia. A problemática do desenvolvimento dentro do campo de construção de políticas culturais. In: Plano da Secretaria da Economia Criativa: políticas, diretrizes e ações, 2011-2014. Brasília, Ministério da Cultura, 2012: pp. 79-101.

CANCLINI, Nestor García. Definiciones en transición. Buenos Aires: CLACSO, 2001.

CARAMANI, Daniele. Introduction to comparative politics. In: CARAMANI, Daniele.

Comparative Politics, 2nd Edition. Oxford University Press, 2011: pp. 1-18. 
CARTA CULTURAL IBERO-AMERICANA (2006). Disponível em: <http://segib.org/cumbres/files/2006/01/Carta-cultural-ibero-americana-PORT.pdf> Acesso em 20 mai. 2015.

CONVENÇÃO DA UNESCO SOBRE A PROTEÇÃO E PROMOÇÃO DA DIVERSIDADE DAS EXPRESSÕES CULTURAIS (2005). Disponível em: <http://www.planalto.gov.br/ccivil_03/_ato2007-2010/2007/decreto/d6177.htm>. Acesso em 10/01/2016.

COLLIER, David. Understanding Process Tracing. Political Science and Politics 44, n. 4, p.p. 823-830, 2011.

COUTINHO, Carlos Nelson. Cidadania e Modernidade. Perspectivas: Revista de Ciências Sociais, São Paulo, v. 22, 41-59, 1999.

CSIKZSENTMIHALYI, Mihaly. Creativity: Flow and the psychology of Discovery and invention. (1st ed.) New York: Harper Collins, 1996.

D’ANGELO, Martha. Pós-modernidade: subsídios para refletir sobre educação. Revista Brasileira de Estudos Pedagógicos, Brasília, v. 83, jan/dez 2002.

DECLARAÇÃO UNIVERSAL SOBRE A DIVERSIDADE CULTURAL (2001). Disponível em: 〈http://unesdoc.unesco.org/images/0012/001271/127160por.pdf>. Acesso em 25 jun. 2015.

DECLARAÇÃO DE SÃO PAULO SOBRE CULTURA E SUSTENTABILIDADE (2012). Disponível em: <http://culturasustentabilidade.blogspot.com.br/2012/06/rumo-rio20.html>. Acesso em 10 jan. 2016.

ESCOBAR, Arturo. O lugar da natureza e a natureza do lugar: globalização ou pósdesenvolvimento? In: LANDER, Edgardo (org.). A colonialidade do saber: eurocentrismo e ciências sociais. Perspectivas latino-americanas. p. 133-168. Colección Sur Sur, CLACSO, Ciudad Autónoma de Buenos Aires, Argentina, 2005.

EVANS, Mark. Policy transfer in global perspective. Hants/England: Ashgate, 2004.

FERREIRA, Juca. A centralidade da cultura no desenvolvimento. In. BARROSO, Aloísio Sérgio; SOUZA, Renildo (orgs.). Desenvolvimento: idéias para um projeto nacional. São Paulo: Fundação Maurício Grabois, 2010. p. 265-278. Disponível em: <http://www.cultura.gov.br/artigos/-/asset_publisher/WDHIazzLKg57/content/acentralidade-da-cultura-no-desenvolvimento-405575/10883.> Acesso em 23 fev. 2016.

FERREIRA, Juca. A economia da cultura e o desenvolvimento do Brasil. In: FÓRUM NACIONAL DO INSTITUTO NACIONAL DE ALTOS ESTUDOS (INAE), 27., 2015, Rio de Janeiro. Palestra Sessão Encerramento. S.1.: Inae, 2015. p. 1 - 5. 
Disponível

em:

<http://www.cultura.gov.br/busca?p_p_auth=A5xrjHv5\&p_p_id=101\&p_p_lifecycle=0

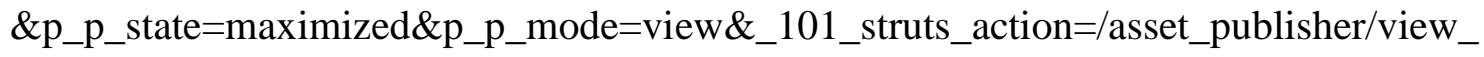
content\&_101_assetEntryId=1277347\&_101_type=content\&_101_groupId=10883\&_1 01_urlTitle=a-economia-da-cultura-e-o-desenvolvimento-dobrasil\&redirect=http://www.cultura.gov.br/busca?p_p_id=3\&p_p>

FIANI, Ronaldo. Arranjos institucionais e Desenvolvimento: o papel da coordenação em estruturas híbridas. In: GOMIDE, Alexandre de A.; PIRES, Roberto R. C. (Org.). Capacidades estatais e democracia: arranjos institucionais de políticas públicas. Brasília, Ipea, 2014: pp. 57-81

GOMES, Eduardo R.. Relações Estado-Sociedade e novas capacidades estatais para o desenvolvimento entre os países do BRICS: o Brasil em perspectiva comparada com a África do Sul e a Índia. In: GOMIDE, Alexandre de Ávila; BOSCHI, Renato Raul (Ed.). Capacidades estatais em países emergentes: o Brasil em perspectiva comparada. Rio de Janeiro: Ipea, 2016. Cap. 3. p. 105-136. Disponível em: <http://www.ipea.gov.br/portal/images/stories/PDFs/livros/livro_capacidades.pdf>. Acesso em: 29 mar. 2016.

GOMIDE, Alexandre de A.; PIRES, Roberto R. C. (Org.). Capacidades estatais e democracia: arranjos institucionais de políticas públicas. Brasília: Ipea, 2014. 385p.

(2014a). Capacidades estatais e democracia: a abordagem dos arranjos institucionais para análise de políticas públicas. In: GOMIDE, Alexandre de A.; PIRES, Roberto R. C. (Org.). Capacidades estatais e democracia: arranjos institucionais de políticas públicas. Brasília, Ipea, 2014: pp. 15-28.

GOMIDE et al. Capacidades estatais e políticas públicas: passado, presente e futuro da ação governamental para o desenvolvimento. In: Brasil em Desenvolvimento 2014. IPEA, 2014.

GT CULTURA VIVA. Relatório "Redesenho do Programa Cultura Viva". Produzido pelo Grupo de Trabalho Cultura Viva. Brasília: IPEA e MinC, novembro de 2012.

HARVEY, David. A Condição Pós-Moderna: uma pesquisa sobre as origens da mudança cultural. São Paulo: Edições Loyola, 1992.

HERRLEIN JR., Ronaldo. A construção de um estado democrático para o desenvolvimento no século XXI. In: GOMIDE, Alexandre de A.; PIRES, Roberto R. C. (Org.). Capacidades estatais e democracia: arranjos institucionais de políticas públicas. Brasília: Ipea, 2014. pp. 83-109.

IPEA. Cultura viva: as práticas de pontos e pontões. Ipea, Coordenação de Cultura. Brasilia: Ipea, 2011. 261p.

KEMAN, Hans. "Comparative research methods". In: CARAMANI, Daniele. Comparative Politics, 2nd Edition. Oxford University Press, 2011. 
LABREA, Valéria Viana; BARBOSA DA SILVA, Frederico Augusto. A rede imaginada e as redes vividas do Cultura Viva: a tensão entre o dizer e o fazer. 2012. Disponível em: <http://participatorio.juventude.gov.br/file/download/219188> .

LASCOUMES, Pierre; LE GALÈS, Patrick. Introduction: Understanding public policy through its instruments - from the nature of instruments to the sociology of public policy instrumentation. Governance, v. 20, n. 1, p.1-21, 2007.

(2012). Sociologia da ação pública. Maceió: EDUFAL, 2012: 244p.

LATOUCHE, Serge. Pequeno Tratado do Decrescimento Sereno. São Paulo: WMF Martins Fontes, 2009. 170 p.

LATOUR, Bruno. Reagregando o social: uma introdução à Teoria do Ator-Rede. Salvador-Bauru: EDUFBA-EDUSC, 2012: 399 p.

LAVILLE, Christian e DIONNE, Jean. A construção do saber: manual de metodologia da pesquisa em ciências humanas. Porto Alegre: Editora Artes Médicas Sul Ltda/ Belo Horizonte: Editora UFMG, 1999: 340 p.

LAW, John. Notes on the Theory of the Actor-Network: Ordering, Strategy and Heterogeneity. Systems Practice, n. 5, 1992: p. 379-93. Disponível em: $<$ http://www.heterogeneities.net/publications/Law1992NotesOnTheTheoryOfTheActorNetwork.pdf $>$

LÚCIO, Magda de Lima et al. Sentidos e Significados de se Planejar Estrategicamente nas Organizações Públicas: Planejamento Estratégico Sociotécnico (PLANES): análise de uma experiência. Nau Social, [s. 1.], v. 5, n. 9, p.151-160, nov. 2014. Semestral. Disponível em: <http://www.periodicos.adm.ufba.br/index.php/rs/issue/view/25>. Acesso em: 26 mar. 2016.

MACHADO, Jurema. Em busca do lugar da cultura no processo de desenvolvimento. In: Plano da Secretaria da Economia Criativa: políticas, diretrizes e ações, 2011-2014. Brasília, Ministério da Cultura, 2012: pp. 78-80.

MARSH, David. and SHARMAN, J.C. Policy Diffusion and Policy Transfer. In: EVANS, Mark. New Directions in the Study of Policy Transfer. Routledge: Mew York, 2010.

MARTÍNEZ, Irene Maciá; DE ANGELIS, Alessia. La perspectiva cultural en el discurso del desarollo. Revista Iberoamericana de Estudios de Desarrollo / Iberoamerican Journal of Development Studies, v. 2, n. 2, pp. 86-105, 2013.

MELO, Bruno H. R.; MAKIUCHI, Maria de Fátima R.. A Lei Cultura Viva e seus significados no contexto da modernidade tardia: desafios para implementação de uma política nacional. Revista Agenda Social (RAS), v. 8, n. 2, p. 70-83, 2014. Disponível em: <http://www.revistaagendasocial.com.br>.

MENEGHETTI, Francis Kanashiro. O que é um ensaio-teórico? Revista de Administração Contemporânea, Curitiba, v. 15, n. 2, pp. 320-332, mar./abr. 2011. 
MOISDON, Jean-Claude. Sur la largeur des mailles du filet: Savoirs incomplets et gouvernement des organisations. In: HATCHUEL, A.; PEZET, E.; STARKEY, K.; LENAY, O. Gouvernement, organisation et gestion: 1'heritage de Michel Foucault. Canada: Les Presses de 1’Université Laval, 2006.

PATURY, Luiz. O MinC e seus programas. In: Frederico A. Barbosa da Silva e Luiz Eduardo Abreu (Orgs). As políticas públicas e suas narrativas: o estranho caso entre o Mais Cultura e o Sistema Nacional de Cultura. Brasília: Ipea, 2011.

PAULIZZI, Cora et al. Aportes geoculturales: Pensar las políticas culturales desde América Latina. In: TASAT, José Alejandro et al (Comp.). Políticas culturales públicas: culturas locales y diversidad cultural desde un enfoque geocultural. Sáenz Peña: Universidad Nacional de Tres de Febrero, 2014. p. 149-164.

PETERS, B. Guy. Aproaches in comparative politics. In: CARAMANI, Daniele. Comparative Politics, 2nd Edition. Oxford University Press, 2011. pp. 34-46.

PINHEIRO, Maurício Mota Saboya. As liberdades humanas como bases do desenvolvimento: uma análise conceitual da abordagem das capacidades humanas de Amartya Sen. Texto para discussão n. 1794, Instituto de Pesquisa Econômica Aplicada. Brasília; Rio de Janeiro: Ipea, 2012.

QUIJANO, Aníbal. Colonialidade do poder, eurocentrismo e América Latina. In: LANDER, Edgardo (org.). A colonialidade do saber: eurocentrismo e ciências sociais. Perspectivas latino-americanas. Colección Sur-Sur, CLACSO, Ciudad Autónoma de Buenos Aires, Argentina, 2005. Disponível em: <http://biblioteca.clacso.org.ar/ar/libros/lander/pt/Quijano.rtf>.

RADOMSKY, Guilherme F. W.. Desenvolvimento, Pós-Estruturalismo e PósDesenvolvimento: a crítica da modernidade e a emergência de "modernidades" alternativas. Revista Brasileira de Ciências Sociais (RBCS), v. 26, n. 75, p. 149-193, fev. 2011.

REDESENHO do Programa Cultura Viva. Brasília: Ipea, 2013. Vídeo Youtube, son., color. Série Panorama Ipea. Entrevista com Frederico Barbosa - Ipea, e Marcia Rollemberg SCDC/MinC. Entrevistador: Pedro Cavalcanti. Entrevista publicada em 22/01/2013.. Disponível em: <https://youtu.be/owh6FT1PWvg?list=PLub5u0sqoSu7N8No2YS0GCifTrBExkxA>. Acesso em: 28 jan. 2016.

REDESENHO do Programa Cultura Viva. Brasília: Ipea, 2015. Vídeo Youtube, son., color. Série Panorama Ipea. Entrevista com Frederico Barbosa - Ipea, e Marcia Rollemberg SCDC/MinC. Entrevistadora: Manaíra Lacerda. Entrevista publicada em 15/01/2015. Disponível em: <https://youtu.be/tQRI7tQHH1g?list=PLub5u0sqoSu7N8No2YS0GCifTrBExkxA>. Acesso em: 28 jan. 2016.

ROLlEMBERG, Marcia. Política Nacional de Cultura Viva: Desafios e Prioridades. In: ENCONTRO BRASILEIRO DE PESQUISA EM CULTURA, 2., 2014, Rio de Janeiro. Artigo. S. L.: Uff, 2014. p. 1 - 19. Disponível em: <https://www.google.com.br/search?q=política+nacional+de+cultura+viva+desafios+e+ 
prioridades+rollembe>. Acesso em: 04 fev. 2016.

ROLLEMBERG, Marcia. Cidadania e Diversidade Cultural com Participação Social. Artigo apresentado no V Seminário Internacional - Políticas Culturais - 7-9 de março de 2014. Rio de Janeiro: Fundação Casa de Rui Barbosa. Disponível em: http://culturadigital.br/politicaculturalcasaderuibarbosa/files/2014/06/MarciaRollemberg.pdf

RUBIM, Albino. Políticas Culturais entre o possível e o impossível. Comunicação apresentada no II Encontro de Estudos Multidisciplinares em Cultura (Enecult). Salvador: FACOM/UFBA, 2006.

SANTOS, Boaventura de Sousa. Pela mão de Alice: o social e o político na pósmodernidade. Porto: Edições Afrontamento, $7^{\text {a }}$ edição, 1999.

Conocer desde el Sur. Para uma cultura política emancipatória. Lima: Fondo Editorial de la Facultad de Ciencias Sociales de la Universidad Mayor de San Marcos, 2006.

Boitempo, 2007.

SEMINÁRIO INTERNACIONAL DO PROGRAMA CULTURA VIVA, 2009, Pirenópolis / Go - Brasil. Programa Cultura Viva: Análises e observações. Brasília: Ministério da Cultura, 2010. 109 p.

SEN, Amartya. Desenvolvimento como Liberdade. São Paulo: Companhia das Letras, 2010.

SOUZA, Celina. Capacidade Burocrática no Brasil e na Argentina: quando a política faz a diferença. In: GOMIDE, Alexandre de Ávila; BOSCHI, Renato Raul (Ed.). Capacidades estatais em países emergentes: o Brasil em perspectiva comparada. Rio de Janeiro: Ipea, 2016. Cap. 2. p. 51-103. Disponível em: <http://www.ipea.gov.br/portal/images/stories/PDFs/livros/livro_capacidades.pdf >. Acesso em: 29 mar. 2016.

UNESCO. Dez Chaves para entender a Convenção para a Proteção e a Promoção da Diversidade das Expressões Culturais [adotada pela 33a Sessão da Conferência Geral da Unesco em 2005. Brasília: Unesco (Brochura sem data).

VARELlA, Guilherme. Plano Nacional de Cultura: Direitos e Políticas Culturais no Brasil. Rio de Janeiro: Azougue, 2014. 208 p. 


\section{LISTA DAS ENTREVISTAS REALIZADAS}

Entrevista I [julho 2015]. Entrevistador: Bruno H. R. Melo. Buenos Aires, 2015. 1 arquivo .wav (88 min.). O áudio e a transcrição da entrevista na íntegra encontram-se sob a guarda do entrevistador. Entrevistado: L.F., Coordenadora da área técnico-administrativa do programa Puntos de Cultura, Ministério da Cultura, Argentina.

Entrevista II [julho 2015]. Entrevistador: Bruno H. R. Melo. Buenos Aires, 2015. 1 arquivo .wav (70 min.). O áudio da entrevista na íntegra encontra-se sob a guarda do entrevistador. Entrevistado: D.B., Coordenador do programa Puntos de Cultura, Ministério da Cultura, Argentina.

Entrevista III [julho 2015]. Entrevistador: Bruno H. R. Melo. Buenos Aires, 2015. 1 arquivo .wav (61 min.). O áudio da entrevista na íntegra encontra-se sob a guarda do entrevistador. Entrevistado: E.G., Responsável regional do programa Puntos de Cultura, Ministério da Cultura, Argentina.

Entrevista IV [julho 2015]. Entrevistador: Bruno H. R. Melo. Buenos Aires, 2015. 1 arquivo .wav (27 min.). O áudio e a transcrição da entrevista na íntegra encontram-se sob a guarda do entrevistador. Entrevistado: M.V.A., Diretora da área de Políticas Sócioculturais, Ministério da Cultura, Argentina.

Entrevista V [julho 2015]. Entrevistador: Bruno H. R. Melo. Buenos Aires, 2015. 1 arquivo .m4a (32 min.). $\mathrm{O}$ audio parcial da entrevista encontra-se sob a guarda do entrevistador. Entrevistado: M.R.P., Gestora de Punto de Cultura, Argentina.

Entrevista VI [julho 2015]. Entrevistador: Bruno H. R. Melo. Buenos Aires, 2015. Áudio não disponível. Notas da entrevista encontram-se sob a guarda do entrevistador. Entrevistado: vários., gestores e participantes de Punto de Cultura, Argentina.

Entrevista VII [fevereiro 2016]. Entrevistador: Bruno H. R. Melo. Brasília, 2016. 1 arquivo .wav (41 min.). O áudio da entrevista na íntegra encontra-se sob a guarda do entrevistador. Entrevistado: A.S., Diretor de programa, SCDC, Ministério da Cultura, Brasil.

Entrevista VIII [março 2016]. Entrevistador: Bruno H. R. Melo. Brasília, 2016. 1 arquivo .wav (50 min.). O áudio da entrevista na íntegra encontra-se sob a guarda do entrevistador. Entrevistado: C.S., Gestora da SCDC, Ministério da Cultura, Brasil.

Entrevista IX [março 2016]. Entrevistador: Bruno H. R. Melo. Brasília, 2016. Áudio não disponível. Notas da entrevista encontram-se sob a guarda do entrevistador. Entrevistado: I.A., CoordenadoraGeral, área técnica SCDC, Ministério da Cultura, Brasil. 
ANEXOS 


\section{QUESTIONÁRIO PARA ENTREVISTAS COM GESTORES}

\section{DIREITOS CULTURAIS, CIDADANIA E PARTICIPAÇÃO SOCIAL}

1- Qual a sua percepção sobre esses conceitos?

2- Esses conceitos estão presentes nas políticas nacionais de cultura do seu país?

3- Como esses conceitos se concretizam nas políticas culturais de base comunitária do Brasil (Argentina)?

\section{DESENVOLVIMENTO E POLÍTICAS CULTURAIS}

4- Você considera o Programa Cultura Viva (Brasil) / Puntos de Cultura (Argentina) como parte da política de desenvolvimento do seu país?

\section{O PROGRAMA “PUNTOS DE CULTURA” (AR) / CULTURA VIVA (BR)}

5- Como funciona o programa?
a. Quais são os principais atores envolvidos nesse programa?
b. Como eles interagem entre si e com o programa?
c. Como se dá a mobilização para convocatórias e eventos?
d. Existem mecanismos para garantir continuidade/sustentabilidade das ações?

6- Qual os principais instrumentos de gestão utilizados pelo Estado no programa?

a. Quais os desafios enfrentados?

b. Quais as soluções encontradas/vislumbradas?

7- Você considera que os instrumentos utilizados permitem a plena realização da cidadania, dos direitos culturais e da participação social? Por quê?

8- Quais os principais avanços (ou retrocessos) na implementação desse programa?

\section{RESULTADOS DO PROGRAMA}

9- Houve alguma mudança na relação entre os Pontos de Cultura e o Estado (governo) durante a implementação do programa?

a. Como você representaria essa mudança?

b. Como você enxerga essa relação no futuro?

10-Seria possível afirmar que a escolha desses instrumentos ou práticas influencia o resultado da sua ação e do programa como um todo? 


\section{Critérios da AutodeclaraÇão}

A autodeclaração de entidades e coletivos culturais como Pontos ou Pontões de Cultura é uma iniciativa da sociedade civil, e cabe ao Ministério da Cultura, estados e municípios oferecerem estímulo, apoio e instrumentos para que, a partir desta iniciativa de autodeclaração, as entidades e coletivos possam ser certificados e reconhecidos como Pontos ou Pontões de Cultura, conforme previsto na Lei Cultura Viva e em sua regulamentação.

A plataforma Rede Cultura Viva é a interface digital do Cadastro Nacional dos Pontos e Pontões de Cultura, instrumento previsto na Lei Cultura Viva, conforme disposto no Inciso III do artigo 4 desta lei:

"III - Cadastro Nacional de Pontos e Pontões de Cultura: integrado pelos grupos, coletivos e pessoas jurídicas de direito privado sem fins lucrativos que desenvolvam ações culturais e que possuam certificação simplificada concedida pelo Ministério da Cultura."

A Certificação Simplificada como Ponto ou Pontão de Cultura, através da Plataforma Rede Cultura Viva, será um processo seletivo simplificado, aberto permanentemente em fluxo contínuo, destinado ao reconhecimento de entidades e coletivos culturais como Pontos ou Pontões de Cultura. As propostas de certificação enviadas serão analisadas por uma comissão paritária composta por membros do poder público e da sociedade civil. A análise será realizada com base nos seguintes critérios, alinhados às diretrizes e normativos da Politica Nacional de Cultura Viva:

\section{Critérios:}

I - Ser pessoa jurídica de direito privado sem fins lucrativos, ou coletivo cultural sem constituição jurídica, de natureza ou finalidade cultural, que desenvolva e articule atividades culturais em suas comunidades;

II - Comprove, no mínimo, 1 (um) ano de existência e desenvolvimento de atividade culturais, através de fotos, material gráfico de eventos, publicações impressas e em meios eletrônicos e outros materiais comprobatórios;

III - Que tenha o apoio, por meio de cartas de reconhecimento, de no minimo 2 (dois) Pontos de Cultura, instituições públicas, privadas, coletivos culturais ou comunidades, com ou sem constituição jurídica, relacionados à arte, cultura, educação ou desenvolvimento comunitário. As cartas devem ser assinadas e digitalizadas. Serão aceitas somente assinaturas manuscritas em papel ou impressões digitais em caso de pessoas não alfabetizadas. Não serão aceitas assinaturas digitais.

IV - Preencha as informações de Cadastro na Plataforma Rede Cultura Viva e aceite os Termos de Uso e o Termo de Adesão à Política Nacional de Cultura Viva.

Para chegarmos aos 15 mil Pontos de Cultura fomentados em 2020, conforme previsto nas metas do Plano Nacional de Cultura, é preciso ampla mobilização da sociedade, e cabe ao Ministério da Cultura promover condições para mapear, reconhecer, dar visibilidade e promover intercâmbios e trocas em rede entre estas iniciativas culturais de todo o país.

A aprovação da Lei Cultura Viva foi uma conquista da sociedade, e os pontos de cultura são uma experiência de política cultural reconhecida nacional e internacionalmente. O reconhecimento de entidades e coletivos culturais como pontos de cultura através da auto-declaração será fundamental para ampliar a escala, dar visibilidade e democratizar ainda mais esta experiência, alcançando os mais diversos segmentos da diversidade cultural brasileira.

Fonte: SCDC/MinC/Brasil - http://culturaviva.gov.br/criterios-da-autodeclaracao/ Acesso em 05/04/2016. 